Article

\title{
Possible Involvement of Permian Phosphoria Formation Oil as a Source of REE and Other Metals Associated with Complex U-V Mineralization in the Northern Bighorn Basin?
}

\author{
Anita L. Moore-Nall ${ }^{1, *,+}$ and Ranalda L. Tsosie ${ }^{2, \dagger}$ \\ 1 Department of Earth Sciences, Montana State University, P.O. Box 173480, Bozeman, MT 59717, USA \\ 2 Department of Chemistry and Biochemistry, University of Montana, 32 Campus Drive, Missoula, MT 59812, \\ USA; ranalda.tsosie@umontana.edu \\ * Correspondence: amoorenall@yahoo.com \\ + These authors contributed equally to this work.
}

Received: 15 August 2017; Accepted: 14 November 2017; Published: 23 November 2017

\begin{abstract}
The origin of V, U, REE and other metals in the Permian Phosphoria Formation have been speculated and studied by numerous scientists. The exceptionally high concentrations of metals have been interpreted to reflect fundamental transitions from anoxic to oxic marine conditions. Much of the oil in the Bighorn Basin, is sourced by the Phosphoria Formation. Two of the top 10 producing oil fields in Wyoming are located approximately $50 \mathrm{~km}$ west of two abandoned U-V mining districts in the northern portion of the basin. These fields produce from basin margin anticlinal structures from Mississippian age reservoir rock. Samples collected from abandoned U-V mines and prospects hosted in Mississippian aged paleokarst in Montana and Wyoming have hydrocarbon residue present and contain anomalous high concentrations of many metals that are found in similar concentrations in the Phosphoria Formation. As, $\mathrm{Hg}, \mathrm{Mo}, \mathrm{Pb}, \mathrm{Tl}, \mathrm{U}, \mathrm{V}$ and $\mathrm{Zn}$, often metals of environmental concern occur in high concentrations in Phosphoria Formation samples and had values ranging from 30-1295 ppm As, 0.179-12.8 ppm Hg, 2-791 ppm Mo, <2-146 ppm Pb, 10-490 ppm Tl, 907-86,800 ppm U, 1240-18,900 ppm V, and 7-2230 ppm Zn, in mineralized samples from this study. The REE plus $Y$ composition of Madison Limestone- and limestone breccia hosted-bitumen reflect similar patterns to both mineralized samples from this study and to U.S. Geological Survey rock samples from studies of the Phosphoria Formation. Geochemical, mineralogical and field data were used to investigate past theories for mineralization of these deposits to determine if $\mathrm{U}$ present in home wells and $\mathrm{Hg}$ content of fish from rivers on the proximal Crow Indian Reservation may have been derived from these deposits or related to their mode of mineralization.
\end{abstract}

Keywords: U; V; As; Hg; Mo; Pb; Tl; Zn; REE; Permian Phosphoria Formation; abandoned mines; Pryor Mountains; Bighorn Basin; silica polyamine composites; SPCs

\section{Introduction}

The original impetus for this study was to try and determine the source of $\mathrm{Hg}$ and $\mathrm{Pb}$ in the Bighorn River. The Bighorn River is listed as a 303d impaired water body downstream of the Crow Indian Reservation due to elevated $\mathrm{Pb}$ and $\mathrm{Hg}$ and the source of contamination is unknown [1]. In a 2015 United States Geological Survey (USGS) study, fish tissue from the Bighorn Reservoir had the highest $\mathrm{Hg}$ levels observed in the entire Yellowstone River Basin (0.676 $\mu \mathrm{g} / \mathrm{g}$ wet weight) [2]. The Bighorn River and its tributaries drain both the Pryor Mountain U-V Mining District (PMD), Montana (MT) and the Little Mountain U-V Mining District (LMD), Wyoming (WY) (Figure 1). 


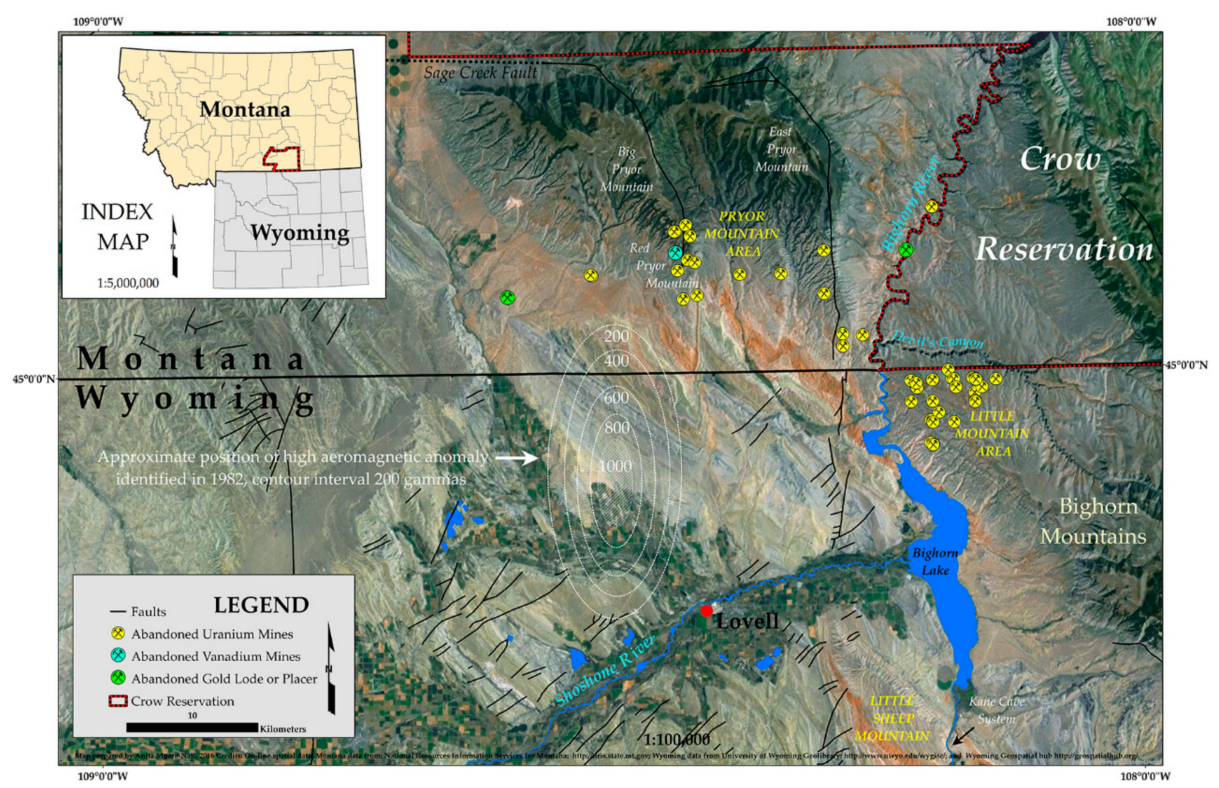

Figure 1. Map showing the location of the Pryor Mountain and the Little Mountain areas in southcentral Montana (MT) and northcentral Wyoming (WY). The yellow symbols represent abandoned U-V mines. The southern portion of the Crow Reservation, outlined by the red and black line, borders the Little Mountain U-V Mining District (LMD). The Bighorn River is superimposed across Little Sheep Mountain, WY, shown at the bottom of the map. The river flows north through WY between the two mining districts and then northeast through MT, there forming the southwest border of the Crow Indian Reservation. Approximate location of high aeromagnetic anomaly identified in 1982 described in text is shown with dashed lines to southwest of Red Pryor Mountain.

Early in the study USGS National Uranium Resource Evaluation data was reviewed. Based on the data, wells on the Crow Reservation were tested for $U$. Testing revealed that $U$ is a health risk in about 6 percent of home wells [3]. Thus, this study evolved to test theories proposed for mineralization in the two districts to see if $\mathrm{U}$ present in home wells and $\mathrm{Hg}$ detected in fish from the Bighorn Reservoir and from rivers of the Crow Reservation [2,4] might have been derived from erosion of these deposits or possibly related to the mode of mineralization. Also as a result of the $U$ findings, collaborative research related to $U$ contaminated drinking water on the Navajo and Crow Indian reservations is being conducted at the University of Montana, University of New Mexico and Montana State University. Part of this research is developing silica polyamine composites to aid in removal of $U$ and other toxic metals from contaminated drinking water.

This paper will look at mineralogical and geochemical data from samples collected in the abandoned U-V mining districts, bitumen collected from the river cut at Little Sheep Mountain and archival Phosphoria Formation sample data to understand what processes may be contributing metals to the hydrologic environment.

\section{Production History and Theories for Origin of Deposits}

Uranium was discovered in the Pryor Mountains, MT (Figure 1) in September 1955 and several months later in the northern Bighorn Mountains, WY [5-9]; subsequently, both $U$ and V were mined. Mines produced U-V ore from underground operations in both mining districts. Some mining was by open pit in the LMD [6]. Most production occurred in the districts from 1955-1959, after the Atomic Energy Commission opened a U buying station in Riverton, WY [5]. This station closed in the mid 1960's [4]. Some mining continued until 1970 in the LMD [10] and until 1974 in the PMD [10]. The primary ore minerals in the two U-V mining districts are the Ca-uranyl vanadates tyuyamunite $\left(\mathrm{Ca}\left(\mathrm{UO}_{2}\right)_{2}\left(\mathrm{VO}_{4}\right)_{2} \cdot 5-8 \mathrm{H}_{2} \mathrm{O}\right)$ and metatyuyamunite $\left(\mathrm{Ca}\left(\mathrm{UO}_{2}\right)_{2}\left(\mathrm{VO}_{4}\right)_{2} \cdot 3-5 \mathrm{H}_{2} \mathrm{O}\right)[5,6,10-12]$ which are 
usually secondary minerals in most $\mathrm{U}$ deposits. These deposits are hosted in Mississippian Madison Group $(\mathrm{Mm})$ Limestone and collapse paleokarst. The relatively small, high-grade (median grades of $0.26 \% \mathrm{U}_{3} \mathrm{O}_{8}, 0.23 \% \mathrm{~V}_{2} \mathrm{O}_{5}$ ) deposits in MT and $\mathrm{WY}$ combined, produced 133,810 $\mathrm{kg}$ triuranium octoxide $\left(\mathrm{U}_{3} \mathrm{O}_{8}\right)$ and $106,594 \mathrm{~kg}$ of vanadium oxide $\left(\mathrm{V}_{2} \mathrm{O}_{5}\right)$ during 1956-1964 [5]. The U.S. Bureau of Land Management reclaimed ten mines in the PMD in 2006 [13]. They removed ore for reprocessing and re-graded waste rock and overburden to discourage recreational use on the piles. Mine entrances were closed and some of them were fitted with bat gates to maintain bat populations [13]. The LMD is closed to the public for safety.

Two main alternate sources for the $\mathrm{U}$ and $\mathrm{V}$ have been postulated in the districts: (1) ascending hydrothermal (magmatic) fluids traveling up faults and fracture zones and anticlinal structures $[5,6,14,15]$ or (2) meteoric waters, principally groundwater, that flushed through the breccia-filled caverns during the Cenozoic with the $U$ being leached from tuffaceous material or ash that once covered the region during the Tertiary [5,6,11]. Support for the first idea includes: (1) petrographic identification of davidite $\left[\left(\mathrm{Fe}^{+2}, \mathrm{La}, \mathrm{U}, \mathrm{Ca}\right)_{6}\left(\mathrm{Ti}_{1}, \mathrm{Fe}^{+3}\right)_{15}(\mathrm{O}, \mathrm{OH})_{36}\right]$, a high temperature U-REE oxide mineral and associated fluorite [14,15]; (2) In 1982, the U.S. Department of Energy identified a N-S trending, $30 \mathrm{~km}$ long magnetic high anomaly located to the SW of the Big Pryor Mountain block $[5,6,16]$. The estimated depth of $3-3.6 \mathrm{~km}$ to the anomaly suggests the buried magnetic body occurs at or near the top of the Precambrian basement [6]. An inferred intrusion, a potential source of the magnetic anomaly (Figure 1) could provide ascending hydrothermal fluids and a heat source for the MT/WY deposits $[5,6,16]$. An intrusion may also account for the abandoned gold workings to the west of Big Pryor Mountain and silicification in the PMD. Problems with this theory are: (1) the apparent absence of significant radioactivity within the larger faults and fractures of the two districts; (2) the restriction of U-V minerals primarily to the cavern fill and nearby fractures in country rocks; (3) the unaltered character of the limestone outside the host caverns; and (4) the possibility that the identified davidite is a detrital mineral derived from the erosion of Precambrian rocks [5].

Support for the second theory include: (1) The well-developed liesegang banding at some deposits in the PMD, indicating that considerable fluid flow (whether meteoric or hydrothermal in origin) passed through the cavern fill and adjacent wall rocks; (2) Abundant bentonite beds in the Bighorn Basin of Eocene, Oligocene, and Miocene age are possible sources for the uranium [5,6]; and (3) The deposits generally occur along previous routes for major drainages of the Bighorn Basin [5-7]. Problems with the theory are the lack of explanations for the silicification, fluorite and barite that are present in the PMD but not in the LMD. The abundance of caves [11,17], may support a hypogenic karst origin. Support for this model is the nearby Kane Cave system in the Little Sheep Mountain anticline, WY. The Lower Kane cave, hosted in Mississippian-age Madison Group limestone in the core of the anticline, is actively forming by hypogenic sulfuric acid speleogenesis, at the level of the Bighorn River $[18,19]$. The cave contains radioactive mud and water with $\mathrm{U}, \mathrm{V}, \mathrm{Pb}$, other metals, hydrogen sulfide gas, and a microbial community of Fe and sulfate reducing bacteria [18]. Potential V sources are the Permian Park City Formation (Phosphoria Formation equivalent in MT) [20-22] or V-rich, Phosphoria Formation-sourced oil from the Bighorn Basin [23,24].

\section{Study Areas}

\subsection{Physiography}

The study area lies along the eastern side of the Middle Rocky Mountain Physiographic Province in the northeast margin of the Bighorn Basin. The study area includes the two mining districts and the river cut area of Little Sheep Mountain. The Bighorn Basin is a structural basin bounded by the Big Horn Mountains to the east, the Owl Creek/Bridger Mountains to the south, the Absaroka and Beartooth Mountains to the west and the Pryor Mountains to the north. The areal extent of the basin is approximately $25,900 \mathrm{~km}^{2}$ within the outcrop of upper Cretaceous rock exposed in the basin $[25,26]$. 


\subsection{Stratigraphy}

Rocks in the region range from Archean to Quaternary in age (Figure 2). Approximately 760-915 $m$ of Paleozoic rock overlie Archean gneiss and schist in the study areas [27]. The main formations of exposure relevant to the $\mathrm{U}-\mathrm{V}$ deposits in the mining districts include limestones and dolomites of the Mississippian Madison Group (Madison Formation in WY). Extensive regional paleokarst features at the top of the Madison Group locally host collapse breccia [28,29], which are host structures of the U-V deposits $[5,6,10,11]$. The horizon is characterized by solution cavities along bedding planes, fractures and joints, and collapse breccia filled with angular limestone fragments of variable size (from several $\mathrm{cm}$ to several meters across) and reddish clay silt from the overlying Amsden Formation [6]. The in filling with Amsden Formation imparts a red to purple matrix to many of the breccia units.

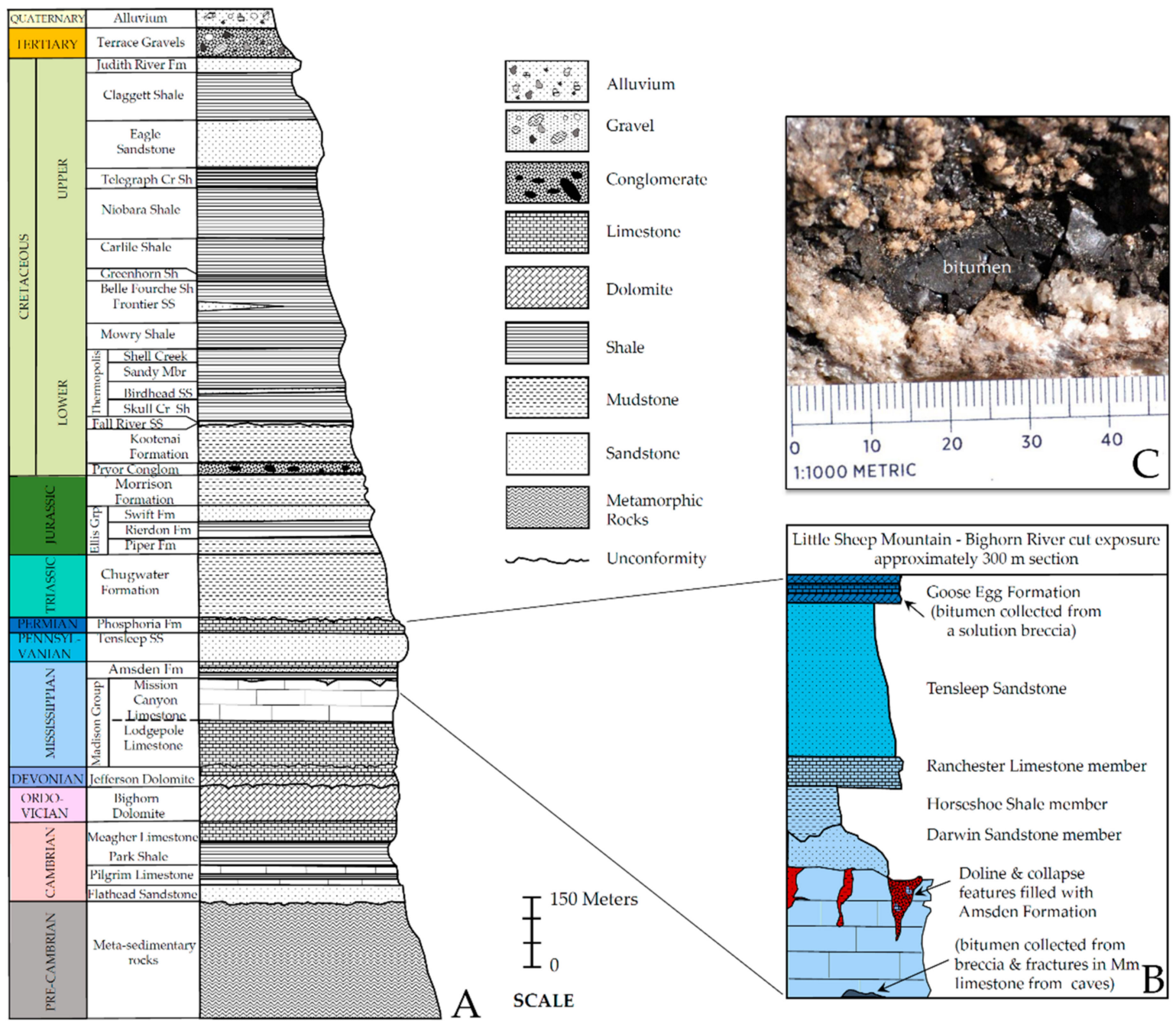

Figure 2. (A) Generalized stratigraphic column of the Pryor Mountain area, MT, modified from Lopez [30]; (B) Generalized stratigraphic column of the river cut exposure in Little Sheep Mountain anticline is shown to the right with arrows indicating stratigraphic position of bitumen collection sites for this study; (C) Bitumen collected in Madison limestone breccia from upper Kane Cave, Little Sheep Mountain, WY.

\subsection{Structural Setting}

During the Laramide Orogeny (80-35 Ma), the central Rocky Mountain region experienced a general NE-SW $\left(40^{\circ}-55^{\circ}\right)$ transpressional strain regime as a result of the low-angle subduction of the Farallon plate at its western continental margin [31,32]. Beginning in the late Cretaceous, 
Laramide shortening was accommodated by uplift of broad basement arches that eventually isolated the Bighorn Basin (Figure 3) [31]. The Bighorn Basin has a generally NW-SE sinuous axis [26]. Smaller scale folds in the form of anticlines and synclines formed along the basin margins and served to accommodate regional shortening [31-33]. These folds host most of the oil fields of the Bighorn Basin [34]. The structures hosting the U-V mining districts and the Little Sheep Mountain anticline are all folds created during this time. Structurally the Pryor Mountains are divided into N and S segments by the Sage Creek fault zone, the eastern extension of the Nye-Bowler lineament. The lineament is interpreted to be the expression of a left-lateral wrench fault at depth and defines the northern end of the Bighorn Basin $[26,34,35]$. The U-V deposits in the PMD occur in the southern portion of the Pryor Mountains, MT.

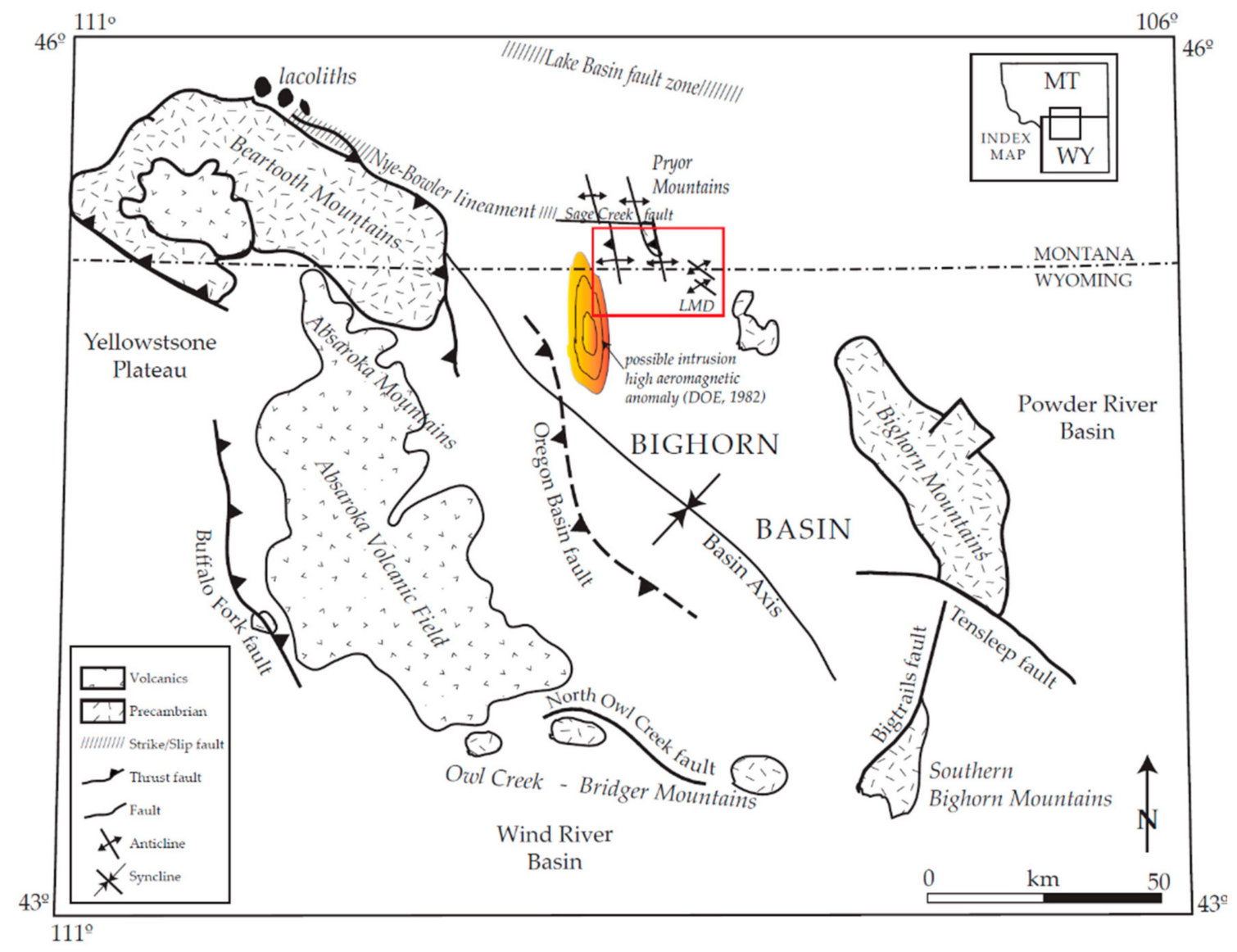

Figure 3. Map showing the tectonic features of the Bighorn Basin (BHB). Precambrian cored arches and volcanics are represented by stippled patterns. The Lake Basin fault zone, volcanic domes (lacoliths) of the Nye-Bowler lineament, Sage Creek fault zone are shown in the top portion of the figure. The location of the mining districts is outlined by the red rectangle. Map modified from Blackstone [26] and Stahl [36].

\subsection{Mineralization and Alteration}

The main difference in the ore of the two districts is the silica content. The silica content of the PMD was high and the LMD was low $[5,6,11]$. Abundant silica observed in the PMD is concentrated in and around siliceous tectonic hydrothermal breccia (THB). These were emplaced in fractures along the crest of the Gypsum Creek anticline which forms the southern portion of the Big Pryor Mountain block (Figure 1). The U-V ore minerals of MT/WY are easy to recognize in outcrop due to their bright yellow color (Figure 4A-G). Boxwork is common in both districts (Figure 4H,I). At many of the deposits, the host rock appears fresh and unaltered within a few feet of the mineralization. The wall rock in 
the PMD has the most alteration of the three areas studied including bleaching, liesegang banding, silicification, hematite-, and limonite-staining.
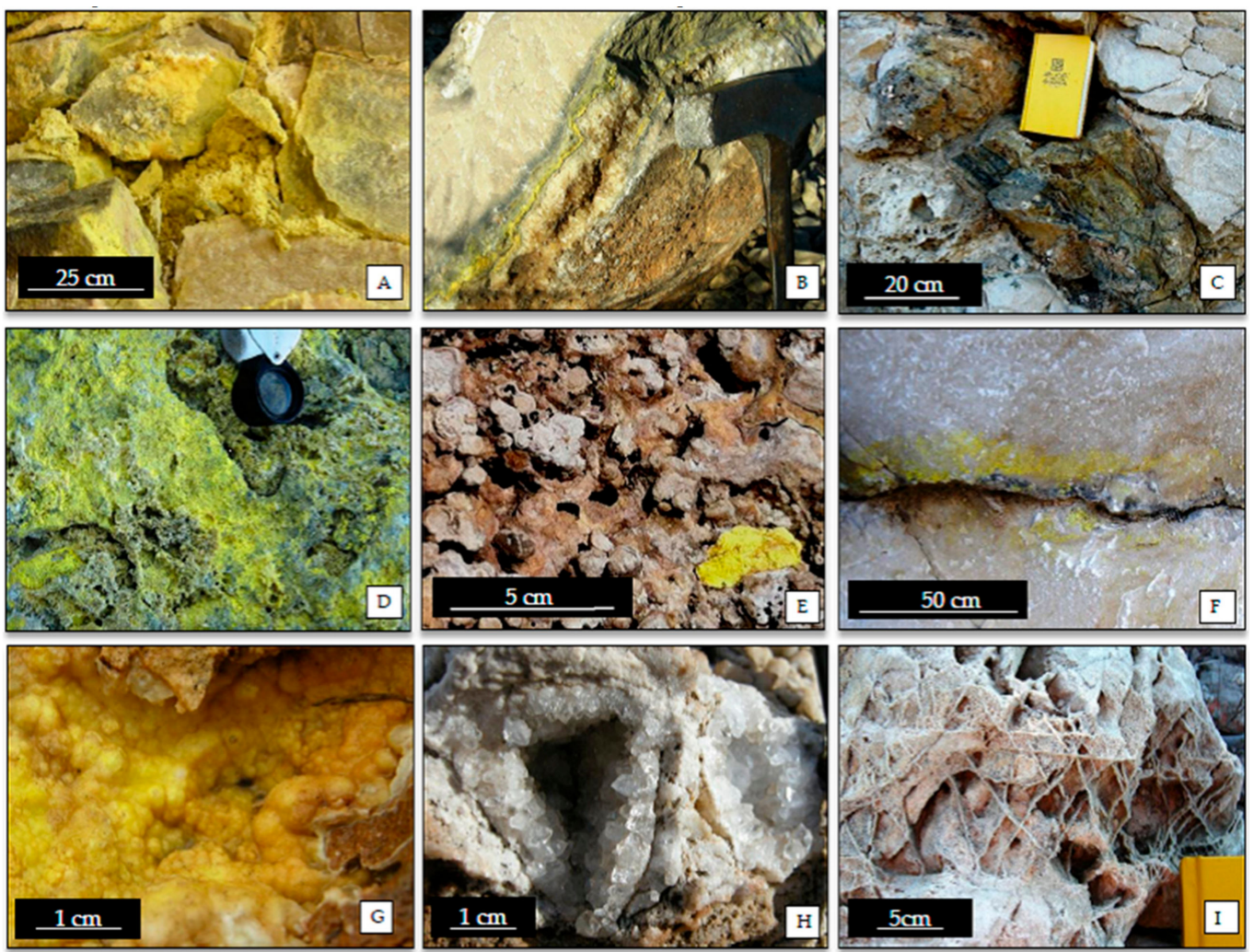

Figure 4. Outcrop photos of U-V mineral occurrences and boxwork the MT/WY deposits: (A) Silt-size and powdery coatings, Pryor Mountain U-V Mining District (PMD); (B) Boulder with U-V minerals lining fractures filled with calcite, LMD; (C) Fracture hosted tectonic hydrothermal breccia (THB) with boxwork formed in host limestone, LMD (D) Calcite cemented surface coatings, LMD; (E) Cave floor type occurrence, PMD; (F) U-V minerals along sprung stylolites, PMD. (G) Silica and U minerals coating breccia clasts, PMD; (H) Quartz-lined boxwork, PMD; and (I) Systematic fractures preserved as boxwork, LMD. Figure modified from Moore-Nall and Lageson [37].

\section{Tectonic Hydrothermal Breccia, PMD}

Siliceous THB only observed in the PMD, are relatively small, 0.5-5 m wide, hematite- and limonite-stained dike-like features (Figure 5A). Tectonic breccia were sampled to determine the isotope markers (stable $\mathrm{C}, \mathrm{O}$ and radiogenic $\mathrm{Sr}$ ) [37]. Although bleaching does not extend far from the THB, the wall rock is generally bleached where the breccia cut through. Wall rock around some of the features is liesegang banded (Figure 5B). The matrices of the THB are composed of cryptocrystalline silica and local microscopic Fe-oxide inclusions. Unmineralized THB have barite, local fluorite, minor oxides, and sulfides along fracture surfaces and in vugs. The mineralized THB have U-V minerals filling in vugs and fractures in addition to the other minerals. 

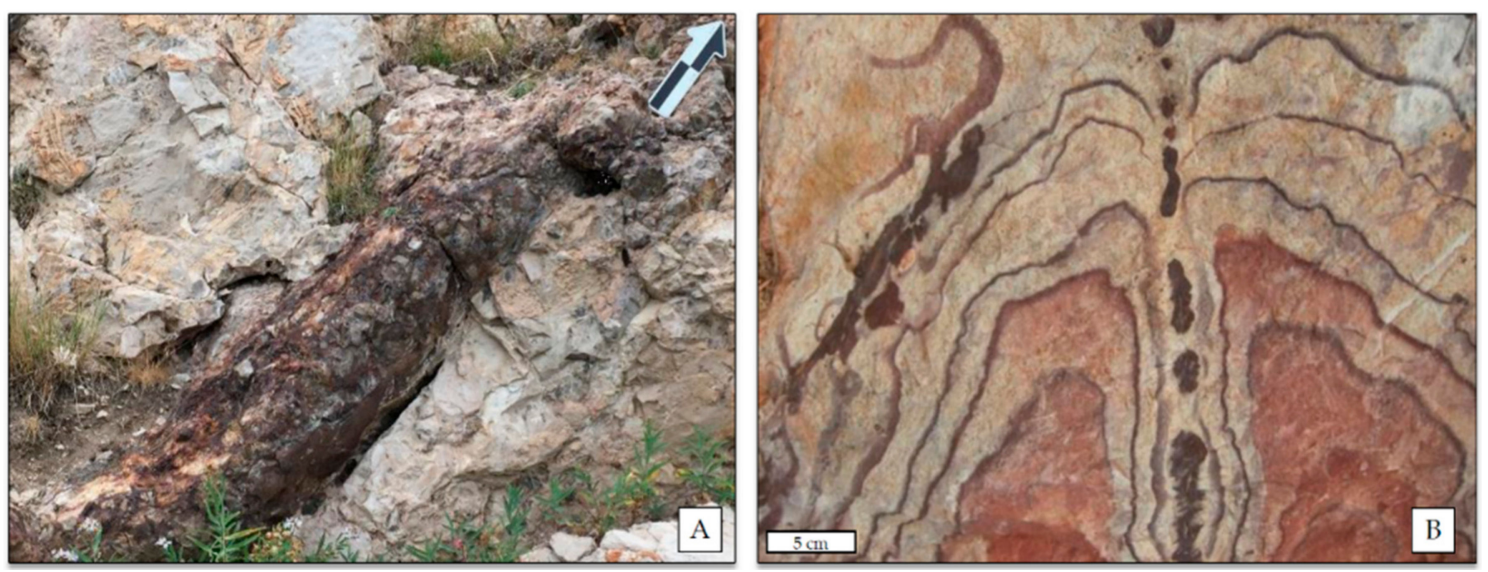

Figure 5. (A) Mineralized hematite- and limonite-stained, silicified THB cuts through bleached collapse paleokarst breccia along a fracture, Sandra mine area, PMD, $20 \mathrm{~cm}$ arrow for scale; (B) Liesegang banding developed in lower Amsden Formation adjacent to the Old Glory mine, PMD.

\section{Methods}

\subsection{Field Work}

Samples were chosen to test theories proposed for the origin of these deposits. A Thermo Scientific ${ }^{\mathrm{TM}}$ RadEye ${ }^{\mathrm{TM}}$ Personal Radiation Detector (Thermo Fisher Scientific Inc., Erlangen, Germany) was used to identify elevated radiation sources in the field. Rock samples included breccia clasts and matrix samples, altered and unaltered host rock, generations of cements from veins, and mineralized samples from dumps and outcrops. A bentonite sample was collected from an operating bentonite mine approximately $20 \mathrm{~km}$ southeast of the LMD to use to test the theory that $\mathrm{U}$ leached from volcanic ash that once covered the region. Dried bitumen was collected from fractures in Mm limestone and limestone breccia in two caves as well as from fractures in a limestone solution breccia in the Permian Goose Egg Formation exposed in the river cut of Little Sheep Mountain (Figure 1). The bitumen samples were collected to compare the REE and Y composition of our U-V mineralized samples to test the hydrothermal theory, which is an association with oil and brines from the BHB. Two speleothem calcite samples from Big Pryor Mountain were collected to compare REE and assay analyses with calcite cement of breccia samples and calcite fracture fill to test the meteoric theory.

\subsection{Mineralogical and Geochemical Characterization}

Work performed to complete analyses included: standard petrography, cathodoluminescence (CL), scanning electron microscopy (SEM) utilizing energy dispersive X-ray spectrometry (EDS) and backscatter electron imaging (BSE), powder X-ray diffraction (XRD) spectroscopy and minor fluid inclusion work. Most of the analytical work was performed using instrumentation in the Imaging and Chemical Analysis Laboratory (ICAL) facility at Montana State University (MSU), Bozeman, MT, USA. XRD work was performed on a SCINTAG X1 Diffraction Spectrometer (Scintag Inc., West Palm Beach, FL, USA) and computer-aided mineral identification system at ICAL. SEM work was conducted at ICAL using a JEOL JSM-6100 (JEOL USA Inc., Peabody, MA, USA). CL was performed at the Department of Earth Sciences (Montana State University, Bozeman, MT, USA) using a RELIOTRON CL luminoscope instrument (RELION Industries LLC, Bedford, MA, USA) attached to a Nikon microscope (Nikon Corporation, Tokyo, Japan). Assays were performed by two different commercial laboratories: American Analytical Services (AAS) Inc., in Osborn, ID, USA and an Australian Laboratory Services (ALS) Global branch out of Reno, NV, USA. 
Sample Preparation

Samples were prepared for chemical assay and REE analyses at MSU. Most samples were broken into chips and then pulverized in a Plattner's diamond mortar and pestle set while a few required micro drilling with a diamond tipped dremel bit. Some of the samples for REE analysis were pulverized in a shatter box. The mineralized U-V breccia were selected to try to get mainly the yellow U-V minerals, samples included part of the breccia host as the U-V minerals were disseminated throughout the samples. Fluorite was microdrilled. Barite was collected as individual crystals in the field and pulverized at MSU. Thin sections and some hand samples were stained for carbonate identification using a mixture of alizarin red and potassium cyanide solution [38].

\section{Results, Mineralogy and Geochemistry}

Samples examined by multiple methods revealed the episodic nature of mineralization in both districts. Bitumen was observed at all scales in this study; in outcrop along fractures and bedding planes, petrographically in interparticle porosity, and as inclusions in cement and minerals. Oxides, hydroxides and sulfides were closely associated with U-V minerals in both districts. The white card petrographic method, placing a piece of white paper beneath a petrographic slide, differentiated bitumen from sulfides and oxides [39]. It was also useful for viewing U-V minerals. CL revealed zoning in carbonates, fluorites, and highlighted U-V minerals and Fe-V oxides. The EDS and BSE modes of the SEM revealed compositional variations in minerals. The Secondary Electron Image (SEI) mode of the SEM aided in viewing morphology of minerals with the same composition. BSE mode discriminates between different phases as a function of the mean atomic number [40]. Minerals with larger $\mathrm{Z}$ appear brighter than lighter ones. This mode was useful for seeing zonation in some of the sulfides and for identifying elements present in minerals. Portable XRF and EDS detected Au (Appendix A, Figure A1) and platinum group metals (PGM) in some of the samples. A few samples were sent in for assays for these elements (Table A1). Data from both commercial labs is shown in Appendix A. Some results of the above techniques are presented in figures in Appendix B.

\subsection{Mineralogy: Ore and Gangue Minerals}

\subsubsection{Ore Minerals}

Ore and gangue minerals reported in the literature and new minerals identified in this study are shown in Table 1.

Table 1. Ore and gangue minerals reported in the literature and identified in this study for the Pryor Mountain and Little Mountain mining districts of Montana and Wyoming.

\begin{tabular}{|c|c|c|c|}
\hline \multicolumn{4}{|c|}{ Ore Minerals Reported in the Districts, ${ }^{*}$ PMD Only } \\
\hline \multicolumn{2}{|c|}{ uranyl-vanadates } & \multicolumn{2}{|c|}{ uranyl (silicate, carbonate, phosphate) } \\
\hline \multicolumn{2}{|c|}{$\begin{array}{l}\text { metatyuyamunite } \mathrm{Ca}\left(\mathrm{UO}_{2}\right)_{2}\left(\mathrm{VO}_{4}\right)_{2} \cdot 3-5 \mathrm{H}_{2} \mathrm{O}[5-7,10,11,14] \\
\text { tyuyamunite } \mathrm{Ca}\left(\mathrm{UO}_{2}\right)_{2}\left(\mathrm{VO}_{4}\right)_{2} \cdot 5-8 \mathrm{H}_{2} \mathrm{O}[5-7,10,11,14] \\
\text { *francevillite } \mathrm{Ba}\left(\mathrm{UO}_{2}\right)_{2}\left(\mathrm{VO}_{4}\right)_{2} \cdot 5 \mathrm{H}_{2} \mathrm{O} \text { [this study] } \\
\text { *francevillite }(\mathrm{Ba}, \mathrm{Pb})\left(\mathrm{UO}_{2}\right)_{2}\left(\mathrm{VO}_{4}\right)_{2} \cdot 5 \mathrm{H}_{2} \mathrm{O} \text { [this study [37]] } \\
\quad \text { *arnotite } \mathrm{K}_{2}\left(\mathrm{UO}_{2}\right)_{2}\left(\mathrm{VO}_{4}\right)_{2} \cdot 3 \mathrm{H}_{2} \mathrm{O} \text { [this study] } \\
\quad \text { *Unidentified Tl uranyl-vanadates [this study] }\end{array}$} & \multicolumn{2}{|c|}{$\begin{array}{c}\text { *uranophane } \mathrm{Ca}\left(\mathrm{UO}_{2}\right)_{2} \mathrm{Si}_{2} \mathrm{O}_{7} \cdot 6 \mathrm{H}_{2} \mathrm{O}[5,6] \\
\text { * green liebigite } \mathrm{Ca}_{2}\left(\mathrm{UO}_{2}\right)\left(\mathrm{CO}_{3}\right)_{3} \cdot 11 \mathrm{H}_{2} \mathrm{O}[6] \\
\text { *autunite } \mathrm{Ca}\left(\mathrm{UO}_{2}\right)_{2}\left(\mathrm{PO}_{4}\right)_{2} \cdot 10-12 \mathrm{H}_{2} \mathrm{O}[6] \\
\text { Crichtonite Group } \\
\text { *davidite }\left(\mathrm{Fe}^{+2}, \mathrm{La}, \mathrm{U}, \mathrm{Ca}\right)_{6}\left(\mathrm{Ti}_{1}, \mathrm{Fe}^{+3}\right)_{15}(\mathrm{O}, \mathrm{OH})_{36}[14]\end{array}$} \\
\hline \multicolumn{4}{|c|}{ Gangue minerals reported in the districts [5], *PMD only $[5,6,8,14,15]$} \\
\hline \multirow[t]{2}{*}{$\begin{array}{l}\text { hematite } \\
\text { limonite } \\
\text { pyrite } \\
\text { marcasite }\end{array}$} & $\begin{array}{l}\text { iron-oxides } \\
\text { iron-hydroxides } \\
\text { clay minerals } \\
\text { gypsum }\end{array}$ & $\begin{array}{c}\text { green radioactive calcite } \\
\text { dogtooth calcite } \\
\text { dolomite } \\
\text { quartz }\end{array}$ & $\begin{array}{c}\text { *celestite } \\
\text { *dark purple fluorite } \\
\text { *golden and white barite } \\
\text { *opal }\end{array}$ \\
\hline & \multicolumn{2}{|c|}{ Gangue minerals identified in this study } & *PMD only \\
\hline${ }^{*}$ witherite $\mathrm{BaCO}_{3}$ & saddle dolomite & *halloysite $\mathrm{Al}_{2}\left(\mathrm{Si}_{2} \mathrm{O}_{5}\right)(\mathrm{OH})_{4}$ & herkimer style quartz \\
\hline
\end{tabular}

The primary ore minerals in the two districts are the Ca-uranyl vanadate minerals Tyuyamunite $\left(\mathrm{Ca}\left(\mathrm{UO}_{2}\right)_{2}\left(\mathrm{VO}_{4}\right)_{2} \cdot 5-8 \mathrm{H}_{2} \mathrm{O}\right)$ and metatyuyamunite $\left(\mathrm{Ca}\left(\mathrm{UO}_{2}\right)_{2}\left(\mathrm{VO}_{4}\right)_{2} \cdot 3-5 \mathrm{H}_{2} \mathrm{O}\right)$. These were the only 
uranyl vanadates reported in the literature and were reconfirmed in both districts in this study by XRD and EDS. Two additional metal-uranyl vanadates were identified by XRD and EDS in only the PMD in this study [41]. These minerals are francevillites in the Curienite-Francevillite Series $\left(\mathrm{Pb}\left(\mathrm{UO}_{2}\right)_{2}\left(\mathrm{VO}_{4}\right)_{2} \cdot 5 \mathrm{H}_{2} \mathrm{O}\right.$ to $\left.\mathrm{Ba}\left(\mathrm{UO}_{2}\right)_{2}\left(\mathrm{VO}_{4}\right)_{2} \cdot 5 \mathrm{H}_{2} \mathrm{O}\right)$ [42]. Additionally, Carnotite, a K-uranyl vanadate $\left(\mathrm{K}_{2}\left(\mathrm{UO}_{2}\right)_{2}\left(\mathrm{VO}_{4}\right)_{2} \cdot 3 \mathrm{H}_{2} \mathrm{O}\right)$, [43], was identified only by EDS in this study in the PMD (Figure A2). U-K grains with occur locally as $2-10 \mu \mathrm{m}$ grains in dark purple fluorite (Figure A3). EDS detected thallium (Tl) in an unidentified uranyl vanadate from a prospect site, in the PMD (Figure A4). A mineral with the same morphology was found with tyuyamunite from the Dandy mine, which had the highest $\mathrm{Tl}(490 \mathrm{ppm})$ concentration of the study in analyses performed by ALS (Appendix A, Table A2). The only Tl-uranyl vanadate found in Mindat.org is thallian carnotite $(\mathrm{K}, \mathrm{Tl})_{2}\left(\mathrm{UO}_{2}\right)_{2}\left[\mathrm{VO}_{4}\right]_{2} \cdot 3 \mathrm{H}_{2} \mathrm{O}$ [44]. This mineral did not contain $\mathrm{K}$ and may be a Tl-bearing phase of curientite, with $\mathrm{Tl}$ substituting for some of the $\mathrm{Pb}$ because $\mathrm{Tl}$ and $\mathrm{Pb}$ have similar atomic and covalent radii: $\mathrm{Tl}(1.71 .6 \AA$ and $1.45 \pm 7 \AA$ ) and $\mathrm{Pb}(1.75 \AA$ and $1.46 \pm 5 \AA)$ [45]. EDS detected $\mathrm{Tl}$ in another uranyl vanadate from a sample collected from a stockpile area near the Dandy mine (Figure A5). The weight percent of the elements are similar to francevillite; the mineral may be a Tl-bearing francevillite with $\mathrm{Tl}$ substituting for $\mathrm{Pb}$.

Minerals were cross-referenced with information in the volume Reviews in Mineralogy, Uranium: Mineralogy, Geochemistry and the Environment [45] and internet sources such as Mindat.org, handbookofmineralogy.org, rruff.info and webmineral.com. The U-V minerals locally occur together. In the mines that have abundant barite, the Ba phase followed by the $(\mathrm{Ba}, \mathrm{Pb})$ phase, then the $(\mathrm{Ba}, \mathrm{Tl})$ phase of francevillite occur together with metatyuyamunite and tyuyamunite in the deposits and probably reflect the changes in available metals in the fluids sourcing the deposits. Carnotite is found only in trace amounts. Metatyuyamunite and tyuyamunite, the only uranyl vanadate minerals originally identified in the early literature make up approximately $80 \%-90 \%$ of the U-V minerals in the PMD and are the only U-V minerals identified in the LMD. All of these minerals are indistinguishable in hand sample. The Tl-bearing uranyl vanadates have similar morphologies to the francevillites observed in this study. The morphologies of some of the metal-uranyl vanadates observed in this study are shown in Figure 6.
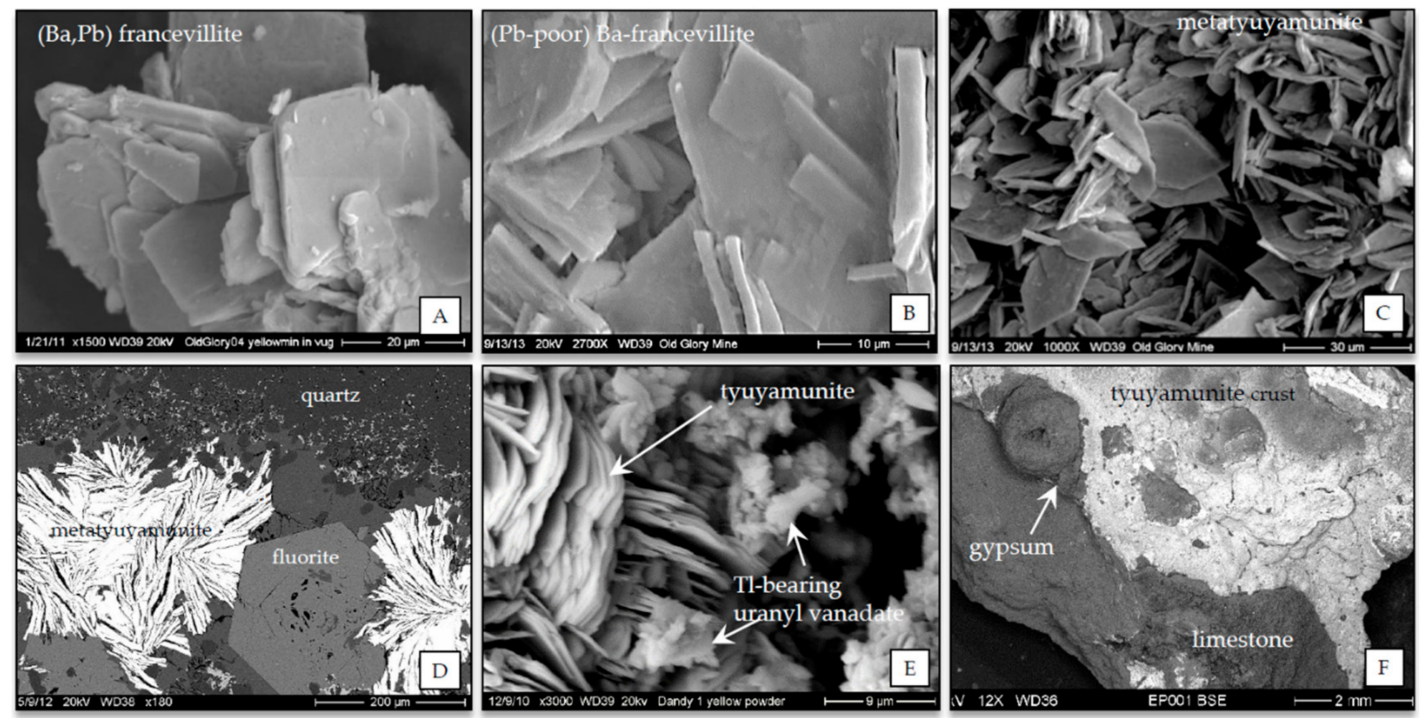

Figure 6. (A) (Ba,Pb) francevillite, Old Glory mine, Secondary Electron Imaging (SEI), 1500× magnification; (B) Ba francevillite, Old Glory mine, SEI, 2700× magnification; (C) Metatyuyamunite, Old Glory mine, SEI, 1000× magnification; (D) Metatyuyamunite with fluorite intergrown, with late calcite filling in porosity in a vug of a silicified breccia, Old Glory mine, Backscatter Electron Imaging (BSE), $180 \times$ magnification; (E) Tyuyamunite (left) and unidentified Tl-uranyl vanadate mineral, Dandy mine, SEI, $3000 \times$ magnification; (F) Cavern type deposit, tyuyamunite coating limestone with secondary gypsum, BSE, E. Pryor area. 


\subsubsection{Gangue Minerals Associated with Hydrothermal Dolomitization}

Tectonic hydrothermal brecciation with associated hydrothermal dolomite [46] and calcite has been documented in the Madison Group in the Bighorn Basin and nearby Wind River Basin in oil reservoir characterization studies [47-51]. The silicic THB, in this district are the first reported in the Bighorn Basin. Gangue minerals in both deposits associated with hydrothermal dolomitization include sulfides, oxides, hydroxides, hydrothermal "saddle" dolomite [52], and herkimer style, double terminated, quartz [53]. Pyrobitumen and bitumen, though not minerals, are also associated with hydrothermal dolomitization have been observed in this study. Fluorite and barite, only observed in the PMD, are also associated with hydrothermal dolomitization [46]. Other gangue minerals in the PMD that may have hydrothermal origins are halloysite and witherite, identified by XRD and EDS in this study [54,55].

\subsubsection{Bitumen, Sulfides, FeV Oxides, and Vugs}

Bitumen lines clasts, fills interparticle porosity, and is found as inclusions in samples (Figure 7A-E). Bitumen or hydrocarbons likely contributed to the gangue minerals present in the deposits because of similar trace element content. For example, Fe-sulfides (pyrite and marcasite) containing variable trace elements are found in the interparticle porosity or in fractures; these sulfides may have been derived from the metal-rich hydrocarbon brine solutions that permeated the deposits (Figure 7F-H).

Round pyrobitumen preserved in late-stage calcite (Figure 7E) may serve as an analogue for spherical shaped vugs found in cements of both districts. Vugs likely formed after hydrocarbon or volatiles were released or possibly dissolved in other episodes of fluid migration. Fluids introduced either hydrothermally or later from surface waters may have biodegraded the hydrocarbons by processes such as "water washing" when the breached structure was invaded with water. Spherical vugs with sulfides (Figure 7F), barite, clay coatings (Figure 7I,J), witherite, fluorite, Fe-V oxides (Figure 7I-N), or a combination of these minerals are found in samples from the PMD.

In mineralized silicified THB of the PMD, vugs lined with Fe-V oxides often have U-V minerals in the centers surrounded by bleached quartz rims (Figure 7M). Spherical, cubic, and hexagonal vugs are present in quartz cements of breccia in the PMD (Figure 7F,I,K,L). Cubic and hexagonal vugs may reflect minerals that were dissolved out, possibly magnetite, apatite, or barite.

In the LMD, tyuyamunite or metatyuyamunite crystals that radiate from round vugs in calcite cements are closely associated with Fe-oxides and or Fe-hydroxides (Figure 7O). Irregular shaped inclusions (possibly the remaining residuum after bacteria biodegradation of oil) were observed in calcite cement from LMD samples. Some of the inclusions had U-V minerals growing into them (Figure 7P); these were closely associated with Fe-oxides or Fe-hydroxides.

$\mathrm{Fe}-\mathrm{V}$ oxides, identified by EDS (Figures A6-A9) in samples are found in association with bitumen. EDS spectra of the Fe- $\mathrm{V}$ oxides show a high percentage of $\mathrm{Fe}$ which varies from around $32 \%$ to $70 \%$ weight percent. The spectra from the PMD samples also show moderately strong $\mathrm{V}, \mathrm{Si}, \mathrm{Al}, \mathrm{O}$, and no $S$ peaks, suggesting that the metals are iron oxides (magnetite, goethite, or hematite) coated with silicate minerals (probably clays).

$\mathrm{Zn}$ was detected in Fe-V oxide samples from the LMD (Figure A9). The Fe-V oxides may represent an isomorphous substitution of trace elements with Fe-oxides and hydroxides rather than a specific mineral phase. Using EDS, $\mathrm{Zn}, \mathrm{Cu}$, and $\mathrm{Ni}$ were detected in a mineral from the East Pryor mine area (Figure A10) likely reflecting metals derived from hydrocarbons based on chemical analyses of the bitumen from this study (Table A2). 

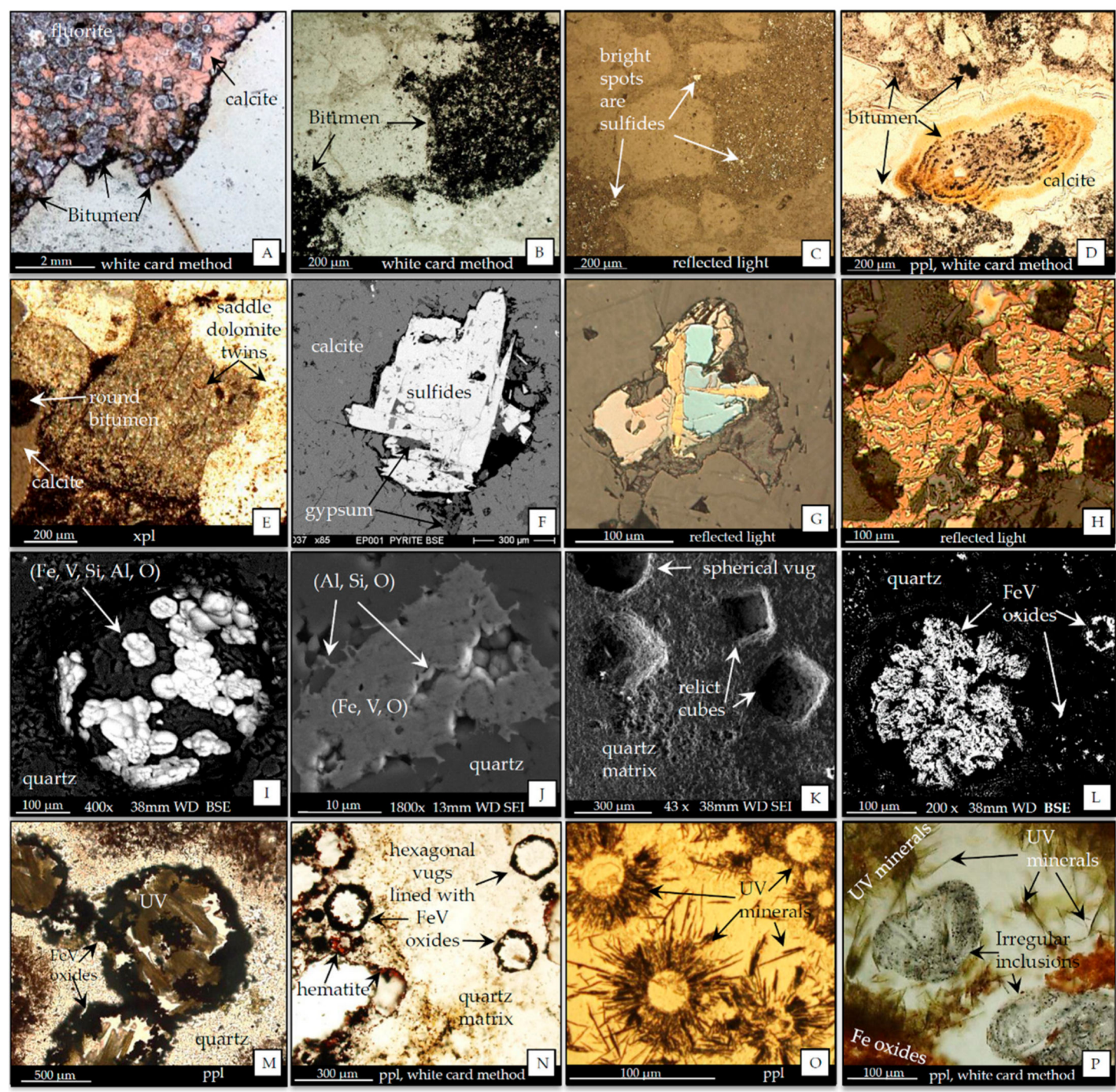

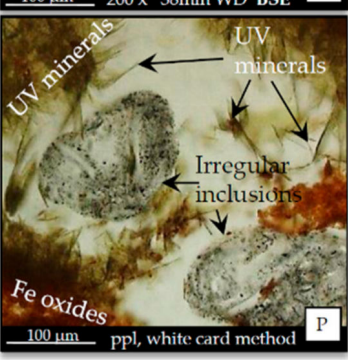

Figure 7. Images of bitumen and vugs: (A) bitumen lining clast of silicified limestone. Red stained calcite fills in porosity of oolites metasomatically replaced by fluorite, Dandy mine, PMD, ppl, white card method; (B) Bitumen filled in porosity of E. Pryor mine breccia, ppl, white card method; (C) Sulfides appear bright in reflected light view of B; (D) Calcite filling in fracture with bitumen inclusion "bleeding" out in concentric rings, Dandy mine, PMD, ppl, white card method; (E) Round bitumen is preserved in late-stage calcite of breccia and saddle dolomite twins show up in xpl, E. Pryor Mountain Group, PMD; (F) Sulfides and gypsum formed in round vug, E. Pryor mine, PMD, BSE; (G) Isotropic Fe-sulfides in reflected light; four different isotropic minerals are shown in this view, blue may be Ni-bearing pyrite and pinkish brown may be bornite $\mathrm{Cu}_{5} \mathrm{FeS}_{4}$, E. Pryor mine, ppl; (H) Two isotropic Fe-sulfides in reflected light exhibiting myrmekite texture, pyrite may be the yellow mineral, E. Pryor mine, ppl; (I) Fe-V oxides with clay mineral coating, BSE, 400× magnification; (J) Another portion of sample in 7I shows Fe-V oxides with clay mineral coating, SEI, 1800× magnification; (K) Spherical and cubic shaped vugs in quartz matrix, Old Glory mine, SEI, 43× magnification; (L) BSE of $\mathrm{K}$, microscopic Fe-V oxides visible in large vug, lining smaller vug and between microcrystalline quartz crystals, 200× magnification; (M) Tyuyamunite or metatyuyamunite crystals in Fe-V oxide lined, bleached circular vugs (N) Clear quartz matrix with hexagonal Fe-V oxide rimmed vugs and red hematite along edge, Old Glory mine, PMD, ppl, white card method; (O) Tyuyamunite or metatyuyamunite crystals radiating out from circular vugs in calcite fracture appear dark due to Ir coating on slide used for SEM work, LMD, ppl; (P) U-V minerals radiating from a fracture lined with Fe oxides, with irregular inclusions in a limestone breccia, LMD, ppl, white card method. Figure modified from Moore-Nall and Lageson [37]. 


\subsection{Cathodoluminescence}

$\mathrm{CL}$ revealed the episodic nature of calcite and fluorite. It highlighted U-V minerals and Fe-V oxides showing the close relationship of bitumen or hydrocarbons in the samples. The U-V minerals and Fe-V oxides fluoresce bright green due to $\mathrm{V}$; these minerals occur along fractures and interparticle pore space (Figure 8A). REE are common activators in fluorite [56,57]. A strong blue CL signal is generally attributed to the LREE fraction, with $\mathrm{Eu}^{2+}, \mathrm{Sm}^{3+}$, and $\mathrm{Dy}^{3+}$, serving as the main activators [56] while $\mathrm{Dy}^{3+}$ and $\mathrm{Tb}^{3+}$ are usually the activators in HREE environments, which impart a lilac color [56]. Hexaoctahedral fluorite from the Old Glory mine, PMD, alternates between blue and lilac colored zones (Figure 8B). Spheres of Fe-V oxides fluoresce green in the interparticle porosity of calcite and fluorite (Figure 8C,D). In transmitted, plane polarized light, the spheres are clearly visible in the same view of Figure $8 \mathrm{D}$ and in a standard petrographic image in quartz (Figure $8 \mathrm{E}$ ). Luminescence in carbonates is generally due to $\mathrm{Mn}^{2+}$ in the crystal and quenching by $\mathrm{Fe}^{2+}$ [58]. The calcite cements from this study fluoresce bright red orange alternating with dark zones, which is indicative of episodic Fe-rich hydrothermal sourced fluids [59]. REE-activated luminescence in sedimentary calcite is much lower than hydrothermal influenced carbonates, which often crystalize from REE-enriched solutions [58,59]. A corroded and fractured quartz veinlet from the Marie mine, PMD, reflects episodic fluid interactions. Calcite and bitumen filled in the pore spaces of the quartz veinlet. Inclusions in the bitumen along the edges of the quartz luminesce green, likely indicating V content (Figure 8G). In transmitted light view of the same image the quartz appears white (Figure $8 \mathrm{H}$ ). Sulfides are also common in the interparticle porosity of calcite and dolomite breccia in both mining districts and in fluorite in the PMD. The sulfides appear black in CL images (Figure 8I).

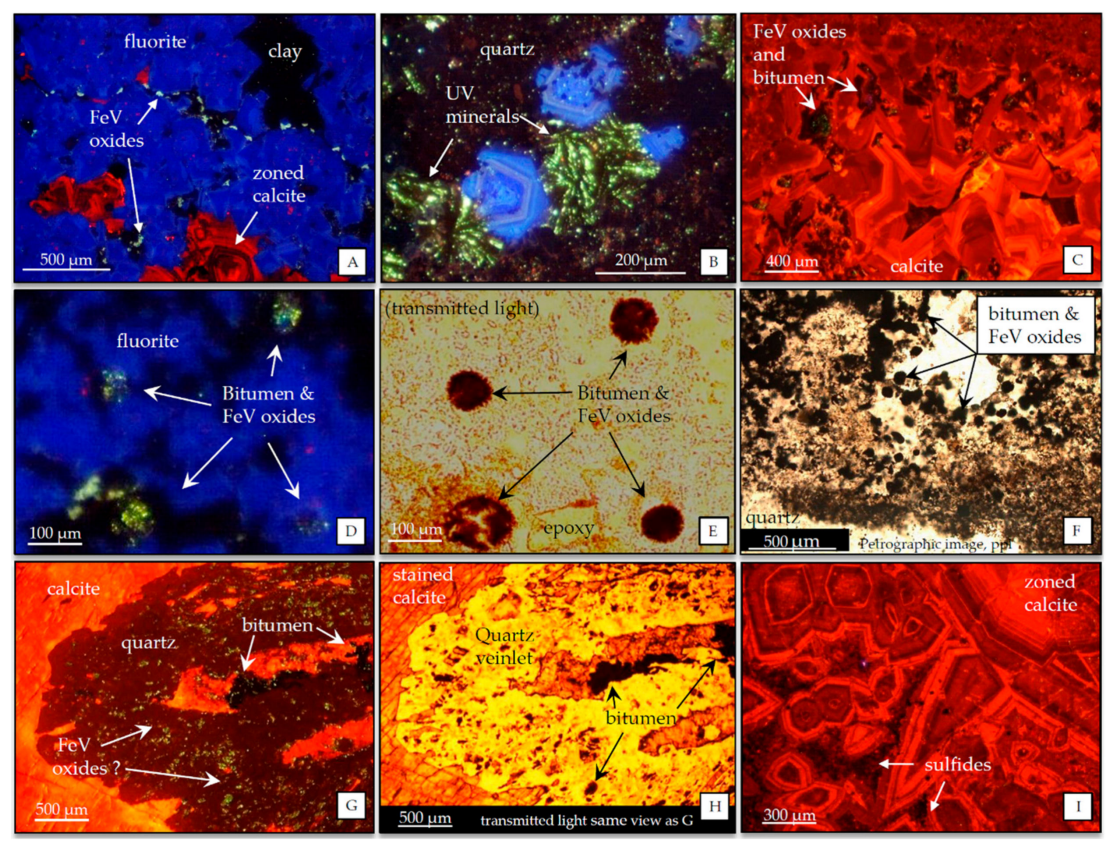

Figure 8. Cathodoluminescence (CL) images of samples from the study areas. (A) Blue fluorite with zoned calcite and Fe-rich clay coating calcite filling in the porosity. Green luminescing Fe-V oxides follow fracture and occupy pore space, Marie mine, PMD; (B) U-V minerals luminesce bright green with hexaoctahedral blue and lilac zoned fluorite in vug of a silicified breccia from the Old Glory mine; (C) Zoned calcite with bitumen and Fe-V oxides filling in the porosity, Lisbon mine, LMD; (D) Fluorite and with Fe-V oxides and bitumen spheres, Marie mine, PMD; (E) Transmitted light view of D; (F) Spheres of bitumen and Fe-V oxides in quartz, Old Glory mine, PMD; (G) Corroded quartz veinlet filled in by calcite and bitumen. Fe-V oxides luminesce green in the bitumen; $(\mathbf{H})$ Quartz appears white and bitumen black in the transmitted light view of G; (I) Zoned calcite with bitumen and sulfides filling in the porosity, Lisbon mine, LMD. Figure modified from Moore-Nall and Lageson [37]. 


\subsection{Fluid Inclusions}

Fluid inclusions in several samples from the PMD were analyzed by FLUID INC., Denver, CO, USA. A barite sample from the Swamp Frog mine contained yellow fluorescing primary inclusions; these were too small to study. Hydrocarbon ( $\mathrm{HC}$ ) inclusions are usually yellow and usually imply some sort of low API gravity [60] e.g., relatively heavy liquids—consistent with the HCs generated from Phosphoria source rocks for oil of the Bighorn Basin [61]. Jim Reynolds (pers. comm.) noted that the quartz and fluorite he examined from our study area appeared hydrothermal in origin, typical of what he observes in low-temperature $\left(<200^{\circ} \mathrm{C}\right)$ epithermal systems. The quartz and fluorite samples with $\mathrm{H}_{2} \mathrm{O}$ fluid inclusion assemblages had highly variable liquid to vapor ratios due to necking and were too small to obtain reliable homogenization temperatures. This is typical for low-temperature quartz in hydrothermal environments, because of the short-lived pulses of warm fluids, there is not enough geological time for maturation of the inclusions at low $\left(<200{ }^{\circ} \mathrm{C}\right)$ temperatures [61].

\subsection{REE and Geochemical Assay Data}

\subsubsection{Rare Earth Elements REE Plus Y}

Spidergram plots of REE plus Y normalized to NASC (North American Shale Composite) were produced from the data (Figure 9) using the values of Gromet et al. [62]. Plots were split up by similar REE plus Y patterns. The data from the bitumen, bentonite, and the average upper continental crust [63] are plotted together (Figure 9A). This plot shows the bitumen have a low concentration of REE compared to the average continental crust and the bentonite.

Most of the patterns plotted from the data of mineralized and gangue minerals resemble portions of the bitumen patterns. The bentonite sample data plotted with the bitumen and average crustal abundance data has the largest negative Eu anomaly of the data. The Permian Goose Egg hosted bitumen differs from the Mississippian Madison (Mm) Group hosted bitumen. It has lower REE concentration, no Eu, no $\mathrm{Lu}$, and a flatter, irregular HREE and $\mathrm{Y}$ pattern. Many of the patterns from the samples in this study reflect portions of the Mm hosted bitumen patterns (Figure 9B-E). These patterns were split up based on the steepness of the LREE patterns and similar patterns to each other.

Some samples from both districts have patterns similar to both the Permian Goose Egg hosted and Mm hosted bitumen (Figure 9F,G). Other samples have patterns more similar to the Permian Goose Egg hosted bitumen than to the Mm hosted bitumen (Figure 9H,I). The Tensleep Sandstone (TS53) hosted quartz (Figure 9H) differs the most of the quartz samples. It lacks Eu and has a LREE composition very similar to the Permian Goose Egg carbonate hosted bitumen, but differs from the bitumen and other quartz samples (Figure 9F,H,I) with a positive sloping HREE pattern.

All the samples have greater REE plus $\mathrm{Y}$ concentrations than the bitumen except for two speleothem calcite samples from Big Pryor Mountain (Figure 9H). The speleothem calcite have the least concentration of REE of all the samples reflecting the typical low REE concentrations in natural waters [63]. The fluorites are the most enriched in REE plus $Y$ of the gangue minerals and are more enriched than many of the U-V mineralized samples (Figure 9C,D). The Sandra Mine U-V samples are the most enriched in REE plus Y (Figure 9C).

The REE and Y pattern for barite from the Swamp Frog mine differs most from other data patterns in this study though is similar to the HREE portion of the Goose Egg bitumen pattern between Dy and Tm (Figure 9I). The pattern is similar to the quartz with pyrite from the Lisbon mine sample pattern (Figure 9I). The Old Glory mine sample (solid black line and yellow filled symbols) is similar to the barite sample from Ho-Yb in the HREE portion of the pattern. Both the Old Glory sample and the barite sample are somewhat enriched in Sm relative to the other REE in each sample. The Old Glory sample has Eu where the rest of the samples in this group do not.

Three U-V breccia data patterns from the Dandy, Old Glory and Marie mines do not match the bitumen patterns. These patterns have convex light and middle REE with flat to irregular HREE patterns (Figure 9J). The patterns in this set as well as those from Figure 9I and the Tensleep Sandstone 
hosted quartz (Figure $9 \mathrm{H}$ ) may reflect a contribution from a different source, possibly the inferred intrusion to the west of the PMD (Figure 1) $[5,6,16]$, or some other fractionation process during mineral formation.

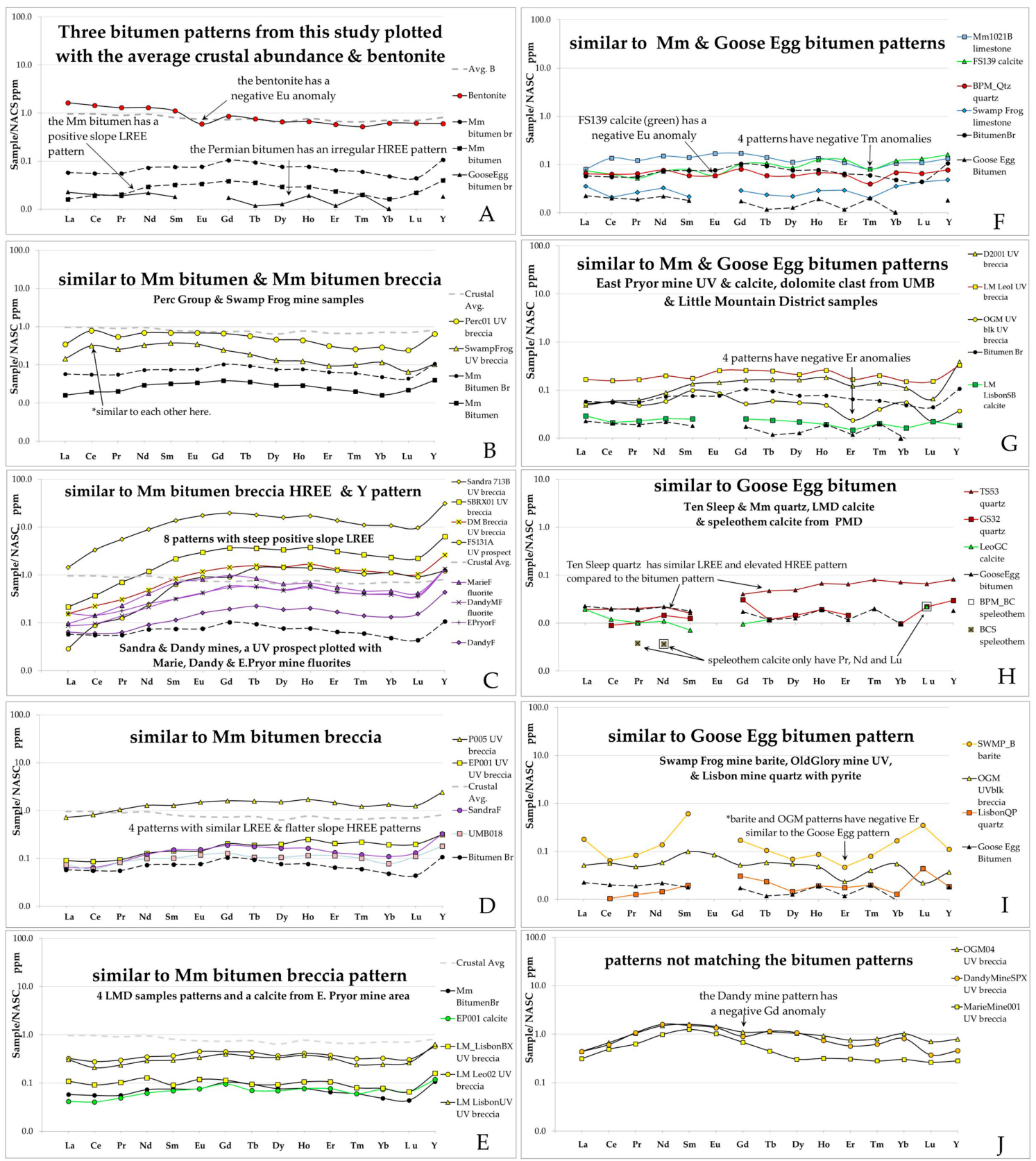

Figure 9. Spidergram plots of REE plus Y data from (North American Shale Composite) NASC-normalized samples. Each graph (A-J) is plotted using a log base 10 scale (range is 0.01 ppm-100 ppm). Plots are split up by similar REE and Y patterns. The bitumen data are plotted in Figure 9A with the bentonite and the average crustal abundance. Many of the mineralized and gangue minerals resemble portions of the bitumen patterns. Those patterns that are similar to the bitumen are plotted with bitumen (B-I). Mississippian Madison Group is abbreviated Mm in the plots.

\subsubsection{REE Analyses of Permian Phosphoria Formation Data}

The U.S. Geological Survey (USGS) studied the Permian Phosphoria Formation and related rock units in the Western U.S. Phosphate Field in southeast Idaho, southwest Wyoming, and southwest 
Montana (Figure 10) throughout much of the twentieth century [20-22,64-77]. The deposit has been a major phosphate resource for agricultural fertilizer [70]. Early studies were to evaluate the economic resources of this deposit which is enriched in many metals, define its origin, and aid in exploration for similar deposits [70]. REE and trace element data were used in many of the studies to define the origin [69-71,73,74]. Later studies focused on reaction pathways, transport, and fate of potentially toxic trace elements (Se, $\mathrm{Cd}, \mathrm{Tl}, \mathrm{Hg}$, As, etc.) associated with the occurrence, development, and societal use of phosphate [71,72]. A recent study has shown that phosphorite deposits including the Phosphoria Formation are enriched in REE that would be easily recoverable as a byproduct of phosphate production [75]. The REE occur in the francolite $\left(\mathrm{Ca}_{5}\left(\mathrm{PO}_{4}\right)_{3} \mathrm{~F}\right)$ portion of the Phosphoria phosphorite rock, a carbonate-rich fluorapatite, which is beneficiated or physically concentrated and dissolved in sulfuric acid to produce fertilizer [76]. In the study, dilute $\mathrm{H}_{2} \mathrm{SO}_{4}$ and $\mathrm{HCl}$, extracted nearly $100 \%$ of the total REE content of the phosphorite samples in leaching experiments [75].

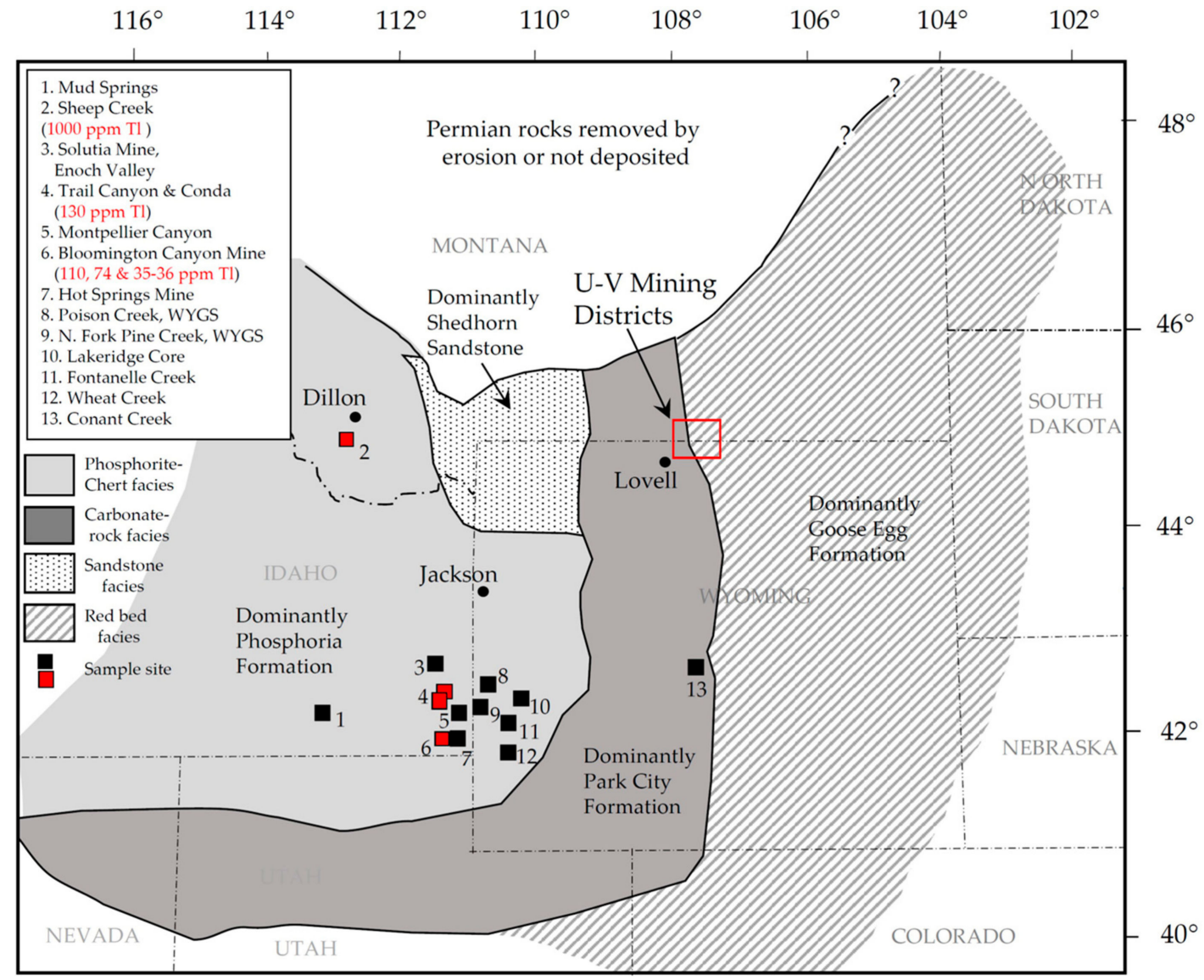

Figure 10. Index map showing location of dominant facies of rocks of Permian age. The numbered sites (filled squares) give the approximate location of the sample sites for which samples have been analyzed for major-element oxides and trace elements in previous studies [66,67,69,70,74,75,77]. Red filled squares are sites that had samples with greater than $100 \mathrm{ppm}$ concentration of Tl. The map is adapted from Sheldon, 1963 [65] and locations from the different studies.

For this study, data from several studies carried out by the USGS and the Wyoming State Geological Survey of the Phosphoria Formation in ID, WY and MT [64-67,73-77] was examined. Figure 10 shows the locations of samples sites and the approximate location of this study; map shows approximate location of the Permian age rock. Also noted are the locations of samples that had greater than $100 \mathrm{ppm} \mathrm{Tl}$. Not all of the studies included Tl as one of the analytes. 
Data from analyses of rock samples studied by the USGS from MT, ID, and WY was normalized to NASC (North American Shale Composite) using the values of Gromet et al. [62]. Two main patterns are present in the USGS data: (1) a strong negative Ce anomaly with HREE patterns showing slightly elevated Gd and Y (Figure 11A) and (2) patterns with little or no Ce anomaly and flatter HREE and Y patterns compared to the average crustal abundance pattern (Figure 11B). Most of the data reviewed (approximately 90\%) in the USGS studies had the strong negative Ce anomaly. Six sample analyses from this study plotted with data from the USGS studies show similar REE and Y concentrations and patterns (Figure 11C). Samples from the Sandra mine are comparable in concentration of HREE and $Y$ to the most enriched of the USGS samples (Figure 11C).

Fractionation of $\mathrm{Ce}$ in the marine environment has been attributed to the oxidation of $\mathrm{Ce}^{3+}$ to $\mathrm{Ce}^{4+}$ and subsequent removal by suspended Fe and Mn particles in the water column or solid phases residing on the sea floor [75,78-80]. This results in REE patterns with the distinctive negative Ce anomaly characteristic of seawater $[75,78-80]$. The negative Ce anomaly is often associated with the precipitation of Mn nodules [80]. For an example, Mn nodules occur in a fine grained argillaceous sandstone bed of the Franson Tongue Member of the Park City Formation, Dillon, MT [66]. The depletion of Ce and the REE content of the U.S. Geological Survey samples, including the Permian nodules, were attributed mainly to the apatite fraction present in the samples as the mineral francolite [69-71,75]. The bitumen samples in our study lack the Ce anomaly, although they display similar HREE and Y patterns to the Phosphoria rock sample REE patterns. The bitumen REE patterns likely represent the fractionation of the REE as a group due to the maturation and migration of the hydrocarbons and brines from the Phosphoria Formation as the depth of the overlying sediments increased in the Bighorn Basin. REE are mobilized in hot reducing conditions typical of deep basin brines [63].

\subsubsection{Concentration of Metals in the Phosphoria Formation and in the U-V Deposits}

Geochemical analyses from the vanadiferous portions of the Phosphoria Formation of WY, ID and MT have anomalous high values of many metals. Some maximum values include: $857 \mathrm{ppm}$ As, $22 \mathrm{ppm}$ Ag, 3000 ppm Ba, 3000 ppm Cd, 150 ppm Co, 30,800 ppm Cr, 1.6 ppm Hg, 16,000 ppm Mn, 280 ppm Mo, >1000 ppm Ni, 668 ppm Pb, 1200 ppm Se, 130 ppm Tl, 328 ppm U, 35,840 ppm V, 1600 ppm Y, 15,000 ppm Zn and 2158 REE ppm [20,21,64-75]. Analyses of the Mn nodule used in Figure 11 above from a U.S. Geological Survey study near Dillon, MT had low total REE but high compositions of other metals: 400 ppm As, 1200 ppm Cd, 2200 ppm Co, 70 ppm Mo, 13,000 ppm Ni, 1 ppm Te, 1000 ppm Tl, 700 ppm V, and 25,000 ppm Zn [66].

U-V samples from this study contain anomalously high concentrations of many of the same metals supporting derivation from this source (Table 2). The bitumen do not have high concentrations but do have many of the elements of concern in this study. All these elements would not stoichiometrically fit into the structure of the minerals in this study. As hydrocarbons and brines migrated into the structures hosting the deposits, it is likely many of these metals were incorporated as inclusions in minerals or breccia cement. 


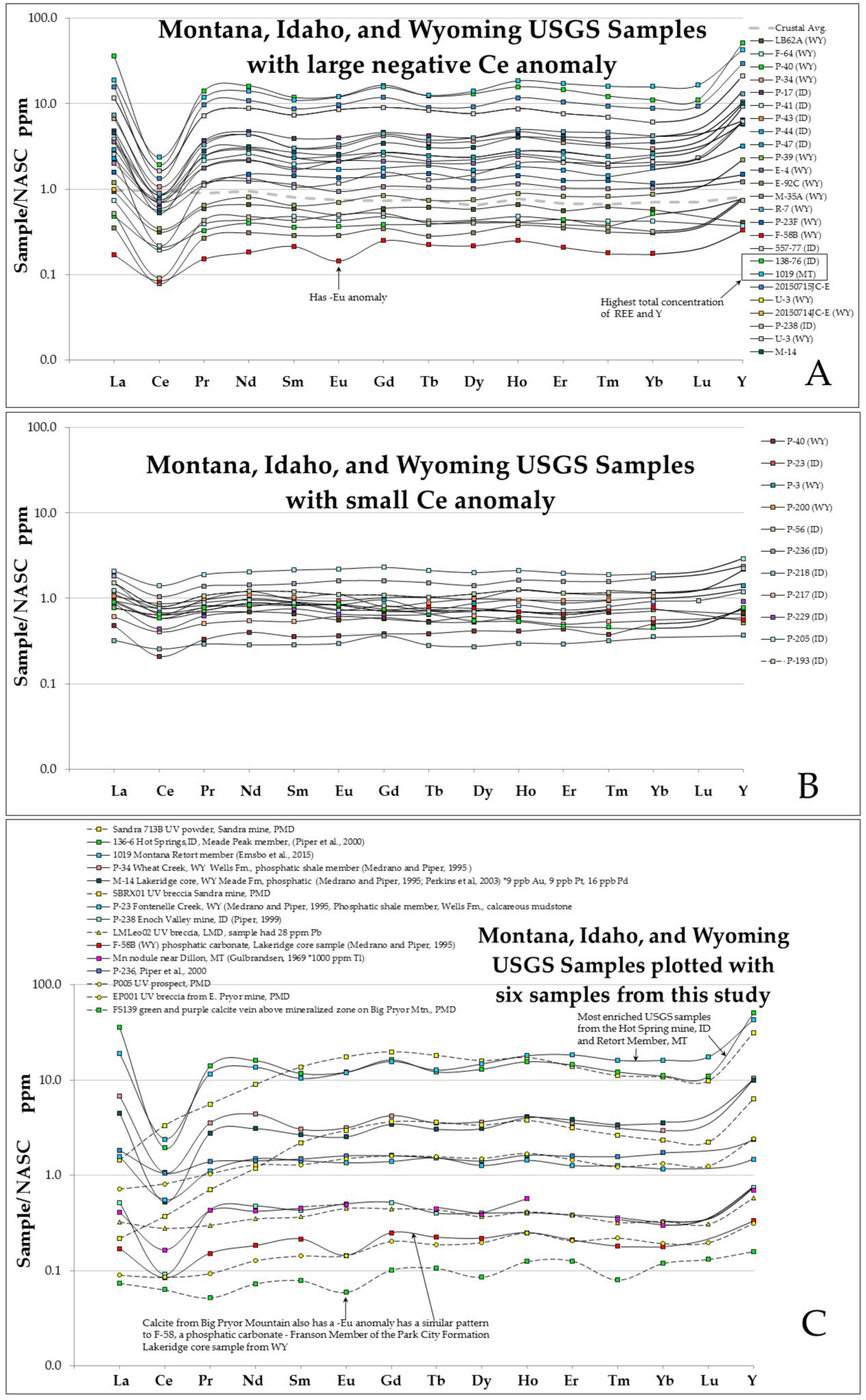

Figure 11. NASC-normalized REE and Y Permian Phosphoria Formation rock sample data (A) with strong negative Ce anomaly, slightly elevated Y; (B) with smaller negative Ce anomaly and flatter HREE and Y pattern; (C) Six samples from this study plotted with United States Geological Survey (USGS) samples. The most enriched PMD sample has similar, slightly higher concentration of REE and Y from Sm-Ho to the most enriched USGS sample. The only PMD sample with a negative Eu anomaly is similar to a phosphatic carbonate from the USGS Lakeridge core, WY that also has a negative Eu anomaly. 
Table 2. U-V breccia samples contain elevated concentrations of many of the same elements detected in the Permian Phosphoria Formation samples collected by the USGS. Elements that are elevated greater than the average crustal abundance are shown in red and blue highlighted text in the table. Highest values are outlined in black boxes. The samples listed are the U-V breccias except the bottom three samples which are the bitumen samples. The average crustal abundances for these elements are listed in the second row. Values are in ppm.

\begin{tabular}{|c|c|c|c|c|c|c|c|c|c|c|c|c|}
\hline \multicolumn{2}{|c|}{ District Sample } & As & $\mathbf{B a}$ & $\mathrm{Hg}$ & Mo & $\mathrm{Ni}$ & $\mathrm{Pb}$ & $\mathrm{Tl}$ & $\mathbf{U}$ & V & $\mathbf{W}$ & $\mathrm{Zn}$ \\
\hline \multicolumn{2}{|c|}{ Avg. crustal abund. } & $0.8-1.5$ & $150-500$ & 0.067 & $0.8-1.5$ & $44-156$ & $5-17$ & $0.2-0.8$ & $0.5-3$ & $107-271$ & $0.7-2$ & $71-83$ \\
\hline PMD & FS131A & 262 & 1230 & 2.84 & 53 & $<1$ & $<2$ & 180 & 86,800 & 18,900 & 94 & 16 \\
\hline PMD & Sandra713B & 99 & 6550 & 1.485 & 29 & 167 & 44 & 20 & 21,400 & 8730 & 24 & 804 \\
\hline PMD & SBRX Sandra & 49 & 5460 & 0.333 & 11 & 38 & 7 & 10 & 2600 & 1950 & 71 & 136 \\
\hline PMD & Perc Group & 329 & 5170 & 1.21 & 52 & 19 & 51 & 170 & 20,700 & 6700 & 30 & 95 \\
\hline PMD & OGM04 & 1295 & 2310 & 0.354 & 152 & 2 & 13 & 100 & 10,600 & 4410 & 105 & 26 \\
\hline PMD & P005 & 1080 & 1305 & 1.255 & 386 & 80 & 18 & 340 & 9000 & 6010 & 19 & 165 \\
\hline PMD & Swamp Frog & 556 & 1320 & 0.396 & 791 & 11 & $<2$ & 340 & 6100 & 4160 & 81 & 44 \\
\hline PMD & DandyMSP & 94 & 2470 & na & 20 & $<1$ & 35 & 490 & 8600 & 2220 & 382 & 9 \\
\hline PMD & MarieMine & 87 & 533 & 1.715 & 319 & 15 & $<2$ & 30 & 2100 & 6740 & 40 & 57 \\
\hline PMD & D2001 & 87 & 79.5 & 6.32 & 9 & 2 & 35 & 50 & 17,700 & 6310 & 16 & 849 \\
\hline PMD & DandyMSPF & 30 & 39.6 & 3.4 & 4 & 21 & 8 & 10 & 3000 & 3320 & 12 & 76 \\
\hline PMD & DandyMBr & 130 & 61.3 & 12.8 & 28 & 102 & 55 & 20 & 28,100 & 10,500 & 26 & 1110 \\
\hline LMD & Lisbon & 89 & 42.6 & 0.197 & 25 & 421 & 146 & 30 & 31,100 & 8520 & 11 & 1300 \\
\hline LMD & LeoIncline02 & 726 & 255 & 0.179 & 137 & 517 & 57 & 230 & 16,000 & 10,300 & 11 & 2230 \\
\hline PMD & OGM UV blk & 46 & 1530 & na & 21 & $<1$ & 2 & 50 & 4900 & 1240 & 107 & 7 \\
\hline PMD & EP001 & 50 & 27.6 & na & 2 & 63 & 11 & 10 & 907 & 25 & 6 & 143 \\
\hline LMD & LeoIncline & 116 & 183 & na & 98 & 191 & 28 & 20 & $>1000$ & 4330 & 13 & 970 \\
\hline LMD & LisbonBX & 212 & 140 & na & 93 & 122 & 4 & 10 & 1300 & 1850 & 12 & 569 \\
\hline LSM & Mm hosted bit. & 0.2 & 10 & 0.01 & 1.63 & 14.1 & 0.9 & 0.02 & 6.8 & 73 & 8.6 & 5 \\
\hline LSM & Mm breccia bit & $<0.1$ & 20 & $<0.01$ & 0.12 & 1.5 & 0.5 & $<0.02$ & 4.04 & 7 & 2.4 & 2 \\
\hline LSM & GooseEgg bit. & 1 & 630 & 0.01 & 0.46 & 3.2 & 1.5 & 0.03 & 11.6 & 8 & 21 & 9 \\
\hline
\end{tabular}

Note: PMD—Pryor Mountain District; LMD—Little Mountain District; LSM—Little Sheep Mountain; Mm—Mississippian Madison Limestone; na—not analyzed. 


\section{Discussion}

\subsection{Phosphoria Oil Migration and Oilfields in the Bighorn Basin}

Originally, Phosphoria Formation-sourced hydrocarbons accumulated in the Bighorn Basin in stratigraphic traps created primarily by up dip facies change, pinch out and truncation of reservoir carbonates, and by uneven Phosphoria Goose Egg truncation of the underlying Pennsylvanian Tensleep Sandstone $[23,24]$. The timing of the first migration of Phosphoria sourced oil ranges from Jurassic to late cretaceous in time [81]. The Cottonwood Creek oil field in the southeastern Bighorn Basin produces from a stratigraphic trap (Figure 12). The oil produced in the field is from a Phosphoria Formation reservoir with a seal formed by impermeable Permian Goose Egg shales and anhydrites [82], similar to the original pre-Laramide stratigraphic traps. Seven of the top ten producing oilfields in WY are in the Bighorn Basin. These are highlighted in red in Figure 12. The primary oil production in the northern Bighorn Basin was from Mississippian age reservoir rock in two of the top seven fields show in Figure 12. These fields, Elk Basin and Garland, may serve as analogues for the structures hosting the U-V deposits in the two districts. Both Elk Basin and Garland produce heavy oil and significant hydrogen sulfide is associated with the Elk Basin oilfield [40].
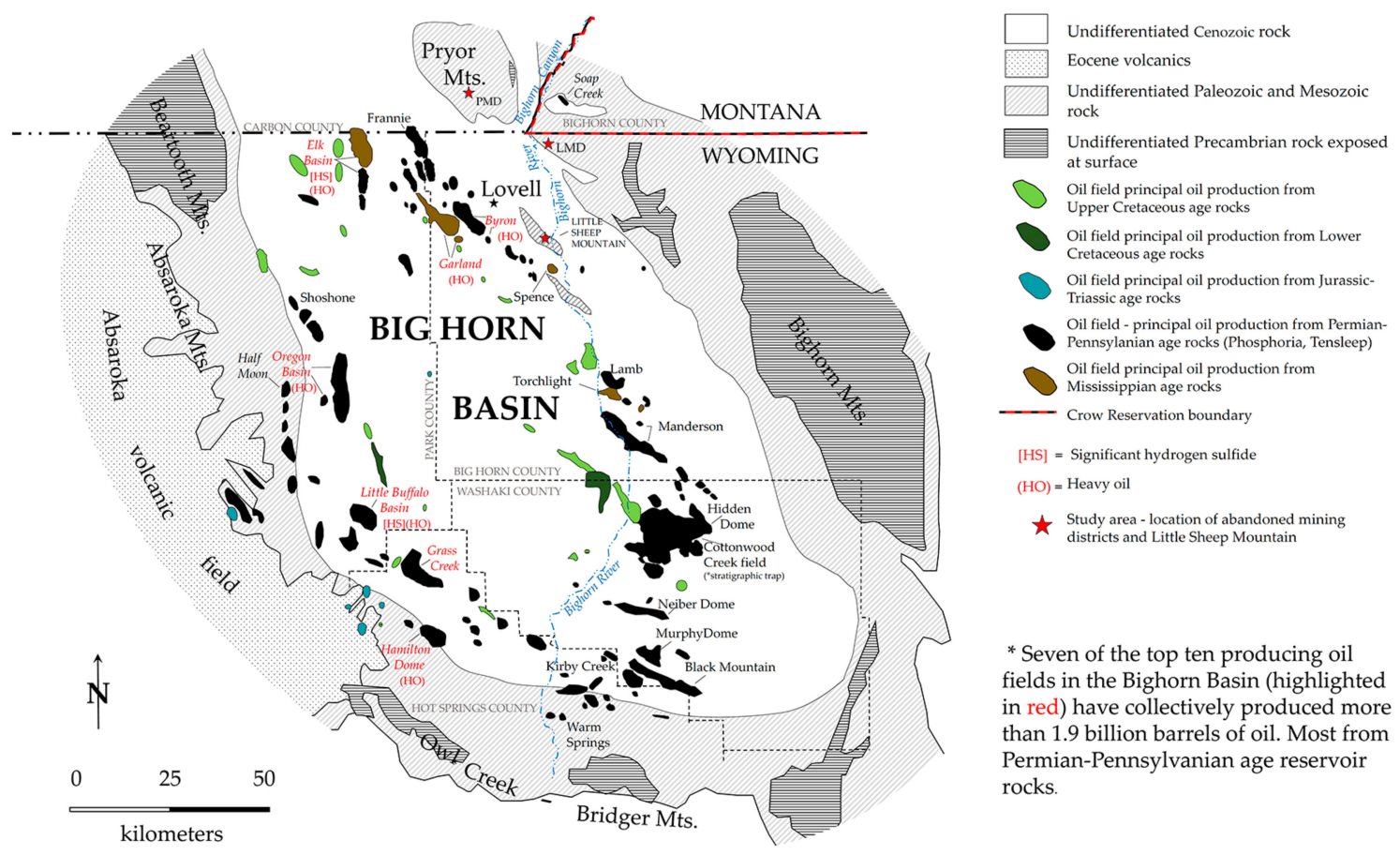

Figure 12. Map showing approximate location of some of the main oilfields in the Bighorn Basin. The study areas are shown by the red stars. Oil field locations and reservoir rock designation are modified from the Wyoming State Geological Survey's Wyoming Oil and Gas Field map, 2016 [82]. Figure modified from Wyoming State Geological Survey [82].

\subsection{Origin of Bitumen and Heavy Oil}

Most heavy oil and natural bitumen is thought to be the residue of formerly light oil that has lost its light-molecular-weight components through degradation by bacteria, water-washing, and evaporation $[83,84]$. Meteoric water is the commonly accepted vehicle for bringing dissolved oxygen and microbes into contact with oil reservoirs, either along faults or fractures or by aquifers in hydrodynamic connection with the surface [84]. Generally, this is under aerobic conditions at depths of about $1524 \mathrm{~m}$ or less and temperatures below $80^{\circ} \mathrm{C}$ [83]. Hydrocarbons are oxidized completely to carbon dioxide and water without intermediate products by many bacteria [84]. This results in the 
remaining residue of solid bitumen and asphalts which are enriched in heavy N, S, O compounds [84]. Some average chemical variations in conventional oil and bitumen that have been observed in studies from basins around the world show an increase in the metal concentration in bitumen compared to conventional oil. Based on studies from approximately 8500 deposits there is an increase in the metal concentration in bitumen compared to conventional oil [83]. For example conventional oils have average concentrations of approximately 1 ppm Pb, 16 ppm V, 6 ppm Fe, 1 ppm Al, 8 ppm Ni, and $0.5 \mathrm{ppm} \mathrm{Cu}$. and bitumen has concentrations of approximately $5 \mathrm{ppm} \mathrm{Pb}, 335 \mathrm{ppm} \mathrm{V}, 4290 \mathrm{ppm} \mathrm{Fe}$, 21,000 ppm Al, 89 ppm Ni and 44 ppm Cu [83]. Hg however, is less concentrated in bitumen 0.019 ppm compared to an average of about $19 \mathrm{ppm}$ in conventional oil [83]. This may suggest that $\mathrm{Hg}$ is being mobilized in the biodegradation process. The combination of aerobic and anaerobic heterotrophic bacteria metabolic processes and subsequent water washing likely results in mobilization of some metals during biodegradation and enrichment or a sink for others.

\subsection{Style of Breaching of Oil Traps in the Study Areas}

We suggest that the structures hosting the U-V deposits likely had Phosphoria sourced oil in structural traps until they were breached. Breaching of the structures in each district was not synchronous or of the same style. The folds hosting the deposits are of different scales, maturity, and elevation. We suggest that breaching and subsequent $U$ mineralization in the PMD was earlier than in the LMD based on elevation and structural maturity of the folds.

The PMD is approximately $1000 \mathrm{~m}$ higher elevation than the LMD. The Gypsum Creek anticline, the main fold hosting the U-V deposits in the PMD, was breached as the Crooked Creek fault propagated up through its core extending beyond the Madison Group.

The folds hosting the deposits in the Little Mountain area are smaller in scale and less structurally mature than those in the PMD in the sense that the master faults did not fully propagate through the structures. The Porcupine Creek anticline, one of the main structures hosting the U-V deposits in the LMD, was breached by the superposition of the ancestral Bighorn River across its axis, forming part of the Bighorn Canyon.

\subsection{Paragenesis of $U$ Minerals in the Two Districts}

The paragenesis of $U$ minerals in the two districts is slightly different due to structure, elevation and position in the Bighorn Basin. The initial evolution of the U-V mineralization in both districts is related to the migration of the oil and brines from the Bighorn Basin into structural traps as folding proceeded in the two areas. Simplified conditions for mobilizing metals in a basin environment are increased temperatures, lower $\mathrm{pHs}$, and increased salinities. $\mathrm{U}$ would be stable in a reduced $\mathrm{U}^{4+}$ state in the basin environment and would likely form $\mathrm{F}$ and $\mathrm{Cl}$ complexes, which stabilize $\mathrm{U}^{4+}$ in solution [85]. Abundant $\mathrm{F}$ would have been available from the apatite of the Permian Phosphoria Formation. These complexes could have migrated with oil and been in solution in the traps until the structure was breached. Once oxidized meteoric water was available $\mathrm{U}^{+4}$ would oxidize to $\mathrm{U}^{+6}$ to stabilize the uranyl ion, $\mathrm{UO}_{2}{ }^{2+}$, and its complexes [86,87]. The uranyl ions would bind with available metals and precipitate out as various uranyl minerals. All the identified $U$ minerals in the districts are uranyl minerals with the Ca-uranyl vanadates being the most common.

The uranyl silicates, phosphates, and vanadates are relatively insoluble and require $\mathrm{Si}, \mathrm{P}$, and $\mathrm{V}^{5+}$, respectively to precipitate [86]. These elements can be derived from a variety of sources. In many $U$ deposits, metal-uranyl vanadates are derived from the oxidation of $\mathrm{U}^{+4}$ minerals such as uraninite [85-87]. In this study, however, no $\mathrm{U}^{+4}$ minerals have been observed. This suggests that the metal-uranyl vanadates are primary (did not oxidize from a reduced $U$ mineral such as uraninite). We suggest that these metals were derived from the biodegradation of the oil once the basin fluids mixed with the meteoric groundwater after the structures were breached. 


\subsubsection{Mineral Paragenesis PMD}

The two mining districts are hosted in the same paleokarst horizon with nearly identical ore minerals but differ in gangue minerals; notably fluorite, barite and abundant quartz present only in the PMD. Two episodes of siliceous fluid migration are apparent in the PMD. The first significant siliceous fluid migration was the emplacement of silica cemented THB. We suggest these were emplaced as a result of earthquake induced seismic pumping during the Laramide Orogeny that hydrofractured the host rock $[47,88,89]$. The resulting fractures and brecciation were healed by the rapid precipitation of quartz in the earlier episodes during subsequent and sudden decrease in the partial pressure of $\mathrm{CO}_{2}$ [88]. As the master faults propagated along the same faults and the process would be repeated forming new or following previous fractures [88]. The earlier siliceous THB had abundant Fe-oxides with trace amounts of $\mathrm{V}, \mathrm{Tl}, \mathrm{Pb}$, and Ti present in the matrix (Figure 13A). Early barite was associated with the first pulses of siliceous THB evident by the inclusions of barite in the siliceous cement of the THB (Figure 13B). Later barite precipitated along fractures and in vugs (Figure 13C).

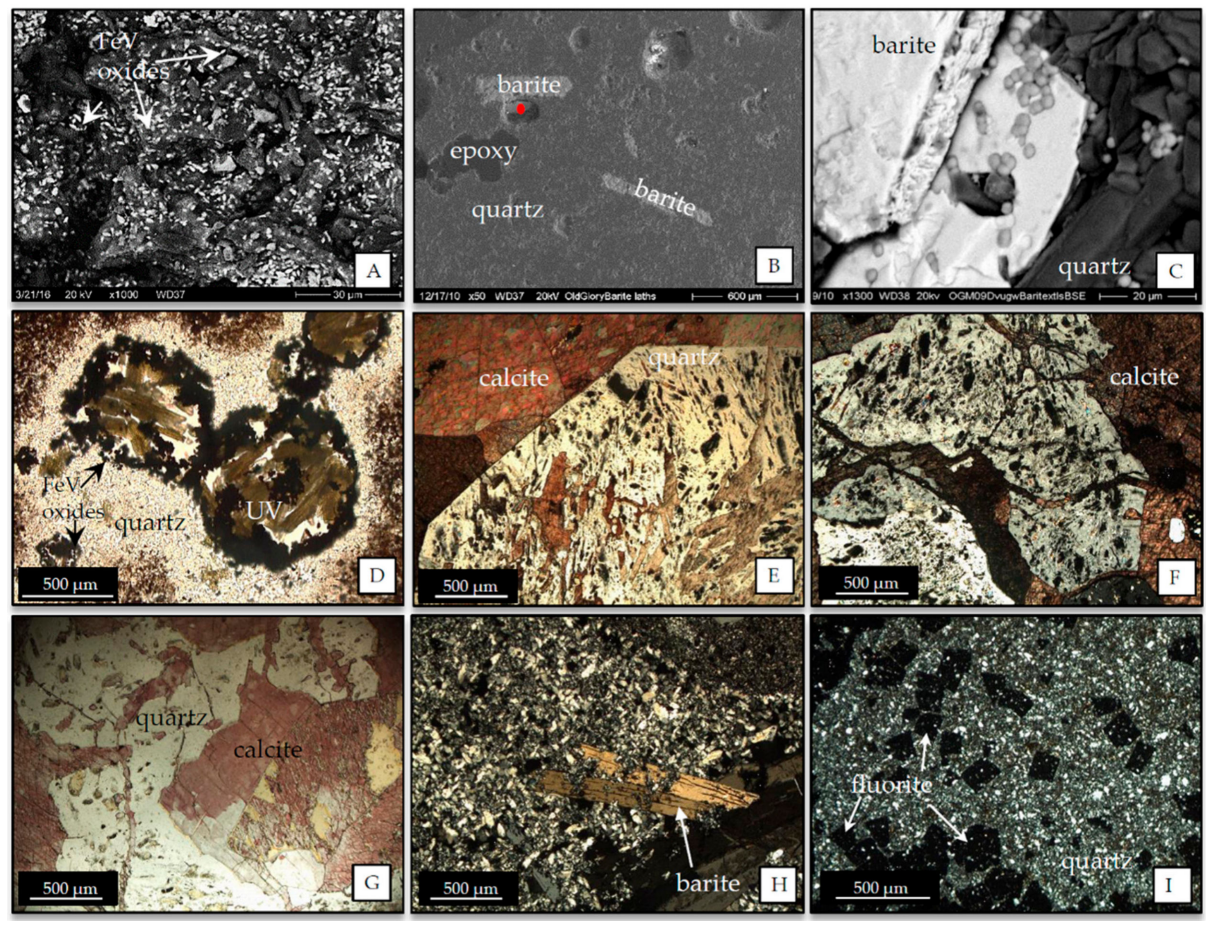

Figure 13. Barite and quartz in the PMD. (A) Fe-V oxides with trace amounts of $\mathrm{Tl}, \mathrm{Pb}$ and $\mathrm{Ti}$ in quartz matrix of a THB from the Old Glory mine, PMD, BSE, 1000 $\times$ magnification; (B) Barite laths in quartz matrix with barite in vug marked by red dot, SEI, 50× magnification; (C) Barite from vug in Figure 13B formed around spherical minerals with $\mathrm{Fe}, \mathrm{Si}, \mathrm{Al}$, Ba and S, BEI, $1200 \times$ magnification; (D) Tyuyamunite or metatyuyamunite crystals in Fe-V oxide lined, bleached circular vugs; (E) Sharp euhedral crystal boundary of corroded quartz grain and red stained calcite fill in irregular vugs in quartz, Marie mine, PMD, xpl, white card method; (F) Quartz veinlet, micro fractured with mosaic pattern, healed by calcite, Marie mine, PMD, xpl; (G) Quartz veinlet, micro fractured with mosaic pattern, healed by red stained calcite, Marie mine, PMD, ppl, white card method (H) Grey and white euhedral microcrystalline quartz filling in void space around earlier barite, Swamp Frog mine, PMD, xpl; (I) Cryptocrystalline quartz filling in around isotropic fluorite cubes, Dandy mine, PMD, xpl.

Quartz, barite and fluorite also precipitated after the emplacement of the siliceous THB in fractures and vugs, often accompanied by U-V minerals. These minerals likely represent the breaching of the structure by the full propagation of the fault through the Madison Group. The oxidized meteoric ground waters likely mixed with the oils and brines that were present in the structure, migrated down 
into fractures, and precipitated the ore and gangue minerals in the vugs and fractures of the THB and along other fractures in collapse paleokarst in the area (Figure 13E-G). Oxidized fluids migrating down into fractures occupied by the THB could explain the hematite- and limonite-staining that resulted from the oxidation of the Fe-V oxides present in the THB. The meteoric sources may have been lakes, ponds and or an ancestral river that occupied the area during the time the structure was breached or later as the Bighorn Basin was exhumed.

The quartz cement in the THB may be related to the inferred intrusion. It may have formed in a similar timeframe to the Sliderock volcano and the Lodgepole intrusive, part of an extensive NW-trending volcanic field that lies astride the folds and faults of the Nye-Bowler lineament $[90,91]$ (Figure 3, laccoliths). The alignment of these volcanic intrusives along the Nye-Bowler lineament strongly suggests the fault zone controlled the emplacement of the volcanic centers of the field [90]. Thus, it would not be unreasonable to have another intrusion along the same NW-trending lineament that formed because of low-angle subduction of the Farallon plate. The igneous products of the Sliderock Mountain stratovolcano were interpreted to be the products of arc-related magmatism based on geochemistry [90]. The inferred intrusion may account for the $\mathrm{Si}, \mathrm{Ba}, \mathrm{Au}$, and other metals present in the minerals of the PMD and not present in the LMD. Evidence supporting the inferred intrusion near the PMD include:

$>$ High aeromagnetic anomaly identified in 1982 southwest of the Big Pryor Mountain block by the Department of Energy [16] and supplemental geophysical work by the USGS in 1985 [5,6].

$>$ Gold detected in samples from this study by commercial assays (Appendix A, Table A1) and using the SEM. An abandoned gold lode deposit west of the PMD may have been associated with an intrusion (Figure 1, green symbol).

$>$ High concentrations of $\mathrm{Tl}$ (up to $490 \mathrm{ppm}$ ) in the PMD. Tl is not common but is commonly associated with Carlin-type gold deposits that have a close proximity to Eocene volcanic centers or plutons [92-96]. Thus, the Tl and Au detected in the PMD could support an intrusion.

> Proximity of the Late Cretaceous 78-75 Ma. diorite to granodiorite Sliderock stratovolcano and the Lodgepole intrusive $[90,91]$ that is suggested to have been controlled by the E-W trending Nye Bowler lineament.

$>$ Abundant fluorite and barite in the PMD. High concentrations of Ba in the PMD samples with the highest values excluding the barite samples ranging from (5460-6550 ppm).

$>$ High silica content of the tectonic breccias, highly fractured zones with white "bull" quartz and a few outcrops or lag deposits of the same, and high silica content (95\%) in reported ore during the years that the mines were operating [5].

\subsubsection{Mineral Paragenesis LMD}

The LMD deposits are hosted in smaller folds than the Gypsum Creek and East Pryor Mountain anticlines. The close association of bitumen and Fe-oxides and hydroxides with the U-V minerals in the LMD suggests that oilfield basin brines were present in the structures until the down cutting of the Bighorn River breached the Porcupine Creek anticline. Gypsum, dogtooth calcite, bitumen, sulfides and speleothem type occurrences from waste piles and outcrops suggest that hypogene sulfuric acid speleogenesis $[18,19]$ may have contributed to concentrating ore forming minerals in the LMD. Though underground mines are no longer safely accessible descriptions of the caves encountered and actually mined out in the LMD [6,7] support this interpretation. REE data show good correlation with the Mm hosted bitumen (Figure 9E). Hypogenic caves likely developed after oxygenated water and microbes were introduced to the system. Hydrogen sulfide that was produced by microbes consuming the light fraction of the hydrocarbons likely contributed sulfuric acid speleogenesis initiation in the LMD and to the mobilization of the metals needed to form the U-V minerals. The bitumen that was the residuum of the microbial process as well as the caves support this interpretation. The presence of Fe- and S-reducing bacteria in the Lower Kane Cave system [18] as well as U and V present in the 
mud and water of the geothermal artesian spring may serve as an analogue for the LMD. The Lower Kane Cave is actively forming by sulfuric acid speleogenesis. It has an artesian geothermal spring emanating from fractures at the core of the anticline that are mixing basin derived fluids with the groundwater at the level of the Bighorn River.

Timing of $U$ mineralization and active sulfuric acid speleogenesis in the LMD likely coincided with the timing of formation of Spence Cave in Sheep Mountain, WY, upper Kane Cave in Little Sheep Mountain, WY and the Horsethief cave formed near the mining district. Sheep Mountain and Little Sheep Mountain are anticlines that have been superposed by the Bighorn River. Each of these caves is proposed to have developed by hypogene sulfuric acid speleogenesis [92]. Windblown sand and volcanic ash that were deposited in the Spence and Horsethief caves by wind were dated using cosmogenic nuclide concentrations [92]. A cosmogenic ${ }^{26} \mathrm{Al} /{ }^{10} \mathrm{Be}$ burial date for eolian sand in the entrance to Spence Cave yielded a burial date of $0.31 \pm 0.19$ million years. Tephrochronology of ash in the Horsethief Cave is the Lava Creek B fallout ash, erupted from the Yellowstone Plateau volcanic field ca. 0.64 million years [96]. These dates may provide minimum estimates for the timing of cave development in the northern Bighorn Basin and for the U-V mineralization in the LMD.

The LMD lacks the strong silica component, barite, and fluorite that the PMD has. If the oilfield brines that originally migrated into structures had $\mathrm{F}$ from the abundant apatite it would seem likely that there should have been some present also in the LMD. This may reflect more F and Ba available from the inferred intrusion in the PMD and not as much concentration in either Ba or $\mathrm{F}$ to form barite and fluorite in the LMD. The lack of siliceous THB in the LMD may suggest the district was structurally separated from the fluids that formed the early THB in the PMD. It may also be due to less sampling in the LMD than in the PMD due to accessibility, though no barite or fluorite was observed in this study or documented in previous studies. Ba was detected in high (4300 ppm) concentration (Appendix A, No. 19) in an unmineralized breccia from the LMD though barite was not observed in the field, petrographically or using the SEM.

Although the paragenesis of each deposit examined varies, the geologic events and processes affecting Madison Limestone in the two districts have some consistent similarities. The origin of the deposits reflects a close but complex relationship with the migration of hydrocarbons, hydrology, and the exhumation of the Bighorn Basin.

\section{Future Directions}

After elevated U was identified in home water wells on the Crow Reservation collaborative research related to $U$ contaminated drinking water on the Navajo and Crow Indian Reservations was established with the University of New Mexico, the University of New Mexico and Montana State University. All three Universities are working on projects related to $U$ and the health of people on reservations. Part of the research being conducted at the University of Montana, is the development of silica polyamine composites to aid in removal of $U$ and other toxic metals from contaminated drinking water.

\subsection{Selective Solid Phase Extraction of U from Contaminated Water}

In an effort to address the long-standing health hazards imposed by abandoned uranium mines and mills, naturally occurring $U$, and trace metal contamination research is currently being conducted at the University of Montana using Silica Polyamine Composites (SPCs). SPCs filter, isolate, and remove unwanted metals. A variety of other methods such as precipitation, solvent extraction, electrolysis and ion exchange have been employed to remove dissolved metals from aqueous samples. Most of these have disadvantages such as poor removal efficiency, high cost, and generation of secondary pollutants and ineffectiveness for low concentration removal [93]. We are testing contaminated water from wells on the Navajo Reservation and using these SPCs as a potential method of remediation through various bench scale studies. Our aim is to eventually produce point of source filters that are 
economical, efficient and available to people on American Indian reservations and other areas in need of ways to clean contaminated drinking water.

Since the mid-20th century amorphous silica gels have been a favored solid-state matrix for applications in chromatography, catalysis, colloid chemistry and as drying agents [94]. SPCs are solid phase hybrid materials that consist of an inorganic matrix combined with an organic polymer developed by the Rosenberg Research Group at the University of Montana [95,96]. These hybrid materials bring together the best properties of each component in order to enhance functionality. These silica based organic-inorganic materials offer a rigid matrix with high porosity and good thermal stability [97]. Furthermore, the polar nature of the silica polyamine surface also makes for better mass-transfer kinetics in the case of aqueous solutions, and the polyamine can be easily modified with metal selective functional groups $[98,99]$. SPCs act as chelating agents for a range of metal ions and can also be useful for toxic metal immobilization and disposal [99]. They have led to a wide range of metal-selective materials that in most cases provide a high loading, rigid, surface that does not shrink or swell [97]. SPCs are currently being used in medium to large-scale recovery of metals and the remediation of toxic anionic and cationic pollutants [96,97].

Acid stripping is the primary method of extracting immobilized metals from SPCs. Without the acid strip, metals can remain on the SPC and can be used as a medium for long-term disposal [99]. These composites have been previously found to maintain activity over more than 7000 test cycles that consist of treating a packed column of SPCs with a metal ion solution and then acid stripping. These composites showed no visible signs of degradation and negligible loss in metal ion adsorption capacity under a variety of conditions [95].

SPCs are materials that are designed to bond with a specified metal and extract the metal from aqueous solutions for later recovery $[95-97,100,101]$. SPCs have the ability to be modified with a variety of metal selective ligands which is vital to an effective remediation processes. Previously the Rosenberg research group has synthesized a number of different SPCs that are selective for $\mathrm{Cu}^{2+}$, divalent transition metals, $\mathrm{Fe}^{3+}, \mathrm{Ni}^{2+}, \mathrm{Ga}^{3+}$, divalent and trivalent metals (Figure 14).

Cuselect ( $\mathrm{P}=\mathrm{PAA})$ :

selective for $\mathrm{Cu}^{2+}$

over $\mathrm{Fe}^{3+}$ at low $\mathrm{pH}$

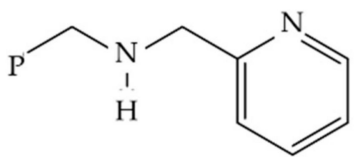

Made by reaction

with picolyl chloride or by

hydramination of pyridine 2 -

carboxaldehyde

$\mathrm{BPAP}(\mathrm{P}=\mathrm{PAA})$ : selective for trivalent over divalent metals. Highly charged metals can be immobilized for anion capture

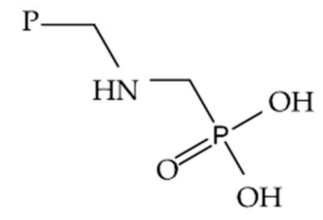

Made by Mannich Reaction with $\mathrm{CH}_{2} \mathrm{O}+$ phosphorus acid
WP-2 (P=PEI), BP-2 P=PAA):

$\mathrm{pH}$ dependent selectivity for divalent transition metals

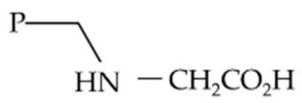

Made by reaction with chloroacetic acid

BPED (P=PAA), WPED ( $\mathrm{P}=\mathrm{PEI})$ : very selective for $\mathrm{Ni}^{2}$, over $\mathrm{Co}^{21}$, $\mathrm{Fe}^{21}, \mathrm{Zn}^{21}$

$\mathrm{P}$<smiles>CCNC(=O)CN(CCO)CCNCC(=O)O</smiles>

Made by reaction with EDTA Anhydride
WP-4 (P=PAA): selective for $\mathrm{Fe}^{3+}$ $\mathrm{Ni}^{2+}$ and $\mathrm{Ga}^{3+}$ over $\mathrm{Al}^{3+}$ ay $\mathrm{pH} \sim 2$<smiles>[X]c1cc(CNCP)c(O)c2ncccc12</smiles>

Made by Mannich Reaction with $\mathrm{CH}_{2} \mathrm{O}\left(\mathrm{X}=\mathrm{H}, \mathrm{Cl}, \mathrm{SO}_{3} \mathrm{H}\right)$

BP-NTA ( $\mathrm{P}=\mathrm{PAA}), \mathrm{WP}-\mathrm{NTA}$ ( $\mathrm{P}=\mathrm{PEI})$ : very selective for $\mathrm{Ni}^{2+}$, over $\mathrm{Co}^{2+}$, $\mathrm{Fe}^{21}, \mathrm{Zn}^{2+}$

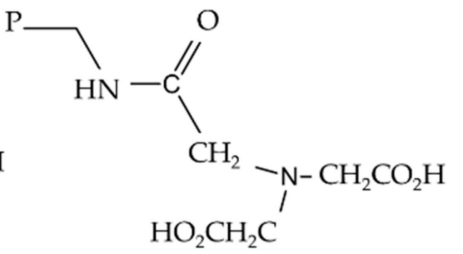

Made by Reaction with Nitrilo-acetic anhydride

Figure 14. Ligands modified Silica Polyamine Composites (SPCs) and their applications to date. 
In addition, earlier studies have evaluated the ability of SPCs to separate REE from mine leachates from Mt. Weld in Laverton, Australia. These studies separated Ce(III), La(III), Nd(III), Sm(III), and $\operatorname{Pr}(\mathrm{III})$ from the solution matrix that contained Fe(III), $\mathrm{Mn}(\mathrm{II}), \mathrm{Ca}(\mathrm{II}), \mathrm{Mg}(\mathrm{II}), \mathrm{Al}(\mathrm{III}), \mathrm{Zn}(\mathrm{II}), \mathrm{Ti}(\mathrm{IV})$, and other lower concentration trace metals [102]. This separation required first the use of WP-4 followed by BPAP. The WP-4 removed the large excess of iron and BPAP selectively removed the entire family of lanthanides from mixtures of transition metals, alkali and alkaline earth metals at low $\mathrm{pH}$ [102]. This study demonstrates the feasibility to separate REE metals from a metal matrix like that of mine leachates. Thus, if the concentration of REE or other desirable metals was economical they might be recovered using SPCs possibly offsetting the cost of remediation efforts.

\subsection{Elements of Environmental Concern}

Alluvial low lands of the Crow Reservation, MT, located along the Bighorn and Little Bighorn Rivers are where U was found to exceed EPA's MCL in some tested home wells [3]. The source of the $\mathrm{U}$ has not been determined but it is likely that material eroded from the Wolf, Big Horn and Pryor Mountain ranges may have had $U$ minerals present either from the U-V deposits, or thin Permian Phosphoria sediments. If the $\mathrm{U}$ was derived from erosion of materials associated with the U-V deposits or from Phosphoria Formation sediments then there is a possibility other metals of environmental concern e.g., $\mathrm{As}, \mathrm{Cd}, \mathrm{Hg}, \mathrm{Pb}, \mathrm{Se}$, and $\mathrm{Tl}$ may be present. $\mathrm{Tl}$ is not found in many rock types and $\mathrm{Tl}$ minerals are rare. The average crustal abundance of $\mathrm{Tl}$ is $0.75 \mathrm{ppm}$ [103]. $\mathrm{Tl}$ is one of the metals found in anomalous high concentrations in both the Phosphoria Formation and in the U-V deposits of this study. All the mineralized samples from this study contained anomalous concentrations (10-490 ppm) $\mathrm{Tl}$. $\mathrm{Tl}$ is more toxic to mammals than $\mathrm{Cd}, \mathrm{Pb}, \mathrm{Cu}$, or $\mathrm{Zn}[104,105]$. $\mathrm{Tl}$ is associated with hydrothermal sourced fluids in sediment hosted gold deposits [106-109]. Tl in these deposits was likely mobilized and transported with hydrocarbons and brines though could be related to the inferred intrusion that might also account for the $\mathrm{Au}$ and $\mathrm{Ag}$ present in the $\mathrm{U}-\mathrm{V}$ deposits. Tl disperses readily and accumulates in soil, water transport and food crops such as cabbage, affecting the health of people [110]. Tl forms highly volatile complexes with halides and can enter the crystal lattices of sulfides and sulfosalts [111]. Drinking water wells on the Crow Reservation, MT, were analyzed for Tl because U was found some of the wells tested and might be associated with the eroded material sourced from deposits in WY and MT. Initial well water samples $(n=29)$ from the Crow Reservation tested for $\mathrm{Tl}$ at the University of New Mexico did not show elevated concentrations of Tl. The results ranged from 0.01 to $0.36 \mu \mathrm{g} / \mathrm{L}$ well below the maximum contaminant level (MCL) of $0.002 \mathrm{mg} / \mathrm{L}$ and the EPA's MCLG (goal) of $0.0005 \mathrm{mg} / \mathrm{L}$ [112].

\section{Conclusions and Future Work}

$\mathrm{U}-\mathrm{V}$ mineralization is complex in the two districts. Our proposed model for paragenesis is a simplified sequence of mineralization. Both districts are hosted in the same paleokarst horizon but are in slightly different structural positions in the Bighorn Basin. The structures in both mining districts likely held hydrocarbons in structural traps until they were breached. This conclusion is based on observations of bitumen in the samples both in the field and in the lab using standard petrography, SEM, and CL techniques.

We conclude that the source of the many of the metals in the deposits of this study was likely Permian Phosphoria Formation oil introduced through fluid migration in fractures as folding proceeding during the later stages of the Laramide Orogeny. The process of episodic tectonic hydrothermal brecciation accompanied folding and provided both a mechanism and fluid source for metals in both districts. This conclusion is based on similar REE and other trace element geochemistry of: (1) the bitumen from Little Sheep Mountain; (2) the U-V breccia and gangue minerals from this study and (3) the data from Phosphoria Formation studies conducted by the USGS.

The exhumation of the Bighorn Basin affected each area differently and mineralization style and gangue minerals reflect this difference. $U$ was a later element in both districts where it followed the 
Fe-V oxides. Fe-V oxides were emplaced with the earliest siliceous THB in the PMD. The episodic nature of hydrothermal tectonic brecciation and the interaction of meteoric groundwater has created a complex mineralization sequence. The model has components of both hydrothermal and meteoric sources. It is likely that most of the $\mathrm{V}$ was hydrothermally introduced while the $\mathrm{U}$ was probably derived from both hydrothermal and meteoric sources. Especially as $\mathrm{U}^{6+}$ is very mobile in water and is still being mobilized evident by U-V minerals found on the surfaces of burned wooden supports of worked prospects in the PMD, on surfaces of reclaimed materials, along sprung stylolites and along open fractures. The triuranium carbonate minerals are generally the most soluble [85] and some are still present in the deposits. As surface water percolates through the deposits these minerals are likely dissolved and reprecipitated as the relatively insoluble metal-uranyl vanadates when encountering a V source such as material from sprung stylolites. Thus, surface waters flowing through these deposits probably do not contribute many of these elements to the hydrologic system.

This study does not support a direct source of $\mathrm{U}, \mathrm{Hg}$ or $\mathrm{Pb}$ being derived from the $\mathrm{U}-\mathrm{V}$ deposits as a source of contamination in the Bighorn River or home wells on the reservation. Though material derived from the erosion of the deposits may be a contributing factor.

$\mathrm{Hg}$ may be entering the hydrologic system through the geothermal Kane Cave system that flows directly into the Bighorn River above the Bighorn Reservoir area. Drops of oil were described in S.J. Egemeier's 1973 dissertation which helped to identify sulfuric acid speleogenesis as a cave forming process and suggested that the ore deposits might have formed through this process. Sulfate reducing bacteria present in the Kane cave system [19] may be processing the sulfate $\left(\mathrm{SO}_{4}{ }^{2-}\right)$ and also taking up mercury in its inorganic form and converting it to methylmercury through metabolic processes. The conversion of inorganic mercury to methylmercury increases the toxicity. These methylmercury-containing bacteria may be consumed by the next higher level in the food chain, or the bacteria may excrete the methylmercury to the water where it can quickly adsorb to plankton, which are also consumed by the next level in the food chain.

Thus, future work is warranted to investigate the microbial processes related to biodegradation of hydrocarbons which may show that $\mathrm{Hg}$ is indeed being introduced to the hydrologic system through these processes. The geochemical data from Table A2 shows that the mineralized U-V samples (No. 1-13) that were assayed had the highest $\mathrm{Hg}(0.179-12.8 \mathrm{ppm})$ and the select gangue minerals that were assayed for $\mathrm{Hg}$ all had detectable $\mathrm{Hg}$. These included quartz sample No. 35 (0.095 ppm); dolomite breccia sample, No. 34 (0.02 ppm); two fluorites No. 28 (0.618 ppm) and No. 29 (1.05 ppm); and calcite sample No. $26(0.034 \mathrm{ppm})$. The low concentration of $\mathrm{Hg}$ remaining in the bitumen in this study $(<0.01-0.01 \mathrm{ppm}$ samples 39-41) suggests that $\mathrm{Hg}$ was likely mobilized somewhere between the oil and bitumen phases, assuming there was a higher initial concentration in the oil. This is supported by the study [83] described earlier in the text in the section on heavy oil and bitumen. $\mathrm{Hg}$ and the other metals including the REE's do not fit in the structures of most of the minerals that contain them. This suggests that the $\mathrm{Hg}$, REE and other metals were likely incorporated as Permian Phosphoria Formation sourced hydrocarbon or brine fluid inclusions in the minerals. It is likely that $\mathrm{Hg}$ and $\mathrm{Pb}$ may be entering the hydrologic system from atmospheric anthropogenic sources as well. Future work might include: (1) tracing anthropogenic $\mathrm{Hg}$ and $\mathrm{Pb}$ input using stable $\mathrm{Hg}$ and $\mathrm{Pb}$ isotope ratios in sediments; (2) studies on how bacteria metabolize the metals of interest ( $\mathrm{Hg}$ and $\mathrm{Pb}$ ) using oils from the Garland and Elk Basin oil fields that are producing from the Mississippian and Pennsylvanian reservoir rocks in the northern Bighorn Basin; and (3) using portable DNA analyzers in some of the hydrothermal springs entering the Bighorn River area to identify different bacteria that may be metabolizing the metals.

Water quality on many reservations will undoubtedly continue to be an issue. Research will be continued to develop a way to remove $U$ and other metals from the water to ensure the most important need on the Navajo, Crow, and other reservations, clean water for good health. 
Acknowledgments: We thank employees of the Bureau of Land Management, Cody, Wyoming, who granted permission for the work in the Little Mountain area. Lauren Kay, Janet Barkow, and Thomas H. Nall for fieldwork assistance. Chris Gammons and Gary Wyss, Montana Tech, Butte, MT, for use of their facilities and analytical work and discussions related to this project. Funding for research: ZERT II (Zero Emissions Research) DOE Award \#: DE-FE0000397; Alfred P. Sloan Graduate Scholarship Programs-Sloan Indigenous Graduate Partnership; Montana State University-Dennis and Phyllis Washington Foundation Native American Graduate Fellow; HOPA Mountain Program; EPA STAR (Environmental Protection Agency's Science to Achieve Results) grant FP-91779501-0 and ISTEM grant NSF1348410. Note: The content is solely the responsibility of the authors; it has not been formally reviewed by any of the funders.

Author Contributions: Anita L. Moore-Nall: Researched the area's geology, did the field work, submitted samples, interpreted the geological and geochemical data, produced most of the figures and is primary author on paper; Ranalda L. Tsosie: Researched, did the chemistry and wrote the Selective Solid Phase Extraction of Uranium portion of the paper; reviewed drafts of the paper; contributed to the manuscript.

Conflicts of Interest: The authors declare no conflict of interest. The founding sponsors had no role in the design of the study; in the collection, analyses, or interpretation of data; in the writing of the manuscript, and in the decision to publish the results.

\section{Appendix A}

Five samples were analyzed for platinum group metals (PGM) and Au by Fire Assay with ICP finish by American Analytical Services (AAS), Osburn, ID, USA. The samples included two U-V mineralized breccia, two barites, and a fluorite. Table A1 shows these results. Values are in ppm.

Table A1. PGM and Au Results American Analytical Services (AAS) laboratory.

\begin{tabular}{cccccc}
\hline \multirow{2}{*}{ Element } & Sandra713B & DandyF & FS142 & FS131 & OGMB \\
\cline { 2 - 6 } & U-V-Mineral & Fluorite & Barite & U-V-Mineral & Barite \\
\hline $\mathrm{Pt}$ & $<0.020$ & $<0.020$ & na & $<0.020$ & na \\
$\mathrm{Pd}$ & $<0.020$ & $<0.020$ & na & $<0.020$ & na \\
$\mathrm{Rh}$ & $<0.020$ & $<0.020$ & na & $<0.020$ & na \\
$\mathrm{Au}$ & 0.031 & 0.067 & $<0.005$ & 0.055 & 2.35 \\
\hline
\end{tabular}

The Nevada branch of Australian Laboratory Services (ALS) Global analyzed samples for REE and trace elements. A total of 41 samples were analyzed: $18 \mathrm{U}-\mathrm{V}$ mineralized breccia, 6 limestone and dolomite host rock, 5 calcite, 1 bentonite, 1 barite, 5 fluorite, and 4 quartz were analyzed for REE by by Lithium Borate Fusion and ICP-MS (Fused bead, acid digestion and ICP-MS) in a 30 element package (ME-MS81). Three samples containing bitumen were analyzed for REE by Aqua Regia and ICP-AES/ICP-MS (ME-MS41r) a 51-element package. Twenty two samples were analyzed for base metals by a four acid digestion and ICP-MS (ME-4ACD81) to test for Pb and 17 samples were analyzed for trace element $\mathrm{Hg}$ by Aqua Regia and ICP-MS (Hg-MS42). Additionally 17 mineralized samples were analyzed by by XRF (V,U-XRF10) for ore grade $\% \mathrm{U}$ and 3 for ore grade $\% \mathrm{~V}$ as these samples were above the maximum detection level using ME-MS81. Trace element data is presented in Table A2 and REE data is presented in Table A3. 


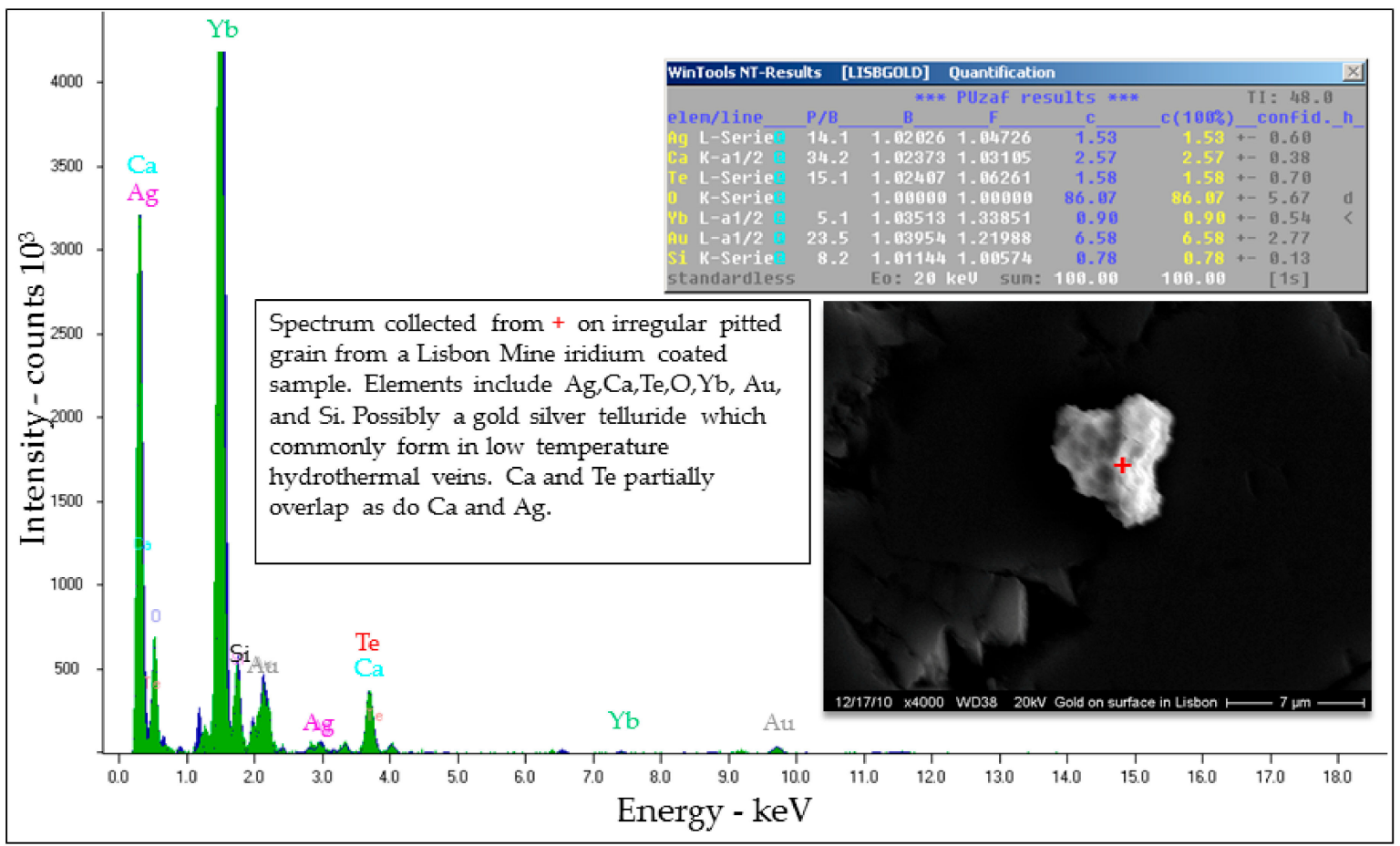

Figure A1. EDS spectrum of Au mineral from Lisbon mine sample. The Y-axis shows the counts in $10^{3}$ (number of $\mathrm{X}$-rays received and processed by the detector) and the $\mathrm{X}$-axis shows the energy level of those counts in kilo-electron volts $(\mathrm{keV})$. 
Table A2. Other metals analyzed by ALS laboratory results with samples listed across the top of the table and elements to the left side. The first 18 samples are mineralized breccia samples. The next 23 samples are the host rock, gangue minerals and unmineralized breccia samples. Values with $<$ indicate the value was below the detection limit of the analysis and (na) = not analyzed. Values are in ppm.

\begin{tabular}{|c|c|c|c|c|c|c|c|c|c|c|c|c|c|c|c|}
\hline No. & Sample & Ag & As & Ba & $\mathrm{Cd}$ & Co & $\mathrm{Cr}$ & Cs & $\mathrm{Cu}$ & $\mathrm{Fe}$ & $\mathrm{Ga}$ & Hf & $\mathrm{Hg}$ & $\mathbf{L i}$ & Mo \\
\hline 1 & FS131A U-V breccia & 1.3 & 262 & 1230 & 1.7 & $<1$ & $<10$ & 0.63 & $<1$ & na & 3.4 & $<0.2$ & 2.84 & $<10$ & 53 \\
\hline 2 & LMLisbon U-V breccia & $<0.5$ & 89 & 42.6 & 0.9 & 9 & $<10$ & 0.37 & 94 & na & 28.2 & $<0.2$ & 0.197 & $<10$ & 25 \\
\hline 3 & Swamp Frog U-V breccia & 1.3 & 556 & 1320 & $<0.5$ & 1 & 20 & 1.65 & 7 & na & 7.5 & 0.6 & 0.396 & 20 & 791 \\
\hline 4 & SBRX01 U-V breccia & $<0.5$ & 49 & 5460 & $<0.5$ & 8 & 100 & 1.64 & 4 & na & 9.5 & $<0.2$ & 0.333 & 30 & 11 \\
\hline 5 & LMLeo02 U-V breccia & $<0.5$ & 726 & 255 & 3.8 & 70 & 20 & 0.77 & 109 & na & 43.1 & 0.7 & 0.179 & 10 & 137 \\
\hline 6 & MarieMine001 U-V breccia & $<0.5$ & 87 & 533 & 2.6 & $<1$ & 60 & 1.9 & $<1$ & na & 7.7 & 3.1 & 1.715 & 10 & 319 \\
\hline 7 & Perc01 U-V breccia & $<0.5$ & 329 & 5170 & $<0.5$ & $<1$ & 10 & 1.2 & 6 & na & 8.7 & $<0.2$ & 1.21 & 10 & 52 \\
\hline 8 & OGM04 U-V breccia & $<0.5$ & 1295 & 2310 & 0.5 & 7 & 40 & 0.84 & 12 & na & 10.6 & 0.6 & 0.354 & 10 & 152 \\
\hline 9 & P005 U-V breccia & $<0.5$ & 1080 & 1305 & $<0.5$ & 9 & 50 & 1.24 & 2 & na & 15.4 & 2.3 & 1.255 & 10 & 386 \\
\hline 10 & Sandra713B U-V breccia & $<0.5$ & 99 & 6550 & 0.5 & 6 & 240 & 1.63 & 14 & na & 42.1 & $<0.2$ & 1.485 & 40 & 29 \\
\hline 11 & D2001 U-V breccia & $<0.5$ & 87 & 79.5 & 3.2 & $<1$ & $<10$ & 0.36 & $<1$ & na & 6 & $<0.2$ & 6.32 & $<10$ & 9 \\
\hline 12 & DandyMSPF U-V breccia & $<0.5$ & 30 & 39.6 & 0.5 & $<1$ & 10 & 0.24 & $<1$ & na & 2.2 & $<0.2$ & 3.4 & $<10$ & 4 \\
\hline 13 & DandyMBr U-V breccia & $<0.5$ & 130 & 61.3 & 1.7 & 5 & 10 & 0.78 & $<1$ & na & 10.4 & 0.2 & 12.8 & 10 & 28 \\
\hline 14 & OGM UV blk U-V breccia & 0.5 & 46 & 1530 & $<0.5$ & 12 & 10 & 0.78 & 1 & na & 2 & 0.3 & na & $<10$ & 21 \\
\hline 15 & DandyMSP U-V breccia & $<0.5$ & 94 & 2470 & $<0.5$ & 37 & 10 & 5.42 & 5 & na & 4.6 & 0.5 & na & 10 & 20 \\
\hline 16 & EP001 U-V breccia & $<0.5$ & 50 & 27.6 & 0.9 & 7 & 10 & 0.46 & 2 & na & 1.7 & 0.4 & na & $<10$ & 2 \\
\hline 17 & LMLeoIncline U-V breccia & $<0.5$ & 116 & 183 & 2.1 & 22 & 10 & 0.21 & 90 & na & 11.8 & 0.3 & na & $<10$ & 98 \\
\hline 18 & LMLisbonBX U-V breccia & $<0.5$ & 212 & 140 & 0.6 & 22 & 10 & 0.66 & 17 & na & 9.3 & 0.4 & na & $<10$ & 93 \\
\hline 19 & LMLisbonSB shatter breccia & na & na & 4330 & na & na & 10 & 0.14 & na & na & 0.7 & $<0.2$ & na & na & na \\
\hline 20 & EP001DB dark breccia & na & na & 29.2 & na & na & 20 & 0.36 & na & na & 1.2 & 0.2 & na & na & na \\
\hline 21 & SWMP_H host limestone & na & na & 9.7 & na & na & 10 & 0.11 & na & na & 0.6 & $<0.2$ & na & na & na \\
\hline 22 & Sandra002 limestone & na & na & 23.2 & na & na & 10 & 0.05 & na & na & 0.8 & $<0.2$ & na & na & na \\
\hline 23 & UMB018 silicified breccia & na & na & 6.5 & na & na & 10 & 0.02 & na & na & 1 & $<0.2$ & na & na & na \\
\hline 24 & FS139 calcite & na & na & 16.5 & na & na & 10 & 0.05 & na & na & 0.5 & 0.2 & na & na & na \\
\hline 25 & BPM_BC speleothem calcite & na & na & 46.9 & na & na & $<10$ & 0.02 & na & na & 0.3 & $<0.2$ & na & na & na \\
\hline 26 & BCS speleothem calcite & $<0.5$ & $<5$ & 24 & $<0.5$ & 9 & $<10$ & 0.03 & 3 & na & 0.3 & $<0.2$ & 0.034 & $<10$ & 2 \\
\hline 27 & LeoGC calcite & na & na & 24.2 & na & na & $<10$ & 0.02 & na & na & 1 & $<0.2$ & na & na & na \\
\hline 28 & Dandy Mine fluorite & $<0.5$ & 22 & 29.7 & $<0.5$ & 3 & 10 & 0.17 & $<1$ & na & 1.1 & $<0.2$ & 0.618 & $<10$ & 8 \\
\hline 29 & MarieF fluorite & $<0.5$ & 64 & 72 & 0.5 & 8 & 20 & 0.37 & $<1$ & na & 2.4 & 0.2 & 1.05 & 10 & 10 \\
\hline 30 & EPryorF fluorite & na & na & 729 & na & na & 40 & 0.51 & na & na & 2.1 & 0.3 & na & na & na \\
\hline 31 & DandyF fluorite & na & na & 331 & na & na & 30 & 0.5 & na & na & 2 & 0.3 & na & na & na \\
\hline 32 & SandraF fluorite & na & na & 9.7 & na & na & 10 & 0.15 & na & na & 1 & $<0.2$ & na & na & na \\
\hline 33 & SWMP_B barite & na & na & $>10,000$ & na & na & 20 & 0.47 & na & na & 2.1 & 0.4 & na & na & na \\
\hline
\end{tabular}


Table A2. Cont.

\begin{tabular}{|c|c|c|c|c|c|c|c|c|c|c|c|c|c|c|c|}
\hline No. & Sample & Ag & As & $\mathbf{B a}$ & $\mathrm{Cd}$ & Co & $\mathrm{Cr}$ & Cs & $\mathrm{Cu}$ & $\mathrm{Fe}$ & $\mathrm{Ga}$ & Hf & $\mathrm{Hg}$ & $\mathbf{L i}$ & Mo \\
\hline 34 & Lisbon001-dolomite breccia & $<0.5$ & $<5$ & 200 & $<0.5$ & 3 & 20 & 1.65 & 1 & na & 3.7 & 1 & 0.02 & 10 & 2 \\
\hline 35 & LisbonQP quartz w/pyrite & $<0.5$ & $<5$ & 87.5 & $<0.5$ & 18 & $<10$ & 0.05 & 1 & na & 1 & $<0.2$ & 0.095 & $<10$ & 1 \\
\hline 36 & GS32 quartz & na & na & 264 & na & na & 10 & 0.04 & na & na & 1.2 & $<0.2$ & na & na & na \\
\hline 37 & TS-53 quartz & na & na & 562 & na & na & $<10$ & 0.14 & na & na & 1.1 & 0.2 & na & na & na \\
\hline 38 & Bentonite & $<0.5$ & 6 & 597 & $<0.5$ & 3 & $<10$ & 0.86 & 2 & na & 24 & 7.8 & $<0.005$ & 20 & 1 \\
\hline 39 & Mm hosted bitumen & 0.05 & 0.2 & 10 & 0.05 & 9.9 & 1 & 0.06 & 3 & 300 & $<0.05$ & $<0.02$ & 0.01 & 0.5 & 1.63 \\
\hline 40 & Mm breccia hosted bitumen & 0.01 & $<0.1$ & 20 & 0.1 & 0.9 & $<1$ & $<0.05$ & 1.2 & 500 & $<0.05$ & $<0.02$ & $<0.01$ & 0.1 & 0.12 \\
\hline 41 & Goose Egg hosted bitumen & 0.01 & 1 & 630 & 0.08 & 2.4 & 1 & 0.06 & 2.8 & 800 & 0.21 & $<0.02$ & 0.01 & 2.2 & 0.46 \\
\hline No. & Sample & $\mathbf{P b}$ & $\mathbf{R b}$ & Sc & Se & Sn & $\mathrm{Sr}$ & Ta & Th & $\mathrm{Tl}$ & $\mathbf{U}$ & V & $\mathbf{W}$ & Zn & $\mathrm{Zr}$ \\
\hline 1 & FS131A U-V breccia & $<2$ & 1.5 & 4 & na & $<1$ & 257 & $<0.1$ & 0.66 & 180 & 86,800 & 18,900 & 94 & 16 & 4 \\
\hline 2 & LMLisbon U-V breccia & 146 & 5.9 & 1 & na & 4 & 261 & $<0.1$ & 0.09 & 30 & 31,100 & 8520 & 11 & 1300 & 2 \\
\hline 3 & Swamp Frog U-V breccia & $<2$ & 13 & 3 & na & 1 & 192.5 & 0.1 & 1.3 & 340 & 6100 & 4160 & 81 & 44 & 23 \\
\hline 4 & SBRX01 U-V breccia & 7 & 4.4 & 8 & na & $<1$ & 182.5 & $<0.1$ & 0.16 & 10 & 2600 & 1950 & 71 & 136 & 2 \\
\hline 5 & LMLeo02 U-V breccia & 57 & 5.5 & 2 & na & 7 & 401 & 0.1 & 1.27 & 230 & 16,000 & 10,300 & 11 & 2230 & 29 \\
\hline 6 & MarieMine001 U-V breccia & $<2$ & 18.1 & 6 & na & 1 & 62.5 & 0.2 & 6.57 & 30 & 2100 & 6740 & 40 & 57 & 128 \\
\hline 7 & Perc01 U-V breccia & 51 & 3 & 12 & na & $<1$ & 227 & $<0.1$ & 0.24 & 170 & 20,700 & 6700 & 30 & 95 & 4 \\
\hline 8 & OGM04 U-V breccia & 13 & 4.8 & 9 & na & 1 & 1355 & 0.1 & 1.12 & 100 & 10,600 & 4410 & 105 & 26 & 22 \\
\hline 9 & P005 U-V breccia & 18 & 9.7 & 9 & na & 2 & 980 & 0.4 & 6.12 & 340 & 9000 & 6010 & 19 & 165 & 91 \\
\hline 10 & Sandra713B U-V breccia & 44 & 14.8 & 39 & na & 1 & 188.5 & $<0.1$ & 0.55 & 20 & 21,400 & 8730 & 24 & 804 & 4 \\
\hline 11 & D2001 U-V breccia & 35 & 2 & 1 & na & 1 & 132.5 & $<0.1$ & 0.15 & 50 & 17,700 & 6310 & 16 & 849 & 2 \\
\hline 12 & DandyMSPF U-V breccia & 8 & 2.7 & 2 & na & $<1$ & 128 & $<0.1$ & 0.25 & 10 & 3000 & 3320 & 12 & 76 & 5 \\
\hline 13 & DandyMBr U-V breccia & 55 & 6.4 & 4 & na & $<1$ & 147.5 & $<0.1$ & 0.5 & 20 & 28,100 & 10,500 & 26 & 1110 & 10 \\
\hline 14 & OGM UV blk U-V breccia & 2 & 6.4 & 1 & na & $<1$ & 110 & 0.1 & 0.36 & 50 & 4900 & 1240 & 107 & 7 & 12 \\
\hline 15 & DandyMSP U-V breccia & 35 & 31.5 & 5 & na & 6 & 513 & 0.3 & 0.94 & 490 & 8600 & 2220 & 382 & 9 & 20 \\
\hline 16 & EP001 U-V breccia & 11 & 6.7 & 2 & na & $<1$ & 84.7 & $<0.1$ & 0.63 & 10 & 907 & 25 & 6 & 143 & 18 \\
\hline 17 & LMLeoIncline U-V breccia & 28 & 2.4 & 1 & na & 10 & 168.5 & $<0.1$ & 0.73 & 20 & $>1000$ & 4330 & 13 & 970 & 16 \\
\hline 18 & LMLisbonBX U-V breccia & 4 & 5.5 & 1 & na & 10 & 151.5 & $<0.1$ & 0.55 & 10 & 1300 & 1850 & 12 & 569 & 15 \\
\hline 19 & LMLisbonSB shatter breccia & na & 2.3 & na & na & $<1$ & 191 & 0.1 & 0.19 & na & 32.7 & 164 & 13 & na & 4 \\
\hline 20 & EP001DB dark breccia & na & 4.5 & na & na & $<1$ & 105 & 0.1 & 0.35 & na & 407 & 28 & 28 & na & 7 \\
\hline 21 & SWMP_H host limestone & na & 1.5 & na & na & $<1$ & 108 & $<0.1$ & 0.15 & na & 3.07 & 7 & 10 & na & 5 \\
\hline 22 & Sandra002 limestone & na & 0.5 & na & na & $<1$ & 158.5 & $<0.1$ & 0.1 & na & 0.52 & 6 & 4 & na & 4 \\
\hline 23 & UMB018 silicified breccia & na & 0.2 & na & na & $<1$ & 63.5 & $<0.1$ & $<0.05$ & na & 3.02 & 12 & 23 & na & $<2$ \\
\hline 24 & FS139 calcite & na & 0.9 & na & na & $<1$ & 97.8 & $<0.1$ & 0.15 & na & 25.1 & 123 & 10 & na & 11 \\
\hline 25 & BPM_BC speleothem calcite & na & $<0.2$ & na & na & $<1$ & 43.2 & $<0.1$ & $<0.05$ & na & 14.8 & $<5$ & 4 & na & $<2$ \\
\hline
\end{tabular}


Table A2. Cont.

\begin{tabular}{|c|c|c|c|c|c|c|c|c|c|c|c|c|c|c|c|}
\hline No. & Sample & $\mathrm{Pb}$ & $\mathbf{R b}$ & $\mathrm{Sc}$ & Se & Sn & Sr & Ta & Th & $\mathrm{Tl}$ & $\mathbf{U}$ & $\mathbf{V}$ & W & Zn & $\mathrm{Zr}$ \\
\hline 26 & BCS speleothem calcite & 2 & 0.2 & $<1$ & na & $<1$ & 590 & 0.1 & $<0.05$ & $<10$ & 43.3 & 20 & 47 & 15 & $<2$ \\
\hline 27 & LeoGC green calcite & na & 0.5 & na & na & $<1$ & 174.5 & $<0.1$ & 0.09 & na & 159 & 268 & 9 & na & 2 \\
\hline 28 & Dandy Mine fluorite & 3 & 1.7 & 3 & na & 1 & 26.1 & $<0.1$ & 0.66 & $<10$ & 518 & 439 & 14 & 41 & 5 \\
\hline 29 & MarieF fluorite & 3 & 3.8 & 3 & na & 1 & 33.7 & 0.1 & 0.7 & $<10$ & 842 & 871 & 25 & 65 & 7 \\
\hline 30 & EPryorF fluorite & na & 8.2 & na & na & $<1$ & 132 & 0.1 & 1.14 & na & 87.7 & 51 & 23 & na & 13 \\
\hline 31 & DandyF fluorite & na & 7.7 & na & na & $<1$ & 44.1 & 0.1 & 0.65 & na & 105 & 542 & 18 & na & 11 \\
\hline 32 & SandraF fluorite & na & 2 & na & na & $<1$ & 52.4 & $<0.1$ & 0.67 & na & 53.4 & 655 & 1 & na & 4 \\
\hline 33 & SWMP_B barite & na & 5.6 & na & na & 1 & 8260 & 0.1 & 1.15 & na & 15.2 & 195 & 11 & na & 14 \\
\hline 34 & Lisbon001 dolomite breccia & 2 & 25.9 & 2 & na & $<1$ & 116.5 & 0.2 & 2.09 & $<10$ & 6.75 & 25 & 11 & 17 & 42 \\
\hline 35 & LisbonQP quartz w/pyrite & $<2$ & 1.2 & $<1$ & na & $<1$ & 14.2 & 0.2 & 0.09 & $<10$ & 1.34 & $<5$ & 199 & $<2$ & 3 \\
\hline 36 & GS32 quartz & na & 0.5 & na & na & $<1$ & 12.2 & 0.1 & 0.06 & na & 27.7 & 17 & 209 & na & 6 \\
\hline 37 & TS-53 quartz & na & 1.4 & na & na & $<1$ & 33.7 & 0.2 & 0.21 & na & 25.3 & 26 & 279 & na & 12 \\
\hline 38 & Bentonite & 32 & 20.1 & 2 & na & 7 & 381 & 2.3 & 32.1 & $<10$ & 56.7 & 22 & 6 & 64 & 245 \\
\hline 39 & Mm hosted bitumen & 0.9 & 0.4 & 0.1 & 3.2 & 3.2 & 76.4 & $<0.01$ & $<0.2$ & 0.02 & 6.8 & 73 & 8.63 & 5 & $<0.5$ \\
\hline 40 & Mm breccia hosted bitumen & 0.5 & 0.1 & 0.1 & 0.5 & 0.5 & 156 & $<0.01$ & $<0.2$ & $<0.02$ & 4.04 & 7 & 2.38 & 2 & $<0.5$ \\
\hline 41 & Goose Egg hosted bitumen & 1.5 & 0.8 & 0.1 & 0.5 & 0.5 & 2720 & $<0.01$ & $<0.2$ & 0.03 & 11.6 & 8 & 20.8 & 9 & 0.5 \\
\hline
\end{tabular}

Table A3. REE plus Y ALS laboratory results with samples listed across the top of the table and elements to the side. The first 18 samples are mineralized breccia samples. The next 23 samples are the host rock, gangue minerals and unmineralized breccia samples. Values with $<$ indicate the value was below the detection limit of the analysis. Values are in ppm.

\begin{tabular}{|c|c|c|c|c|c|c|c|c|c|c|c|c|c|c|c|c|}
\hline No. & Sample Number & La & $\mathrm{Ce}$ & $\operatorname{Pr}$ & $\mathrm{Nd}$ & $\mathrm{Sm}$ & Eu & Gd & $\mathbf{T b}$ & Dy & Ho & Er & $\mathrm{Tm}$ & $\mathbf{Y b}$ & Lu & $\mathbf{Y}$ \\
\hline 1 & FS131A U-V breccia & 0.9 & 5.9 & 1 & 6.6 & 3.54 & 1.06 & 4.76 & 1.21 & 7.92 & 1.45 & 4.26 & 0.53 & 3.46 & 0.42 & 33.1 \\
\hline 2 & LMLisbon U-V breccia & 9.5 & 13.9 & 1.86 & 7.9 & 1.66 & 0.4 & 2.08 & 0.3 & 1.85 & 0.39 & 1.13 & 0.12 & 0.76 & 0.12 & 17 \\
\hline 3 & Swamp Frog U-V breccia & 4.5 & 21.2 & 2.03 & 9 & 2.09 & 0.41 & 1.28 & 0.16 & 0.72 & 0.13 & 0.32 & 0.05 & 0.36 & 0.03 & 2.8 \\
\hline 4 & SBRX01 U-V breccia & 6.7 & 24.7 & 5.57 & 32.5 & 12.25 & 3.51 & 19.1 & 3.07 & 18.55 & 3.92 & 10.65 & 1.32 & 7.21 & 1.02 & 172 \\
\hline 5 & LMLeo02 U-V breccia & 10.1 & 18.6 & 2.37 & 9.6 & 2.05 & 0.53 & 2.32 & 0.37 & 2.03 & 0.43 & 1.29 & 0.16 & 1.02 & 0.14 & 15.6 \\
\hline 6 & MarieMine001 U-V breccia & 9.7 & 32.4 & 4.96 & 26.9 & 6.97 & 1.2 & 3.54 & 0.38 & 1.68 & 0.33 & 1.05 & 0.14 & 0.93 & 0.12 & 7.6 \\
\hline 7 & Perc01 U-V breccia & 10.7 & 52.7 & 4.29 & 19 & 3.87 & 0.81 & 3.46 & 0.48 & 2.53 & 0.46 & 1.06 & 0.13 & 0.9 & 0.11 & 17.4 \\
\hline 8 & OGM04 U-V breccia & 13.7 & 44.5 & 8.2 & 40.9 & 8.88 & 1.69 & 5.76 & 0.95 & 5.7 & 0.96 & 2.56 & 0.4 & 3.17 & 0.32 & 21.3 \\
\hline 9 & P005 U-V breccia & 22.3 & 54.3 & 8.21 & 35.2 & 7.19 & 1.76 & 8.33 & 1.33 & 8.28 & 1.76 & 4.94 & 0.61 & 4.11 & 0.57 & 65 \\
\hline 10 & Sandra713B U-V breccia & 44.8 & 222 & 44.1 & 245 & 76.5 & 20.6 & 103 & 15.4 & 87.7 & 17.85 & 46.9 & 5.55 & 33.3 & 4.45 & 840 \\
\hline 11 & D2001 U-V breccia & 1.5 & 3.9 & 0.49 & 2.4 & 0.75 & 0.17 & 0.84 & 0.14 & 0.9 & 0.19 & 0.41 & 0.07 & 0.34 & 0.03 & 10.4 \\
\hline 12 & DandyMSPF U-V breccia & 2.1 & 5.3 & 0.95 & 4.8 & 1.46 & 0.43 & 2.39 & 0.36 & 2.06 & 0.49 & 1.3 & 0.12 & 0.74 & 0.09 & 19.8 \\
\hline
\end{tabular}


Table A3. Cont.

\begin{tabular}{|c|c|c|c|c|c|c|c|c|c|c|c|c|c|c|c|c|}
\hline No. & Sample Number & La & $\mathrm{Ce}$ & Pr & Nd & Sm & Eu & Gd & $\mathrm{Tb}$ & Dy & Ho & Er & $\mathrm{Tm}$ & $\mathbf{Y b}$ & Lu & $\mathrm{Y}$ \\
\hline 13 & DandyMBr U-V breccia & 4.8 & 15 & 2.44 & 13.3 & 4.7 & 1.38 & 7.52 & 1.33 & 8.12 & 1.74 & 4.51 & 0.61 & 3.41 & 0.47 & 70.6 \\
\hline 14 & OGM UV blk U-V breccia & 1.6 & 3.8 & 0.38 & 1.6 & 0.55 & 0.1 & 0.27 & 0.05 & 0.3 & 0.05 & 0.08 & 0.02 & 0.17 & 0.01 & 1 \\
\hline 15 & DandyMSP U-V breccia & 13.7 & 40.6 & 8.46 & 43.8 & 8.45 & 1.6 & 4.7 & 0.98 & 5.91 & 0.77 & 1.94 & 0.31 & 2.53 & 0.17 & 12.3 \\
\hline 16 & EP001 U-V breccia & 2.8 & 5.7 & 0.74 & 3.5 & 0.8 & 0.17 & 1.06 & 0.16 & 1.09 & 0.26 & 0.7 & 0.11 & 0.6 & 0.09 & 8.5 \\
\hline 17 & LMLeoIncline U-V breccia & 5.2 & 10.4 & 1.31 & 5.4 & 0.98 & 0.3 & 1.35 & 0.21 & 1.16 & 0.27 & 0.57 & 0.1 & 0.47 & 0.07 & 8.9 \\
\hline 18 & LMLisbonBX U-V breccia & 3.4 & 6.1 & 0.82 & 3.5 & 0.51 & 0.14 & 0.6 & 0.08 & 0.51 & 0.11 & 0.36 & 0.04 & 0.24 & 0.03 & 4.3 \\
\hline 19 & LMLisbonSB shatter breccia & 0.9 & 1.4 & 0.18 & 0.7 & 0.14 & $<0.03$ & 0.13 & 0.02 & 0.12 & 0.02 & 0.05 & 0.01 & 0.05 & 0.01 & 0.5 \\
\hline 20 & EP001DB dark breccia & 1.3 & 2.7 & 0.39 & 1.7 & 0.39 & 0.09 & 0.5 & 0.06 & 0.38 & 0.08 & 0.26 & 0.03 & 0.23 & 0.03 & 3.2 \\
\hline 21 & SWMP_H host limestone & 1.1 & 1.4 & 0.21 & 0.9 & 0.12 & $<0.03$ & 0.15 & 0.02 & 0.12 & 0.03 & 0.1 & 0.01 & 0.11 & 0.02 & 1.3 \\
\hline 22 & Sandra002 limestone & 1.1 & 1.4 & 0.22 & 1 & 0.16 & $<0.03$ & 0.18 & 0.03 & 0.18 & 0.05 & 0.15 & 0.02 & 0.12 & 0.03 & 2.4 \\
\hline 23 & UMB018 silicified breccia & 2.3 & 4 & 0.65 & 2.7 & 0.57 & 0.14 & 0.67 & 0.09 & 0.58 & 0.12 & 0.39 & 0.05 & 0.24 & 0.05 & 4.9 \\
\hline 24 & FS139 calcite & 2.30 & 4.20 & 0.41 & 2.00 & 0.44 & 0.07 & 0.53 & 0.09 & 0.47 & 0.13 & 0.43 & 0.04 & 0.37 & 0.06 & 4.30 \\
\hline 25 & BPM_BC speleothem calcite & $<0.5$ & $<0.5$ & $<0.03$ & 0.10 & $<0.03$ & $<0.03$ & $<0.5$ & $<0.01$ & $<0.5$ & $<0.01$ & $<0.03$ & $<0.01$ & $<0.03$ & 0.01 & $<0.5$ \\
\hline 26 & BCS speleothem calcite & $<0.5$ & $<0.5$ & 0.03 & 0.10 & $<0.03$ & $<0.03$ & $<0.5$ & $<0.01$ & $<0.5$ & $<0.01$ & $<0.03$ & $<0.01$ & $<0.03$ & $<0.01$ & $<0.5$ \\
\hline 27 & LeoGC green calcite & 0.60 & 0.80 & 0.08 & 0.30 & 0.04 & $<0.03$ & 0.05 & 0.01 & $<0.5$ & $<0.01$ & $<0.03$ & 0.01 & $<0.03$ & 0.01 & $<0.5$ \\
\hline 28 & Dandy Mine fluorite & 2.70 & 6.40 & 1.11 & 5.80 & 1.78 & 0.50 & 2.85 & 0.49 & 2.63 & 0.57 & 1.52 & 0.20 & 1.21 & 0.17 & 35.90 \\
\hline 29 & MarieF fluorite & 3.00 & 9.50 & 1.81 & 11.20 & 3.84 & 0.96 & 5.06 & 0.72 & 3.57 & 0.70 & 1.89 & 0.23 & 1.45 & 0.19 & 35.20 \\
\hline 30 & EPryorF fluorite & 4.90 & 9.60 & 1.41 & 6.90 & 1.76 & 0.49 & 3.09 & 0.47 & 2.69 & 0.60 & 1.50 & 0.20 & 1.24 & 0.16 & 35.10 \\
\hline 31 & DandyF fluorite & 2.00 & 4.00 & 0.50 & 2.50 & 0.64 & 0.19 & 1.01 & 0.19 & 1.04 & 0.21 & 0.57 & 0.07 & 0.41 & 0.07 & 11.80 \\
\hline 32 & SandraF fluorite & 2.00 & 4.30 & 0.66 & 3.30 & 0.85 & 0.18 & 0.98 & 0.15 & 0.90 & 0.17 & 0.45 & 0.06 & 0.34 & 0.06 & 8.80 \\
\hline 33 & SWMP_B barite & 5.60 & 4.30 & 0.66 & 3.80 & 3.43 & $<0.03$ & 0.89 & 0.09 & 0.38 & 0.09 & 0.16 & 0.04 & 0.52 & 0.16 & 3.00 \\
\hline 34 & Lisbon001-dolomite breccia & 6.70 & 12.70 & 1.44 & 6.10 & 1.05 & 0.22 & 1.04 & 0.16 & 0.88 & 0.21 & 0.58 & 0.07 & 0.56 & 0.09 & 5.10 \\
\hline 35 & LisbonQP quartz w/pyrite & $<0.5$ & 0.70 & 0.10 & 0.40 & 0.11 & $<0.03$ & 0.16 & 0.02 & 0.08 & 0.02 & 0.06 & 0.01 & 0.04 & 0.02 & 0.50 \\
\hline 36 & GS32 quartz & $<0.5$ & 0.60 & 0.08 & 0.40 & 0.07 & $<0.03$ & 0.16 & 0.01 & 0.08 & 0.02 & 0.05 & $<0.01$ & 0.03 & 0.01 & 0.80 \\
\hline 37 & TS-53 quartz & 0.60 & 1.30 & 0.16 & 0.60 & 0.09 & $<0.03$ & 0.21 & 0.04 & 0.27 & 0.07 & 0.22 & 0.04 & 0.22 & 0.03 & 2.20 \\
\hline 38 & Bentonite & 51.10 & 96.20 & 10.20 & 35.60 & 6.19 & 0.70 & 4.50 & 0.64 & 3.61 & 0.69 & 1.96 & 0.26 & 1.92 & 0.28 & 16.30 \\
\hline 39 & Mm hosted bitumen & 0.50 & 1.28 & 0.16 & 0.80 & 0.18 & 0.04 & 0.20 & 0.03 & 0.16 & 0.03 & 0.08 & 0.01 & 0.05 & 0.01 & 1.07 \\
\hline 40 & Mm breccia hosted bitumen & 1.80 & 3.70 & 0.44 & 2.00 & 0.42 & 0.09 & 0.54 & 0.08 & 0.42 & 0.08 & 0.22 & 0.03 & 0.15 & 0.02 & 2.88 \\
\hline 41 & Goose Egg hosted bitumen & 3.00 & 2.20 & 1.70 & 1.30 & 0.70 & $<0.03$ & 0.50 & 0.30 & 0.30 & 0.40 & 0.30 & 0.40 & 0.20 & $<0.01$ & 3.00 \\
\hline
\end{tabular}




\section{Appendix B}

\section{Selected EDS Analyses and Figures from This Study}

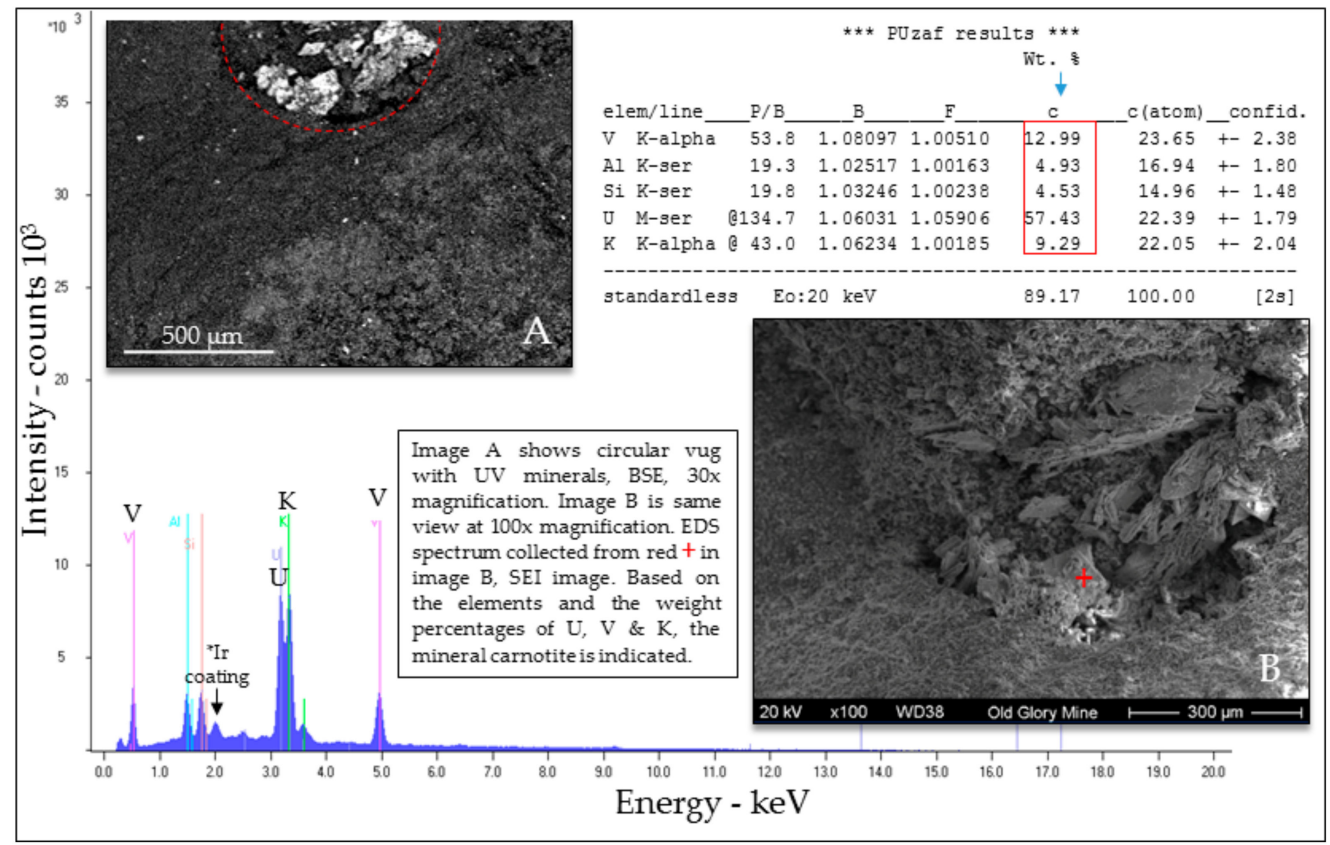

Figure A2. Image A in figure shows Old Glory mine silicified breccia sample with U-V minerals in a vug. Image B is a higher magnification of Image A. The EDS spectrum was collected from + in Image B. Carnotite is indicated based on the empirical formula $\mathrm{K}_{2}\left(\mathrm{UO}_{2}\right)_{2}\left(\mathrm{VO}_{4}\right)_{2} \cdot 3\left(\mathrm{H}_{2} \mathrm{O}\right)$ which has the weight percentage for elements K (8.67\%) V (11.29\%) U (59.86\%) [113] outlined in red in the PUzaf results. Sample was coated with Ir. The Ir peak is denoted by the *Ir and arrow. Ir coating was subtracted out before the normalization was performed by the program utilized by the instrument.

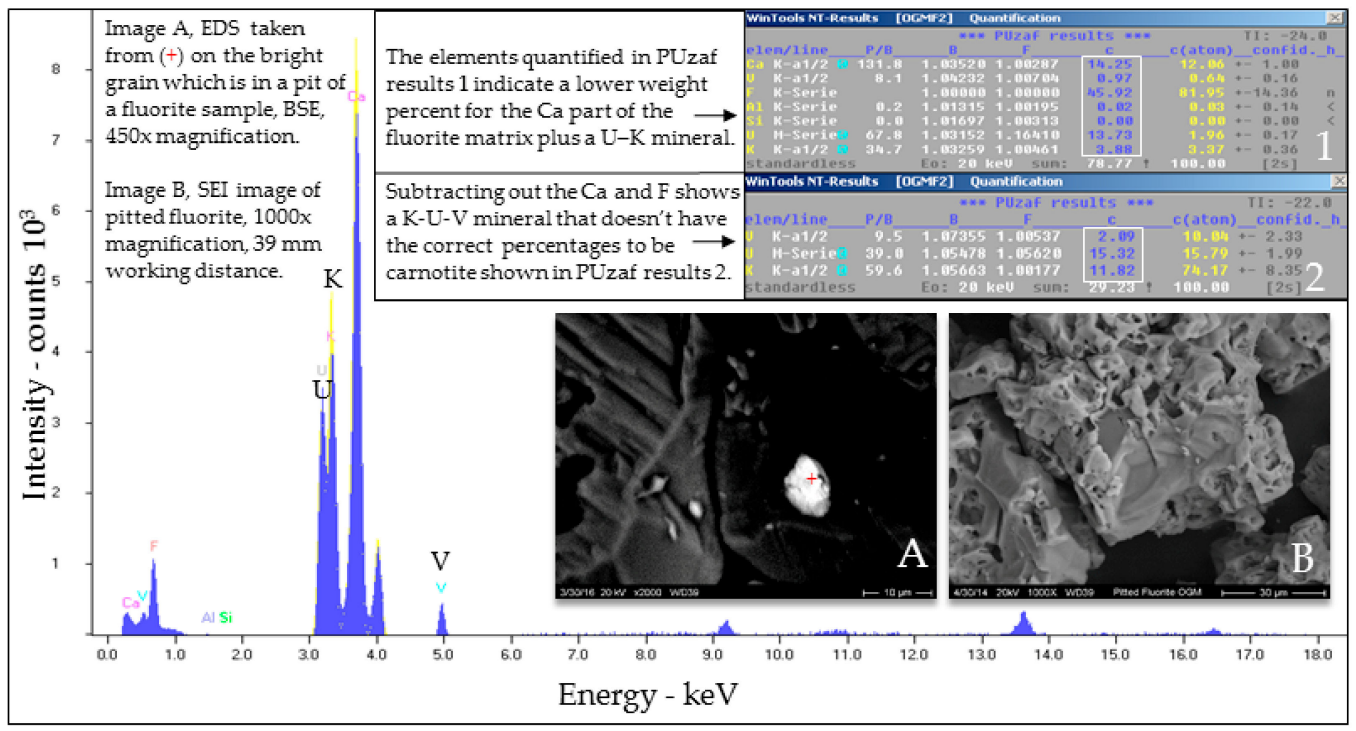

Figure A3. EDS spectrum for Old Glory mine fluorite sample with small grains of a K-U-V mineral. Spectrum taken from the bright grain in image A, BEI image, 2000× magnification. Pitted grains of fluorite pictured in the image B, from the Old Glory mine, SEI, 1000× magnification, 39 mm working distance. The presence of these $\mathrm{U}$ minerals in the fluorite sample likely account for the $\mathrm{U}$ and $\mathrm{V}$ concentration in the fluorite samples, Table A2, samples 28-32. 


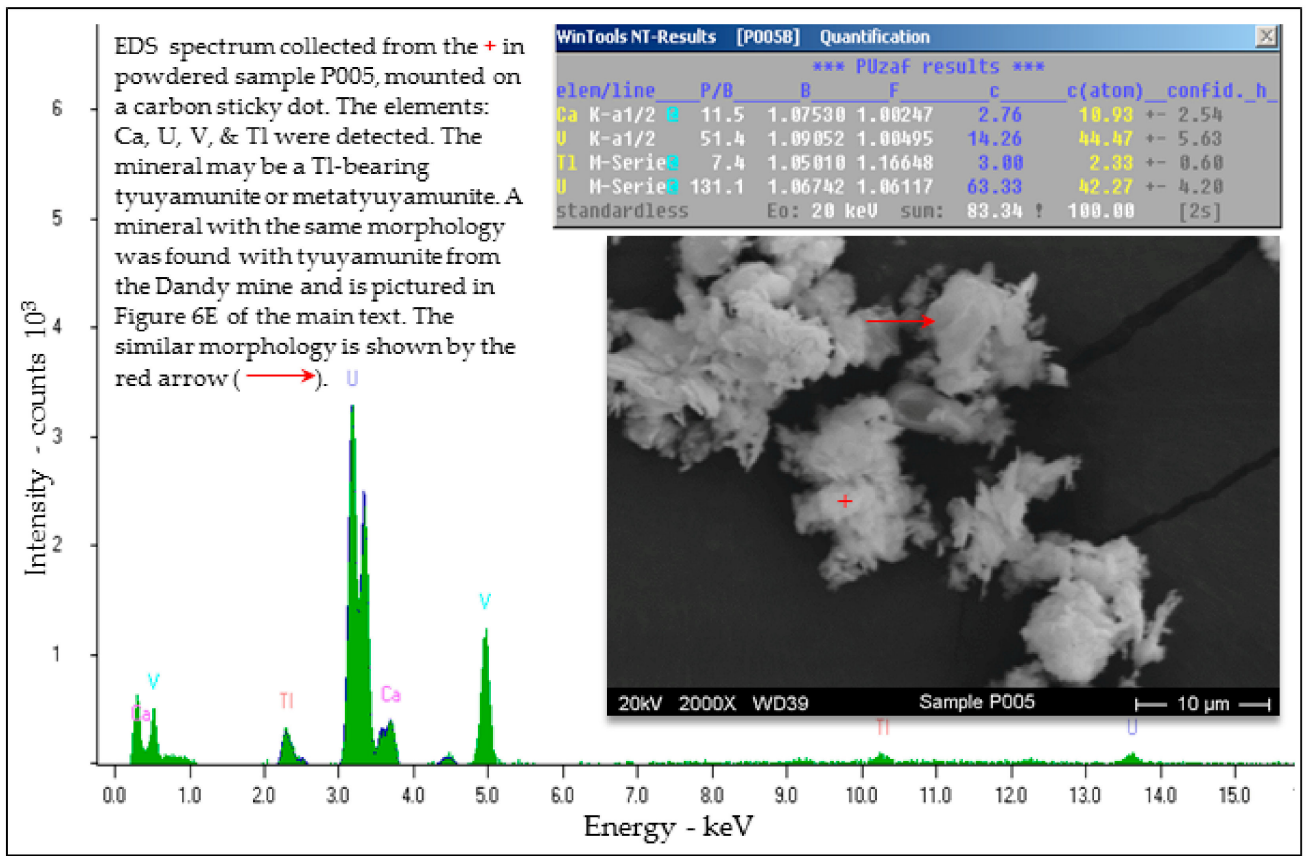

Figure A4. EDS spectrum for Tl-bearing uranyl vanadate from sample P005 collected from a U prospect in the PMD. The weight percent of the elements are similar to the carnotite group of metal-uranyl vanadates; the mineral may be a Tl-bearing variety. A mineral with the same morphology was found with tyuyamunite in a sample from the Dandy mine (Figure 9 main document). This sample had 340 ppm Tl (Table A1). Tl and Pb have similar atomic and covalent radii: $\mathrm{Tl}$ (1.70 ̊ and $1.47 \AA$ ) and $\mathrm{Pb}$ $(1.75 \AA$ and $1.46 \pm 5 \AA$ ).

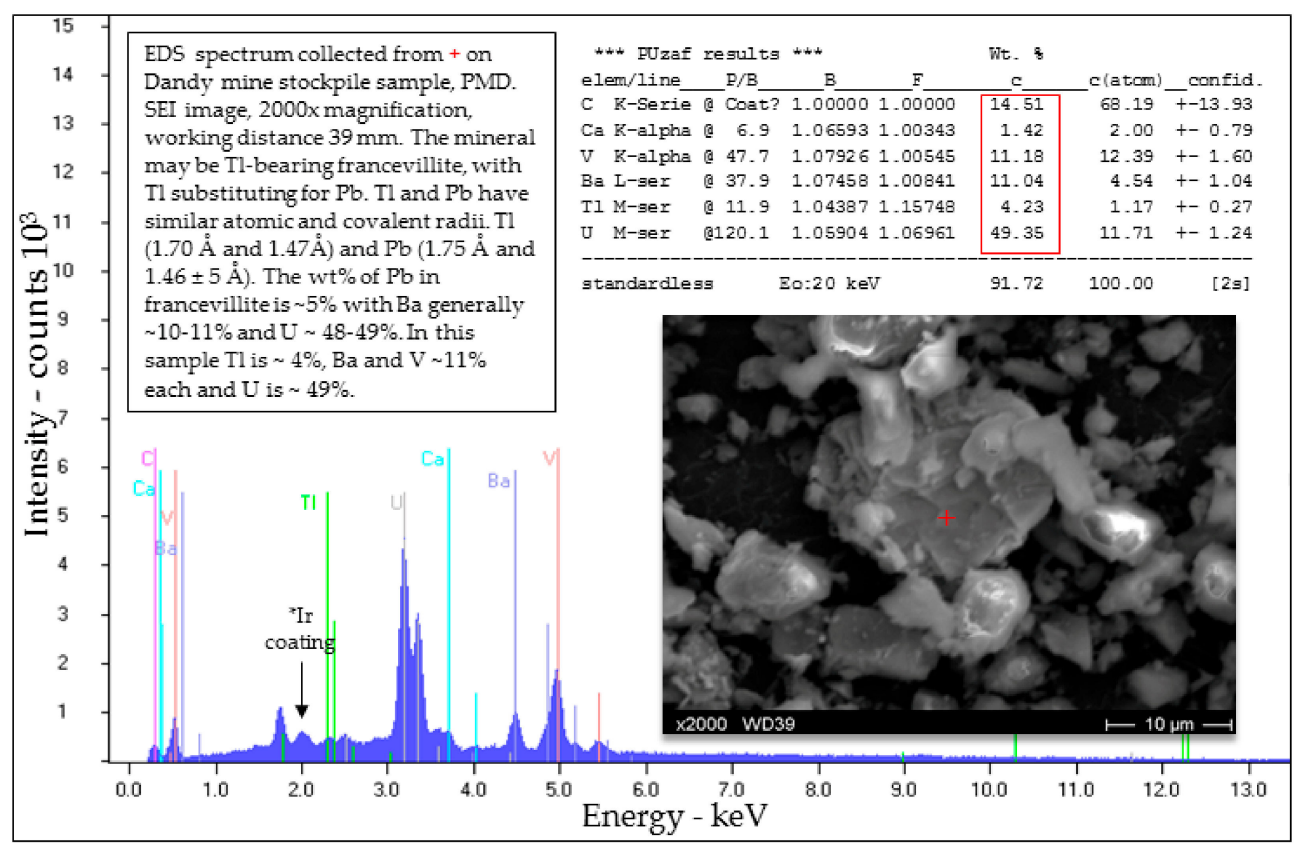

Figure A5. EDS spectrum for Tl-bearing uranyl vanadate from a sample collected from a stockpile area near the Dandy mine in the PMD. The weight percent of the elements are similar to francevillite which has an empirical formula $\mathrm{Ba}_{0.75} \mathrm{~Pb}_{0.25}\left(\mathrm{UO}_{2}\right)_{2} \mathrm{~V}^{5+}{ }_{2} \mathrm{O}_{8} \cdot 3\left(\mathrm{H}_{2} \mathrm{O}\right)$ with weight percentage for the elements $\mathrm{U}(48.64 \%) \mathrm{V}(10.41 \%) \mathrm{Ba}(10.52 \%) \mathrm{Pb}(5.29 \%)$ [114]. The sample may be a Tl-francevillite with $\mathrm{Tl}$ substituting for $\mathrm{Pb}$. Sample was coated with Ir. The Ir peak is denoted by the *Ir and arrow. Ir coating was subtracted out before the normalization was performed by the program utilized by the instrument. 


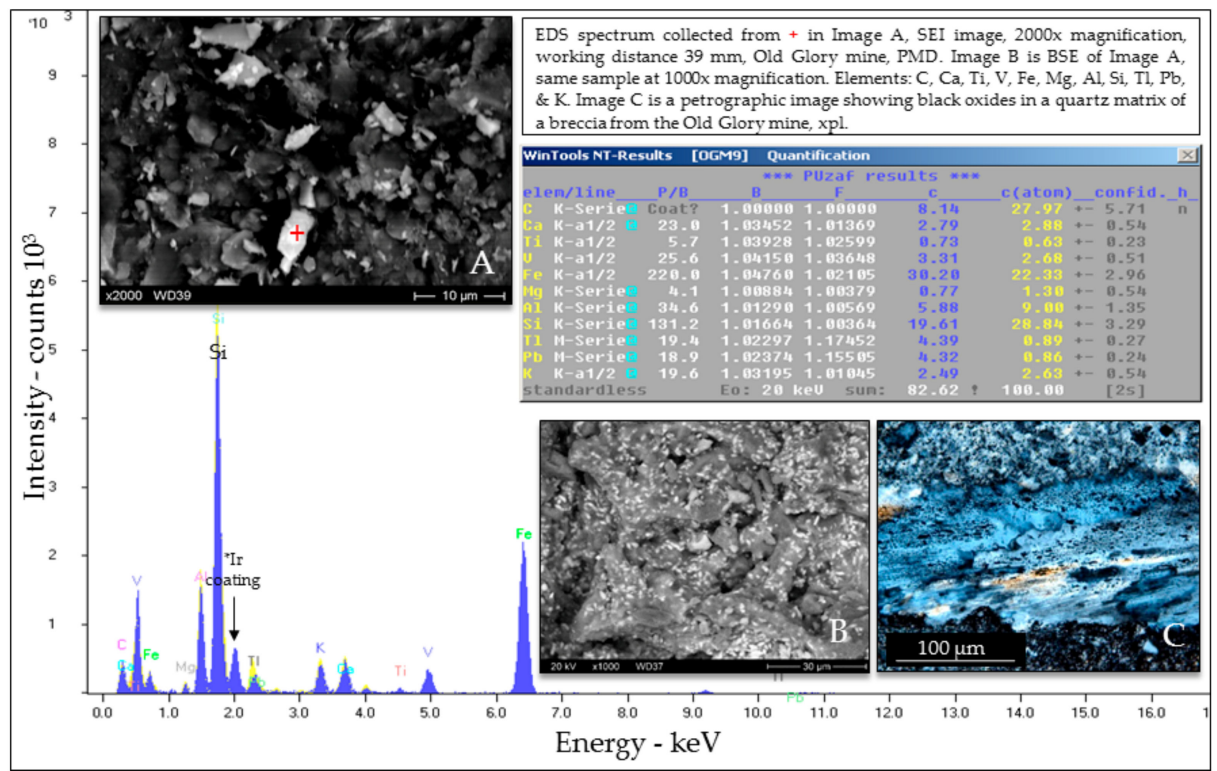

Figure A6. FeV oxides with $\mathrm{Tl}, \mathrm{Pb}$ and Ti from the Old Glory mine, PMD. The large Si peak is likely picked up by the Si matrix. Davidite, a U REE mineral in the Crichtonite Group, a group of about 13 complex metal titanates, identified by early workers using optical methods, was described as occurring in disseminations in and interstitial to a fluorite matrix $[5,14]$. Fe has the largest weight percent in the oxides of this sample. A much larger percentage of $\mathrm{Ti}$ would be needed to have a Crichtonite Group mineral, though these may occur locally in other samples. The FeV oxides show up well in image B, BSE, $1000 \times$ magnification. EDS collection site + is shown in image A, SEI 2000× magnification. Petrographic image $C$ shows inclusions of dark oxides in a quartz matrix and vein urefrom the Old Glory mine, PMD, xpl. Sample was coated with Ir. The Ir peak is denoted by the *Ir and arrow. Ir coating was subtracted out before the quantification was performed by the program utilized by the instrument.

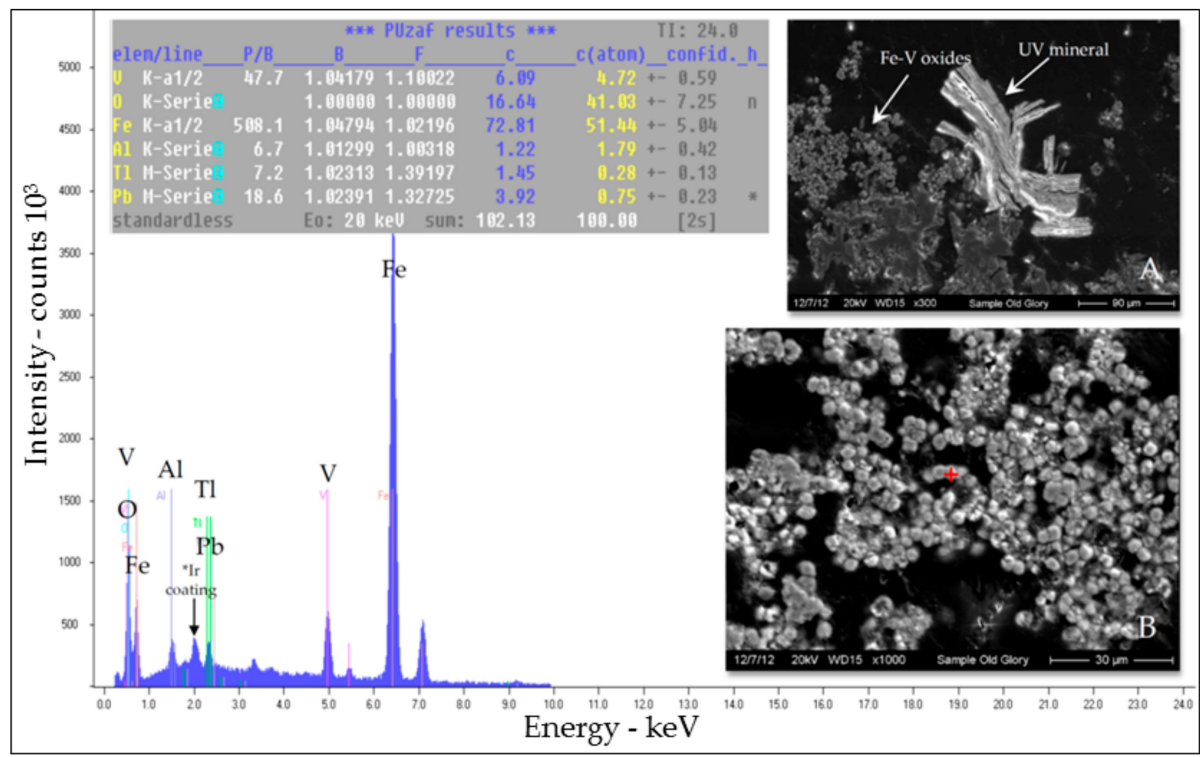

Figure A7. EDS spectrum collected from + from Fe-V oxides in sample from the Old Glory mine, PMD. The elements $\mathrm{V}, \mathrm{Fe}, \mathrm{Tl}, \mathrm{Pb}, \mathrm{Al}$ and $\mathrm{O}$ were detected. These oxides have a lighter colored rim indicating element(s) with larger $\mathrm{Z}$. The rims of the oxides may have the $\mathrm{Tl}$ and or $\mathrm{Pb}$. Sample was coated with Ir. The Ir peak is denoted by the *Ir and arrow. Ir coating was subtracted out before the quantification was performed by the program utilized by the instrument. 


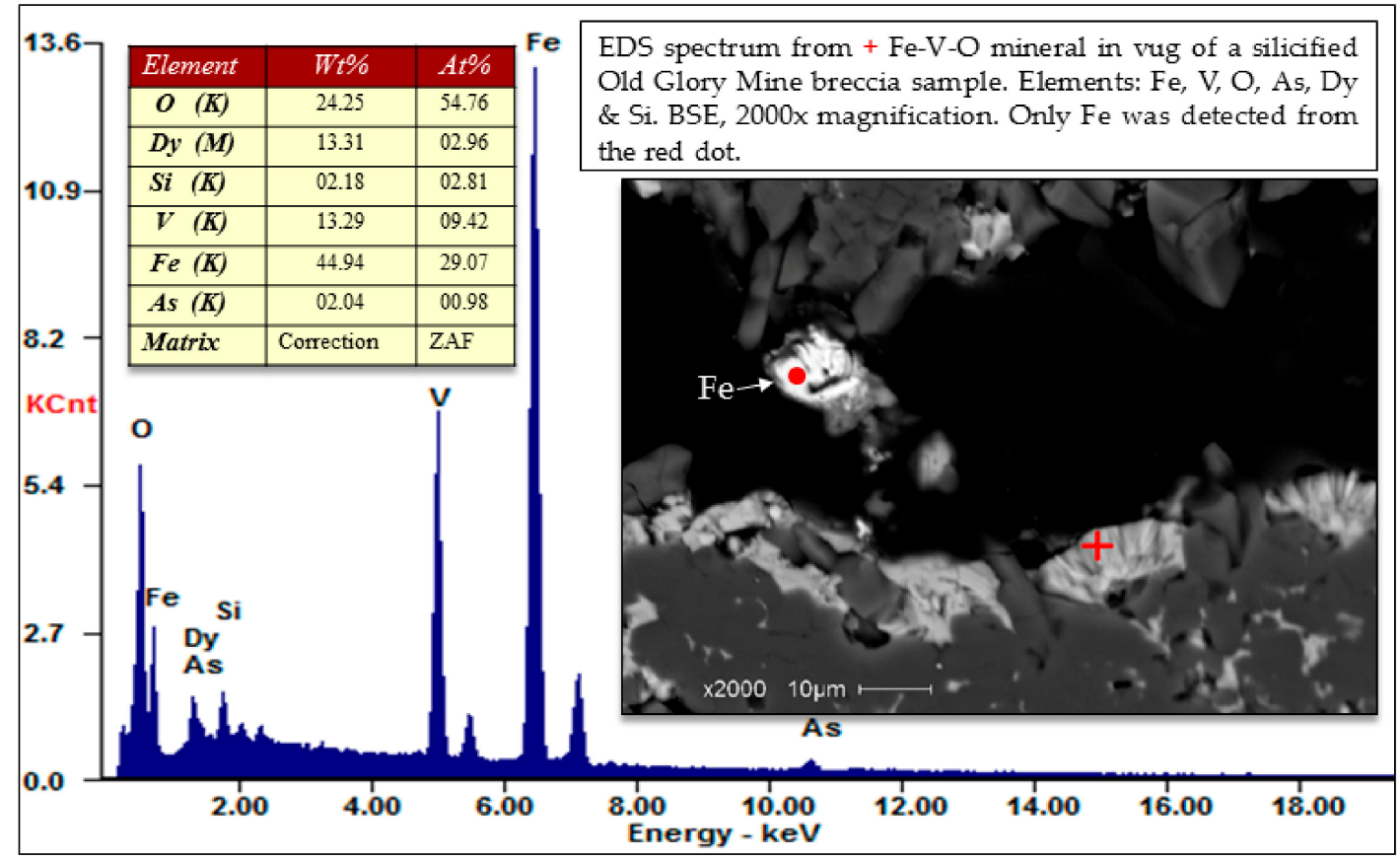

Figure A8. EDS spectrum collected from + in image above. As was determined by the peak at its characteristic $K_{a}$ energy of $10.53 \mathrm{keV}$ and Dy from the peak at $1.293 \mathrm{keV}$ where it partially overlaps with the As $\mathrm{L}_{\mathrm{a}}$ line. EDS analysis suggests that native iron is the phase located at the red dot; however, seems unlikely due to the associated minerals, and may be an artifact of thin section preparation. This work was performed at Montana Tech-CAMP by Gary Wyss.

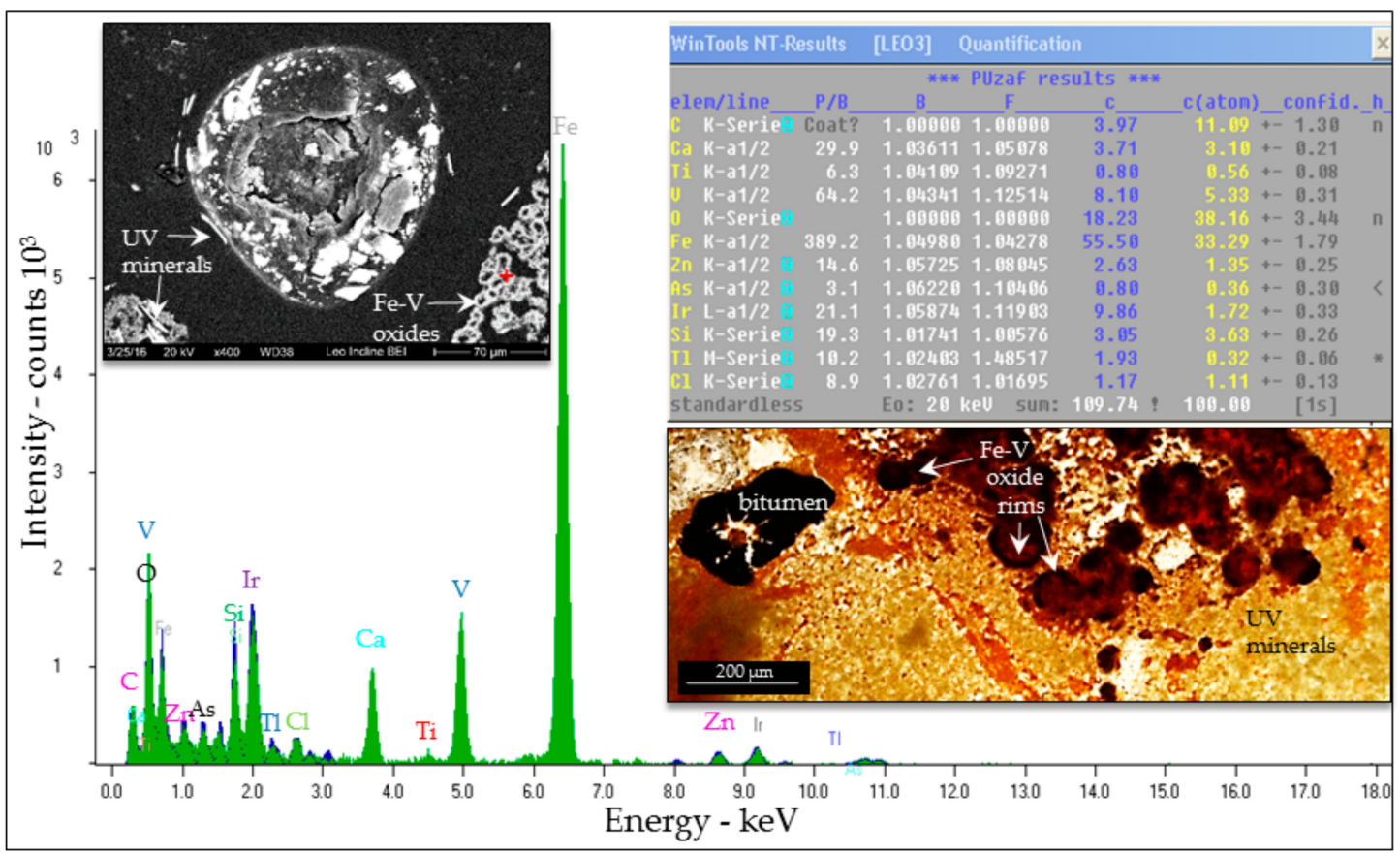

Figure A9. EDS spectrum collected from + in the BSE image above. Elements detected were C, Ca, Fe, $\mathrm{V}, \mathrm{Ti}, \mathrm{Zn}, \mathrm{As}, \mathrm{Tl}, \mathrm{Si}, \mathrm{Cl}$ and $\mathrm{O}$. The sample was coated with $\mathrm{Ir}$. $\mathrm{Cl}$ is likely from the epoxy for mounting the sample. Sample is a polished thin-section from a limestone breccia, Leo Incline area, LMD. The U-V minerals occur in close association with Fe-oxides and or hydroxides and bitumen. The black area in the image is an inclusion of bitumen. The red orange Fe-oxides, some with darker Fe-V rims show up well in plain polarized light as do the yellow to yellow green U-V minerals. 


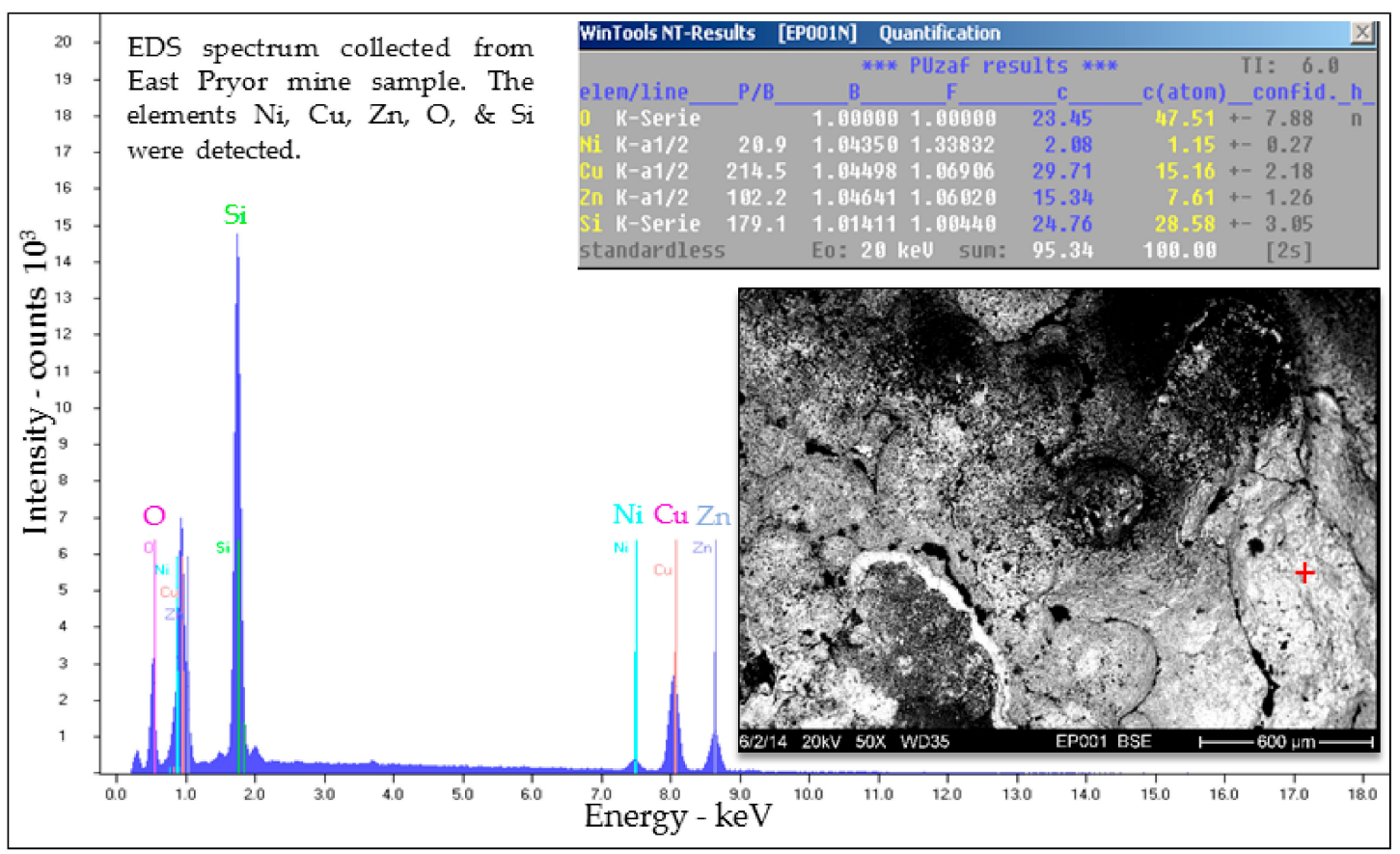

Figure A10. EDS spectrum collected from the red plus symbol + in the BSE image for unidentified mineral from the East Pryor mine, PMD, that did not have U. The elements $\mathrm{Zn}, \mathrm{Ni}, \mathrm{Cu}$, and $\mathrm{O}$ were detected. This mineral likely formed from the metals derived from hydrothermal fluids associated with Permian Phosphoria Formation sourced oil.

\section{References}

1. Montana's Clean Water Act Information Center (MCWAC). Available online: http:/ / deq.mt.gov/Water/ WQPB/cwaic/reports (accessed on 15 May 2017).

2. Barnhart, E. Differentiating natural vs. anthropogenic mercury inputs and subsequent $\mathrm{Se} / \mathrm{Hg}$ interactions and biogeochemical cycling in Bighorn Lake, Bighorn Canyon National Recreation Area, Montana and Wyoming. Presented at U.S. Geological Survey NOROCK EcoLunch and Webinar, Montana State University, Bozeman, MT, USA, 24 March 2016.

3. Eggers, M.J.; Moore-Nall, A.L.; Doyle, J.T.; Lefthand, M.J.; Young, S.L.; Bends, A.L.; Committee, C.E.H.S.; Camper, A.K. Potential Health Risks from Uranium in Home Well Water: An Investigation by the Apsaalooke (Crow) Tribal Research Group. Geosciences 2015, 5, 67-94. [CrossRef]

4. Cummins, C.; Eggers, M.; Hamner, S.; Camper, A.; Ford, T.E. Mercury levels detected in fish from rivers of the Crow Reservation, Montana. In Proceedings of the SCREES National Water Conference, St. Louis, MO, USA, 8-11 February 2009.

5. Van Gosen, B.S.; Wilson, A.B.; Hammarstrom, J.M. Mineral Resource Assessment of the Custer National Forest in the Pryor Mountains, Carbon County, South-Central Montana; U.S. Geological Survey Open-File Report 96-256; U.S. Geological Survey: Denver, CO, USA, 1996; 76p. Available online: https:/ / pubs.er.usgs.gov/ publication/ofr96256 (accessed on 13 December 2015).

6. Patterson, C.G.; Toth, M.I.; Kulik, D.M.; Esparza, L.E.; Schmauch, S.W.; Benham, J.R. Mineral Resources of the Pryor Mountain, Burnt Timber Canyon, and Big Horn Tack-on Wilderness Study Areas, Carbon County, Montana and Big Horn County, Wyoming; U.S. Geological Survey Bulletin 1723; U.S. Geological Survey: Denver, CO, USA, 1988; pp. 1-15. Available online: https:/ / pubs.er.usgs.gov/publication/b1723 (accessed on 13 December 2015).

7. Hauptman, C.M. Uranium in the Pryor Mountain area of southern Montana and northern Wyoming. Uranium Mod. Min. 1956, 3, 14-21.

8. Hart, O.M. Uranium deposits in the Pryor-Big Horn Mountains, Carbon County, Montana, and Big Horn County, Wyoming. In Proceedings of the United Nations 2nd International Conference on Peaceful Uses of Atomic Energy, Geneva, Switzerland, 1-13 September 1958; pp. 523-526. 
9. Harris, R.E. Uranium and thorium in the Bighorn Basin. In Wyoming Geological Association, 34th Annual Field Conference Guidebook, 1983, Geology of the Bighorn Basin; Boberg, W.W., Ed.; Wyoming Geological Association: Casper, WY, USA, 1983; pp. 171-177. ISBN 9789993362418.

10. Hurley, G. Geology and Mineralogy of the Devil Canyon/Little Mountain Area, Northern Big Horn Mountains, Wyoming. In Wyoming Geological Association, 47th Annual Field Conference Guidebook, 1996, Resources of the Bighorn Basin; Bowen, C.E., Kirkwood, S.C., Miller, T.S., Eds.; Wyoming Geological Association: Casper, WY, USA, 1996; pp. 281-295.

11. McEldowney, R.C.; Abshier, J.F.; Lootens, D.J. Geology of uranium deposits in the Madison Limestone, Little Mountain area, Big Horn County, Wyoming. In Exploration frontiers of the Central and Southern Rockies; Veal, H.K., Ed.; Rocky Mountain Association of Geologists: Denver, CO, USA, 1977; pp. 321-336.

12. Wilson, W.H. Radioactive Mineral Deposits of Wyoming Geological Survey of Wyoming; Report of Investigations; Wyoming Geologic Survey: Laramie, WY, USA, 1960; Volume 7, 41p.

13. Abandoned Mine Lands Portal. Available online: http://www.abandonedmines.gov/wbd_um.html (accessed on 20 December 2014).

14. Warchola, R.J.; Stockton, T.J. National Uranium Resource Evaluation, Billings Quadrangle, Montana; Technical Report PGJ/F-015(82); U.S. Department of Energy: Grand Junction, CO, USA, 1982; 33p.

15. Sahinen, U.M. Fluorspar deposits in Montana. MBMG Bull. 1962, 28, 34-35.

16. U.S. Department of Energy. Billings Quadrangle-Residual Intensity Magnetic Anomaly Contour Map; Open-File Report GJM-096, pl.4; U.S. Department of Energy: Grand Junction, CO, USA, 1982.

17. Schultz, R.L. Caves of the Bighorn-Pryor Mountains of Montana and Wyoming. JCKS 1969, 10, 1-28.

18. Engel, A.S.; Stern, L.A.; Bennett, P.C. Microbial contributions to cave formation: New insight into sulfuric acid speleogenesis. Geology 2004, 32, 369-372. [CrossRef]

19. Egemeier, S.J. Cavern Development by Thermal Waters with a Possible Bearing on Ore Deposition. Ph.D. Thesis, Stanford University, Stanford, CA, USA, 1973.

20. Love, J.D. Vanadium and Associated Elements in the Phosphoria Formation in the Afton Area, Western Wyoming; U.S. Geological Survey Professional Paper 424C; U.S. Geological Survey: Denver, CO, USA, 1961; pp. C279-C282.

21. Love, J.D.; Smith, D.G.; Browne, D.G.; Carter, L.M. Vanadium Deposits in the Lower Permian Phosphoria Formation, Afton Area, Lincoln County, Western Wyoming; U.S. Geological Survey Professional Paper 1637; U.S. Geological Survey: Denver, CO, USA, 2004; 28p, ISBN 9780607916898.

22. Rubey, W.W. Vanadiferous shale in the Phosphoria Formation, Wyoming and Idaho. (Abstract). Econ. Geol. 1943, 38, 87 .

23. Stone, D.S. Theory of Paleozoic Oil and Gas Accumulation Bighorn Basin Wyoming. AAPG Bull. 1967, 51, 2056-2114.

24. Sheldon, R.P. Long distance migration of oil in Wyoming. Mt. Geol. 1967, 4, 53-65.

25. Blackstone, D.L., Jr. Foreland deformation, compression as a cause. Rocky Mt. Geol. 1980, 18, 83-100.

26. Blackstone, D.L., Jr. Foreland Compressional Tectonics: Southern Bighorn Basin and Adjacent Areas, Wyoming; Geological Survey of Wyoming Report of Investigations; Wyoming Geological Survey: Laramie, WY, USA, 1986; Volume 34, pp. 1-27.

27. Richards, P.W. Geology of the Bighorn Canyon-Hardin Area, Montana and Wyoming; U.S. Geological Survey Bulletin 1026; USGS: Helena, MT, USA, 1955; pp. 1-93. Available online: http:/ / pubs.usgs.gov/bul/1026/ report.pdf (accessed on 13 December 2015).

28. Sando, W.J. Madison Limestone (Mississippian) paleokarst: A geologic synthesis. In Paleokarst; James, N.P., Choquette, P.W., Eds.; Springer: New York, NY, USA, 1988; pp. 256-277.

29. Sando, W.J. Ancient solution phenomena in the Madison Limestone (Mississippian) of north-central Wyoming. USGS J. Res. 1974, 2, 133-141.

30. Lopez, D.A. Field Guide to the Northern Pryor Bighorn Structural Block, South Central Montana; Open-File Report 330; Montana Bureau of Mines and Geology: Butte, MT, USA, 1995.

31. Bird, P. Stress direction history of the western United States and Mexico since 85 Ma. Tectonics 2002, 21, 1-12. [CrossRef]

32. Neely, T.G.; Erslev, E.A. The interplay of fold mechanisms and basement weaknesses at the transition between Laramide basement-involved arches, north-central Wyoming, USA. J. Struct. Geol. 2009, 31, 1012-1027. [CrossRef] 
33. Brown, W.G. Structural style of Laramide basement-cored uplifts and associated folds. In Geology of Wyoming; Snoke, A., Steidtmann, J., Roberts, S., Eds.; Geological Survey of Wyoming Memoir No. 5; The Geological Survey of Wyoming: Laramie, WY, USA, 1993; pp. 312-371.

34. Dickinson, W.R.; Klute, M.A.; Hayes, M.J.; Janecke, S.U.; Lundin, E.R.; McKittrick, M.A.; Olivares, M.D. Paleogeographic and paleotectonic setting of Laramide sedimentary basins in the central Rocky Mountain region. Geol. Soc. Am. Bull. 1988, 100, 1023-1039. [CrossRef]

35. Erslev, E.A. Thrusts, back-thrusts, and detachment of the Rocky Mountain foreland arches. In Laramide Basement Deformation in the Rocky Mountain Foreland of the Western United States; Schmidt, C.J., Chase, R.B., Erslev, E.A., Eds.; Geological Society of America Special Papers 280: Boulder, Colorado, USA, 1993; pp. 339-358.

36. Stahl, J. Fracture Analysis of Circum-Bighorn Basin Anticlines, Wyoming-Montana. Master's Thesis, Montana State University, Bozeman, MT, USA, 2015.

37. Moore-Nall, A.L.; Lageson, D.R. Uranium Vanadium Mineralization in Mississippian Aged Paleokarst, Northern Bighorn Basin, Montana and Wyoming, Indicates a Hydrothermal Permian Phosphoria Formation Source of Metals Including REE and Tl. Presented at the the GSA Annual Meeting, Denver, Colorado, USA, 9-12 October 2016; Available online: https:/ / gsa.confex.com/gsa/2016AM/webprogram/Paper287959.html (accessed on 13 December 2016).

38. Dickson, J.A.D. A modified technique for carbonates in thin section. Nature 1965, 205, 587. [CrossRef]

39. Folk, R.L. Detection of organic matter in thin sections of carbonate rock using a white card. Sediment. Geol. 1987, 54, 193-200. [CrossRef]

40. Serc.Carleton Website. Available online: http://serc.carleton.edu/research_education/geochemsheets/bse. html (accessed on 17 November 2015).

41. Moore-Nall, A.L.; Lageson, D.R. Francevillite $\left[(\mathrm{Ba}, \mathrm{Pb})\left(\mathrm{UO}_{2}\right)_{2}\left(\mathrm{~V}_{2} \mathrm{O}_{8}\right) \cdot 5 \mathrm{H}_{2} \mathrm{O}\right]$ identified in the Uranium Vanadium deposits in the Pryor Mountain Mining District, Montana and the Little Mountain Mining District, Wyoming may provide a link to the elevated lead in the Bighorn River and be related to fluid migration of the Lower Kane Cave, Wyoming. Presented at the GSA Annual Meeting, Denver, CO, USA, 27-30 October 2013; Available online: https://gsa.confex.com/gsa/2013AM/webprogram/Paper225217.html (accessed on 10 December 2015).

42. Francevillite. Available online: http://www.handbookofmineralogy.org/pdfs/francevillite.pdf (accessed on 21 December 2015).

43. Carnotite Group. Available online: http://www.mindat.org/min-32551.html (accessed on 21 December 2015).

44. Thallian Carnotite. Available online: http://www.mindat.org/min-32379.html (accessed on 21 December 2015).

45. Burns, P.C.; Finch, R. (Eds.) Reviews in Mineralogy, Uranium: Mineralogy, Geochemistry and the Environment; Mineralogical Society of America: Washington, DC, USA, 1999; Volume 38, 680p.

46. Davies, G.R.; Smith, L.B., Jr. Structurally controlled hydrothermal dolomite reservoir facies: An Overview. AAPG Bull. 2006, 90, 1641-1690. [CrossRef]

47. Katz, D.A.; Eberli, G.P.; Swart, P.K.; Smith, L.B. Tectonic-hydrothermal brecciation associated with calcite precipitation and permeability destruction in Mississippian carbonate reservoirs Montana and Wyoming. AAPG Bull. 2006, 90, 1803-1841. [CrossRef]

48. Smith, L.B., Jr.; Eberli, G.P.; Sonnenfeld, M.D. Sequence stratigraphic and paleogeographic distribution of reservoir quality dolomite, Madison Formation, Wyoming and Montana. In Integration of Outcrop and Modern Analogues in Reservoir Modeling; AAPG Memoir; Grammer, G.M., Eberli, G.P., Harris, P.M., Eds.; American Association of Petroleum Geologists: Tulsa, OK, USA, 2004; Volume 80, pp. 94-118.

49. Westphal, H.; Eberli, G.P.; Smith, L.B.; Grammer, G.M.; Kislak, J. Reservoir characterization of the Mississippian Madison Formation, Wind River Basin, Wyoming. AAPG Bull. 2004, 88, 405-432. [CrossRef]

50. Kislak, J.; Smith, L.; Peacock, D.; Eberli, G.; Swart, P. Classification, Distribution and Origin of Hydrothermal Breccias, Madison Formation, Wyoming. In Proceedings of the AAPG Annual Meeting Program; American Association of Petroleum Geologists: Denver, CO, USA, 2001.

51. Beaudoin, N.; Bellahsen, N.; Lacombe, O.; Emmanuel, L. Fracture-controlled paleohydrogeology in a basement-cored, fault-related fold: Sheep Mountain Anticline, Wyoming, United States. Geochem. Geophys. Geosyst. 2011, 12, 1-15. [CrossRef] 
52. Spötl, C.; Pitman, J.K. Saddle (Baroque) Dolomite in Carbonates and Sandstones: A Reappraisal of a Burial-Diagenetic Concept. In Carbonate Cementation in Sandstones: Distribution Patterns and Geochemical Evolution; Morad, S., Ed.; Blackwell Publishing Ltd.: Oxford, UK, 1998; Chapter 19.

53. Moore-Nall, A.L.; Lageson, D.R. Herkimer diamonds in the Pennsylvanian Tensleep Formation may indicate hydrothermal influences for mineralization of the Red Pryor Mountain uranium/vanadium deposits. Presented at the GSA Annual Meeting, Minneapolis, MN, USA, 9-12 October 2011; Available online: https:/ /gsa.confex.com/gsa/2011AM/ finalprogram/abstract_198138.htm (accessed on 10 December 2015).

54. Witherite. Available online: http:/ / www.mindat.org/min-4299.html (accessed on 17 February 2016).

55. Halloysite. Available online: http://www.mindat.org/min-1808.html (accessed on 17 February 2016).

56. Mariano, A.N. Some further geological applications of cathodoluminescence. In Cathodoluminescence of Geological Materials; Marshall, D.J., Ed.; Unwin Hyman: Boston, MA, USA, 1988; 146p.

57. Cherniak, D.J.; Zhang, X.Y.; Wayne, N.K.; Watson, E.B. Sr, Y, and REE diffusion in fluorite. Chem. Geol. 2001, 181, 99-111. [CrossRef]

58. Marshall, D.J. Cathodoluminescence of Geological Materials; Unwin Hyman: Boston, MA, USA, 1988; 146p.

59. Habermann, D.; Neuser, R.D.; Richter, D.K. REE-activated cathodoluminescence of calcite and dolomite: High-resolution spectrometric analysis of CL emission (HRS-CL). Sediment. Geol. 1996, 101, 1-7. [CrossRef]

60. Summa, L.; Senior Technical Consultant, ExxonMobile Upstream Research Company, Houston, TX, USA Results of fluid inclusion work from Pryor Mountains performed at Fluid Inc., Denver, CO, USA. Personal communication, 6 December 2011.

61. Reynolds, J.A.; Scientist, Fluid Inc., Denver, CO, USA Description of Fluid Inclusion Work of Pryor Mountain Samples at Fluid Inc. Personal communication, 2 December 2011.

62. Gromet, P.L.; Dymek, R.F.; Haskin, L.A.; Korotev, R.L. The "North American shale composite"—Its compilation, major and trace element characteristics. Geochim. Cosmochim. Acta 1984, 48, 2469-2482. [CrossRef]

63. Taylor, S.R.; McLennan, S.M. Rare Earth Elements in Sedimentary Rocks: Influence of Provenance and Sedimentary Processes. In Geochemistry and Mineralogy of Rare Earth Elements; Lipin, R.R., McKay, G.A., Eds.; Mineralogical Society of America: Washington, DC, USA, 1989; Volume 21, pp. 169-200.

64. McKelvey, V.E.; Williams, J.S.; Sheldon, R.P.; Cressman, E.R.; Cheney, T.M.; Swanson, R.W. The Phosphoria, Park City, and Shedhorn Formations in the Western Phosphate Field; U.S. Geological Survey Professional Paper 313-A; U.S. Geological Survey: Denver, CO, USA, 1959; 47p.

65. Sheldon, R.P. Physical Stratigraphy and Mineral Resources of Permian Rocks in Western Wyoming; U.S. Geological Survey, Professional Paper 313-B; U.S. Geological Survey: Denver, CO, USA, 1963; 273p.

66. Gulbrandsen, R.A.; Reeser, D.W. An occurrence of Permian manganese nodules near Dillon, Montana; U.S. Geological Survey Professional Paper 650-C; U.S. Geological Survey: Denver, CO, USA, 1969; pp. C49-C57.

67. Gulbrandsen, R.A. Analytical Data on the Phosphoria Formation Western United States; U.S. Geological Survey Open-File Report 75-554; U.S. Geological Survey: Washington, DC, USA, 1975; 45p. Available online: http:/ / pubs.usgs.gov/of/1975/0554/report.pdf (accessed on 17 February 2016).

68. McKelvey, V.E.; Strobell, J.D., Jr.; Slaughter, A.L. The Vanadiferous Zone of the Phosphoria Formation in Western Wyoming and Southeastern Idaho; U.S. Geological Survey, Professional Paper 1465; U.S. Geological Survey: Denver, CO, USA, 1986; 27p.

69. Medrano, M.D.; Piper, D.Z. Partition of Minor Elements and Major-Element Oxides between Rock Components and Calculation of the Marine-Derived Fraction of the Minor Elements in Rocks of the Phosphoria Formation, Idaho and Wyoming; U.S. Geological Survey Open-File Report 95-270; U.S. Geological Survey: Denver, CO, USA, 1995; 79p.

70. Piper, D.Z. Trace Elements and Major-Element Oxides in the Phosphoria Formation at Enoch Valley, Idaho; Permian Sources and Current Reactivity; U.S. Geological Survey Open File Report 99-0163; U.S. Geological Survey: Denver, CO, USA, 1999; 66p. Available online: https:/ / pubs.er.usgs.gov/publication/ofr99163 (accessed on 17 February 2016).

71. Piper, D.Z.; Skorupa, J.P.; Presser, T.S.; Hardy, M.A.; Hamilton, S.J.; Huebner, M.; Gulbrandsen, R.A. The Phosphoria Formation at the Hot Springs Mine in Southeast Idaho: A Source of Selenium and other Trace Elements to Surface Water, Ground Water, Vegetation, and Biota; U.S. Geological Survey Open-File Report 00-050; U.S. Geological Survey: Denver, CO, USA, 2000; 73p. 
72. Moyle, P.R.; Causey, D.J. Chemical Composition of Samples Collected from Waste Rock Dumps and Other Mining-Related Features at Selected Phosphate Mines in Southeastern Idaho, Western Wyoming, and Northern Utah; U.S. Geological Survey Open-File Report 01-411; U.S. Geological Survey: Denver, CO, USA, 2001; 46p.

73. Hein, J.R.; McIntyre, B.; Perkins, R.B.; Piper, D.Z.; Evans, J. Composition of the Rex Chert and Associated Rocks of the Permian Phosphoria Formation: Soda Springs Area, SE Idaho; U.S. Geological Survey Open File Report 02-345; U.S. Geological Survey: Denver, CO, USA, 2002; 30p.

74. Perkins, R.B.; McIntyre, B.; Hein, J.R.; Piper, D.Z. Geochemistry of Permian rocks from the Margins of the Phosphoria Basin: Lakeridge Core, Western Wyoming; U.S. Geological Survey Open File Report 03-21; U.S. Geological Survey: Denver, CO, USA, 2003; 60p.

75. Emsbo, P.; McLaughlin, P.I.; Breit, G.N.; Du Bray, E.A.; Koenig, A.E. Rare earth elements in sedimentary phosphate deposits: Solution to the global REE crisis? Gondwana Res. 2015, 27, 776-785. Available online: http: / / www.sciencedirect.com/science/article/pii/S1342937X14003128 (accessed on 27 March 2016). [CrossRef]

76. Jasinski, S.M. Phosphate Rock; U.S. Geological Survey Mineral Commodity Summaries; U.S. Geological Survey: Denver, CO, USA, 2011; pp. 118-119.

77. Carnes, J.D. Phosphate Rock in Wyoming; Wyoming State Geological Survey Report of Investigations No. 68; U.S. Geological Survey: Denver, CO, USA, 2015; 34p.

78. Goldberg, E.D. Chemistry in the Oceans. In Oceanography; Sears, M., Ed.; American Association for the Advancement of Science: Washington, DC, USA, 1961; Volume 67, pp. 583-597.

79. Elderfield, H.; Greaves, M. The rare earth elements in seawater. Nature 1982, 296, 214-219. [CrossRef]

80. Sholkovitz, E.R. Ocean particle chemistry: The fractionation of rare earth elements between suspended particles and seawater. Geochim. Cosmochim. Acta 1994, 58, 1567-1579. [CrossRef]

81. Lillis, P.G.; Selby, D. Evaluation of the rhenium-osmium geochronometer in the Phosphoria petroleum system, Bighorn Basin of Wyoming and Montana, USA. Geochim. Cosmochim. Acta 2013, 118, 312-330. [CrossRef]

82. Wyoming State Geological Survey Website, Oil and Gas Map. Available online: http:/ /www.wsgs.wyo.gov / products/wsgs-2016-ms-103.pdf (accessed on 8 October 2016).

83. Meyer, R.F.; Attanasi, E.D.; Freeman, P.A. Heavy Oil and Natural Bitumen Resources in Geological Basins of the World; U.S. Geological Survey Open-File Report 2007-1084; U.S. Geological Survey: Denver, CO, USA, 2007. Available online: http:/ / pubs.usgs.gov/of/2007/1084/ (accessed on 10 October 2016).

84. Hollerbach, A. Influence of Biodegradation on the Chemical Composition of Heavy Oil and Bitumen: Characterization, Maturation, and Degradation. In Exploration for Heavy Crude Oil and Natural Bitumen; Section II; Meyer, R.F., Ed.; AAPG Studies in Geology: Tulsa, OK, USA, 1997; pp. 243-247.

85. Langmuir, D. Uranium solution-mineral equilibria at low temperatures with applications to sedimentary ore deposits. Geochim. Cosmochim. Acta 1978, 42, 547-569. [CrossRef]

86. Finch, R.; Murakami, T. Systematics and Paragenesis of Uranium Minerals. In Reviews in Mineralogy, Uranium: Mineralogy, Geochemistry and the Environment; Burns, P.C., Finch, R., Eds.; Mineralogical Society of America: Washington, DC, USA, 1999; Volume 38, pp. 91-179.

87. Garrels, R.M.; Christ, C.L. Behavior of uranium minerals during oxidation. In Geochemistry and Mineralogy of the Colorado Plateau Uranium Ores; U.S. Geological Survey Professional Paper 320; Garrels, R.M., Larsen, E.S., Eds.; U.S. Geological Survey: Washington, DC, USA, 1959; pp. 81-90.

88. Phillips, W.J. Hydraulic fracturing and mineralization. J. Geol. Soc. 1972, 128, 337-359. [CrossRef]

89. Sibson, R.H.; Moore, J.M.M.; Rankin, A.H. Seismic pumping-A hydrothermal fluid transport mechanism. J. Geol. Soc. Lond. 1975, 131, 653-659. [CrossRef]

90. Du Bray, E.A.; Harlan, S.S. Geology and Tectonic Setting of the Cretaceous Sliderock Mountain volcano, Montana; U.S. Geological Survey Professional Paper 1602; U.S. Geological Survey: Denver, CO, USA, 1998; 19p. Available online: http:/ / pubs.er.usgs.gov/publication/pp1602 (accessed on 10 December 2015).

91. Brozdowski, R.A. Geologic Setting and Xenoliths of the Lodgepole Intrusive Area-Implications for the Northern Extent of the Stillwater Complex. Ph.D. Thesis, Temple University, Philadelphia, PA, USA, 1983.

92. Stock, G.M.; Riihimaki, C.A.; Anderson, R.S. Age constraints on cave development and landscape evolution in the Bighorn Basin of Wyoming, USA. J. Cave Karst Stud. 2006, 68, 76-84.

93. Sadeghi, S.; Sheikhzadeh, E. Solid phase extraction using silica gel modified with murexide for preconcentration of uranium (VI) ions from water samples. J. Hazard. Mater. 2009, 163, 861-868. [CrossRef] [PubMed] 
94. Allen, J.; Berlin, M.; Hughes, M.; Johnston, E.; Kailasam, V.; Rosenberg, E.; Sardot, T.; Wood, J.; Hart, C. Structural design at the polymer surface interface in nanoporous silica polyamine composites. Mater. Chem. Phys. 2011, 126, 973-982. [CrossRef]

95. Rosenberg, E.; Pang, D. System for Extracting Soluble Heavy Metals from Liquid Solutions: Assigned to UM, licensed to Purity Systems, Inc. U.S. Patent No. 5,997,748, 1999.

96. System for Extracting Soluble Heavy Metals from Liquid Solutions: With David Pang, assigned to UM, licensed to Purity Systems, Inc. U.S. Patent 5,695,882, 1997.

97. Allen, J.J.; Rosenberg, E.; Johnston, E.; Hart, C. Sol-gel synthesis and characterization of silica polyamine composites: Applications to metal ion capture. ACS Appl. Mater. Interfaces 2012, 4, 1573-1584. [CrossRef] [PubMed]

98. Hughes, M.A.; Nielsen, D.; Rosenberg, E.; Gobetto, R.; Viale, A.; Burton, S.D.; Ferel, J. Structural investigations of silica polyamine composites: Surface coverage, metal ion coordination, and ligand modification. Ind. Eng. Chem. Res. 2006, 45, 6538-6547. [CrossRef]

99. Kailasam, V.; Rosenberg, E.; Nielsen, D. Characterization of surface-bound Zr(IV) and its application to removal of $\mathrm{As}(\mathrm{V})$ and $\mathrm{As}(\mathrm{III})$ from aqueous systems using phosphonic acid modified nanoporous silica polyamine composites. Ind. Eng. Chem. Res. 2009, 48, 3991-4001. [CrossRef]

100. Hughes, M.A.; Rosenberg, E. Characterization and applications of poly-acetate modified silica polyamine composites. Sep. Sci. Technol. 2007, 42, 261-283. [CrossRef]

101. Kailasam, V. The Removal and Recovery of Oxo-Anions from Aqueous Systems Using Nano-Porous Silica Polyamine Composites. Ph.D. Thesis, University of Montana, Missoula, MT, USA, 2009.

102. Hughes, M.; Miranda, P.; Nielsen, D.; Edward Rosenberg, E.; Gobetto, R.; Alessandra Viale, A.; Burton, S. Silica polyamine composites: New supramolecular materials for cation and anion recovery and remediation. Macromol. Symp. 2006, 235, 161-178. [CrossRef]

103. Taylor, S.R.; McLennan, S.M. The Continental Crust: Its Composition and Evolution; Blackwell Scientific Publishing: Oxford, UK, 1985; p. 312.

104. Mulkey, J.P.; Oehme, F.W. A review of thallium toxicity. Vet. Hum. Toxicol. 1993, 35, 445-453. [PubMed]

105. Thallium Element Information. Available online: http://www.rsc.org/periodic-table/element/81/thallium (accessed on 17 February 2016).

106. Ikramuddin, M.; Asmeron, Y.; Nordstrom, P.M.; Kinart, K.P.; Martin, W.M.; Digby, S.J.M.; Elder, D.D.; Nijak, W.F.; Afemari, A.A. Thallium: A potential guide to mineral deposits. J. Geochem. Explor. 1983, 19, 465-490. [CrossRef]

107. De Albuquerque, C.A.R.; Shaw, D.M. Thallium. In Handbook of Geochemistry; Wedepohl, K.H., Ed.; Springer: Berlin, Germany, 1972; Volume 2, Section 81.

108. Berger, B.R. Descriptive model of carbonate-hosted Au-Ag. In Mineral Deposit Models; Cox, D.P., Singer, D.A., Eds.; U.S. Geological Survey Bulletin 1693; U.S. Geological Survey: Denver, CO, USA, 1986; p. 175.

109. Berger, B.R.; Bagby, W.C. The geology and origin of Carlin-type gold deposits. In Gold Metallogeny and Exploration; Foster, R.P., Ed.; Blackie and Son Ltd.: Glasgow, UK, 1990; pp. 210-248.

110. Xiao, T.; Yang, F.; Li, S.; Zheng, B.; Ning, Z. Thallium pollution in China: A geo-environmental perspective. Sci. Total Environ. 2012, 421-422, 51-58. [CrossRef] [PubMed]

111. Haynes, W.M. (Ed.) CRC Handbook of Chemistry and Physics, 95th ed.; CRC Press/Taylor and Francis: Boca Raton, FL, USA, 2012; 2664p.

112. Eggers, M.; Research Scientist, Center for BioFilm Engineering, Montana State University, Bozeman, MT, USA, Results of Tl MS-ICP Analyses of Drinking Water Well Samples from the Crow Reservation Performed at University of New Mexico, Albuquerque, NM. Personal communication, 2 May 2016.

113. Carnotite Mineral Data. Available online: http://webmineral.com/data/Carnotite.shtml\#.WdGTZltSxdg (accessed on 26 September 2017).

114. Francevillite Mineral Data. Available online: http://webmineral.com/data/Francevillite.shtml\# .WdHTsFtSxdg (accessed on 10 October 2016).

(C) 2017 by the authors. Licensee MDPI, Basel, Switzerland. This article is an open access article distributed under the terms and conditions of the Creative Commons Attribution (CC BY) license (http:/ / creativecommons.org/licenses/by/4.0/). 